AUTARQUIA ASSOCIADA À UNIVERSIDADE DE SÃO PAULO

\title{
AUDIÊNCIA PÚBLICA PARA O LICENCIAMENTO AMBIENTAL DE INSTALAÇÕES NUCLEARES: UMA VISÃO CRÍTICA
}

Luciana Gomes Vasques

Dissertação apresentada como parte dos requisitos para obtenção do Grau de Mestre em Ciências na Área de Tecnologia Nuclear - Materiais

Orientador:

Prof. Dr. Afonso Rodrigues de Aquino 
INSTITUTO DE PESQUISAS ENERGÉTICAS E NUCLEARES

Autarquia associada à Universidade de São Paulo

\section{AUDIÊNCIA PÚBLICA PARA O LICENCIAMENTO AMBIENTAL DE INSTALAÇÕES NUCLEARES: UMA VISÃO CRÍTICA}

Luciana Gomes Vasques

Dissertação apresentada como parte dos
requisitos para obtenção do Grau de
Mestre em Ciências na Área
de Tecnologia Nuclear-Materiais

Orientador:

Prof. Dr. Afonso Rodrigues de Aquino

Versão Corrigida

Versão Original disponível no IPEN

São Paulo

2016 


\section{AGRADECIMENTOS}

Sobretudo à DEUS por me mostrar que a fé na vitória tem que ser inabalável;

Ao Professor Afonso Rodrigues de Aquino pela paciência, confiança, imensa sabedoria e conhecimento, estímulo e auxílio no desenvolvimento desse trabalho;

A todos os professores e profissionais que participaram desse processo desafiador.

Ao meu pai Manuel Gomes Vasques pelo apoio, incentivo, admiração e disposição para o auxílio em todos os momentos;

À minha melhor amiga e eterna "madrasta" Nilza Cristina Conceição pelo carinho, pela fé, confiança e crença absoluta na minha capacidade de realização;

À minha mãe Ivone Magro e filha Marina Vasques pela paciência, compreensão e minha "ausência" no período de elaboração desse trabalho;

Aos amigos Margarida Szurkalo pela indicação e apoio, Aryel Heitor e Márcia Dias pela união e bons momentos sempre, Marcos Rodrigues pela força e conhecimento e a todos os outros não citados a fim de não cometer injustiças, mas, que também fizeram parte dessa etapa tão importante para minha vida e formação acadêmica. 
"A única verdadeira sabedoria está em saber que você não sabe nada". 


\title{
AUDIÊNCIA PÚBLICA PARA O LICENCIAMENTO AMBIENTAL DE INSTALAÇÕES NUCLEARES: UMA VISÃO CRÍTICA
}

\author{
Luciana Gomes Vasques
}

\section{RESUMO}

O uso intensivo da tecnologia nuclear contribuiu para o aumento das preocupações com as questões ambientais e sua segurança, acabando por despertar o interesse em toda sociedade. No Brasil, as atividades nucleares são regulamentadas pelo Conselho Nacional do Meio Ambiente (CONAMA). A primeira resolução CONAMA, n 001/1986, estabeleceu que as atividades nucleares deveriam ser licenciadas pela agência ambiental brasileira, ou seja, pelo Instituto Brasileiro do Meio Ambiente e dos Recursos Renováveis (IBAMA), independentemente da obrigatoriedade do licenciamento pela Comissão Nacional de Energia Nuclear (CNEN). No licenciamento é preciso elaborar o Estudo de Impacto Ambiental (EIA), um conjunto de estudos realizados por especialistas de diversas áreas, com dados técnicos detalhados, e o Relatório de Impacto Ambiental (RIMA), que deve apresentar as conclusões do EIA de forma objetiva e adequado à sua compreensão. O principal mecanismo de participação direta da população na proteção da qualidade ambiental é a audiência pública. Ela tem como finalidade expor ao público as características do projeto e o conteúdo do EIA/RIMA. Durante a audiência pública os participantes podem fazer perguntas sobre o empreendimento e tirar dúvidas sobre como se dará o licenciamento. As audiências públicas são organizadas pelos empreendedores, consoante diretrizes emitidas pelo IBAMA. Sendo a audiência pública a etapa do licenciamento mais propícia a subjetividades, este trabalho é uma contribuição para a área a partir da avaliação crítica do modelo de audiência pública, atualmente adotado, para o licenciamento ambiental de instalações nucleares. 


\title{
PUBLIC HEARING FOR ENVIRONMENTAL PERMIT OF NUCLEAR FACILITIES: A CRITICAL VIEW
}

\author{
Luciana Gomes Vasques
}

\begin{abstract}
The intense use of nuclear technology has contributed an increase in concerns about environmental issues and safety, promoting the interest of society in the issue. In Brazil, nuclear activities are regulated by the Brazilian Environmental Council - CONAMA. The first CONAMA's resolution no 001/1986, establishes that the nuclear activities must be licensed by the Brazilian environmental agency, i.e., the Brazilian Institute of Environment and Renewable Resources - IBAMA, regardless of compulsory licensing by Brazilian Commission of Nuclear Energy CNEN. Licensing is necessary to prepare the Environmental Impact Study - EIA, a set of studies performed by specialists from several areas with technical data in details, and the Environmental Impact Report - RIMA must reflect the EIA conclusions. This should be presented objectively and adequate to its understanding. The main mechanism of direct participation of the population in protecting the environmental quality is the public hearing. It aims to expose to the public the project characteristics and EIA and RIMA. During the Public Hearing, the participants may ask questions on enterprise and clarify doubts about how the licensing is. Public hearings are organized by entrepreneurs, according to guidelines issued by IBAMA. Whereas the public hearing is the most favorable licensing stage of the subjectivities, this study is a contribution to the area from the critical evaluation of the public hearing model currently adopted for the environmental licensing of nuclear.
\end{abstract}

Keywords: Public Hearing, Licensing, Environmental Management 


\section{SUMÁRIO}

Página

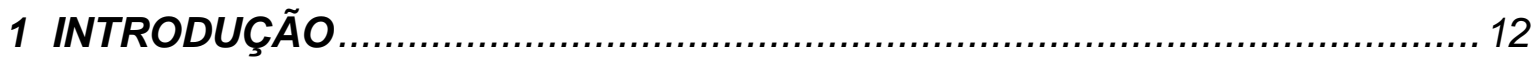

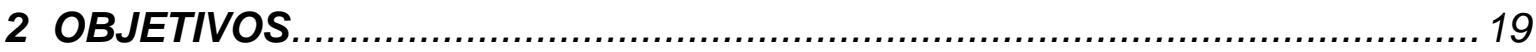

3 INSTALAÇÕES NUCLEARES E RADIOATIVAS ....................................... 20

3.1 Ciclo do Combustível Nuclear (CCN) ...................................................20

3.1.1 Etapas do Ciclo do Combustível Nuclear ................................................21

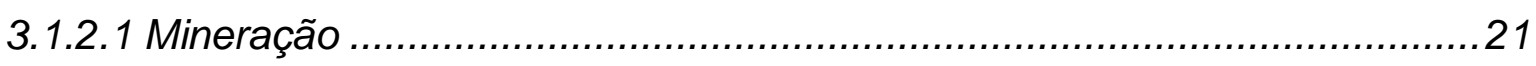

3.1.2.2 Concentração do minério e purificação do $U$.......................................21

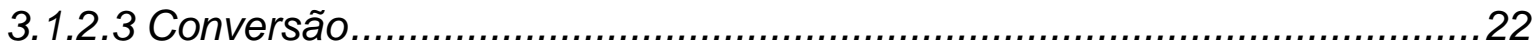

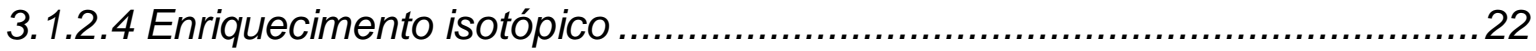

3.1.2.5 Fabricação do combustível nuclear......................................................23

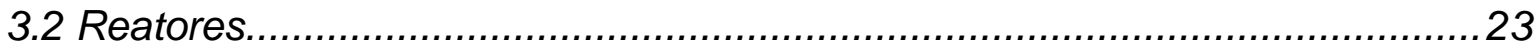

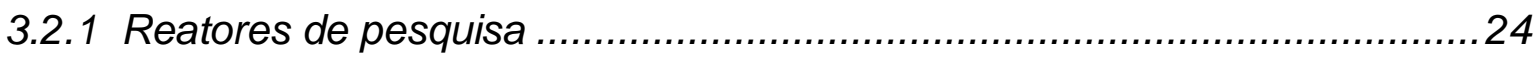

3.2.2 Reatores de potência ..................................................................26

3.2.2.1 Reator PWR ............................................................................ 26

3.3 Repositório de Rejeitos Radioativos ...................................................... 28

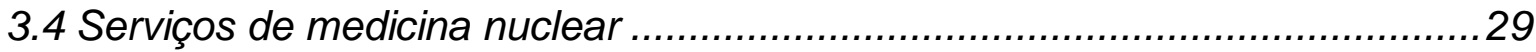

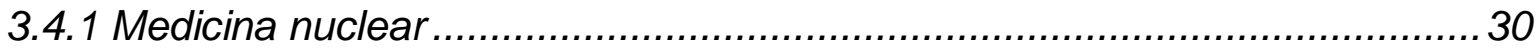

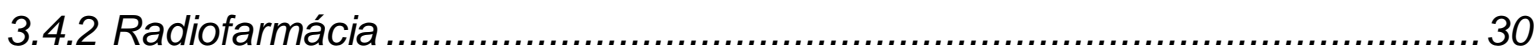

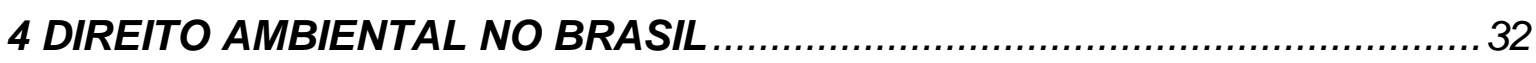

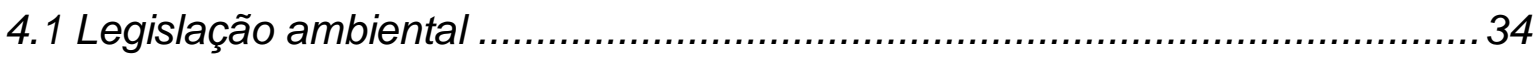

5 LICENCIAMENTO AMBIENTAL DE INSTALAÇÕES NUCLEARES .............. 36

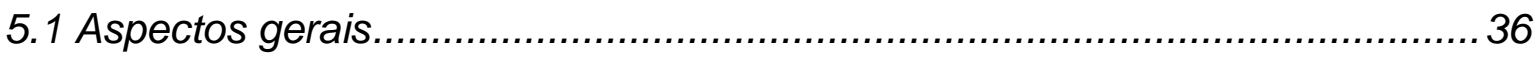

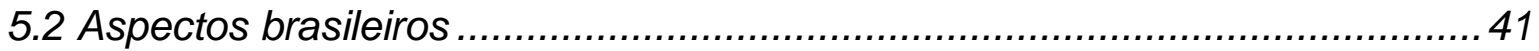

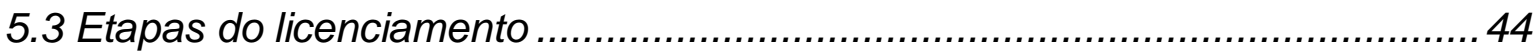

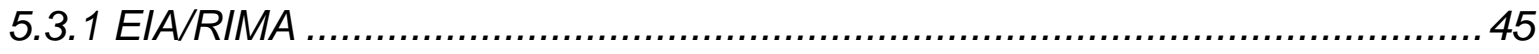

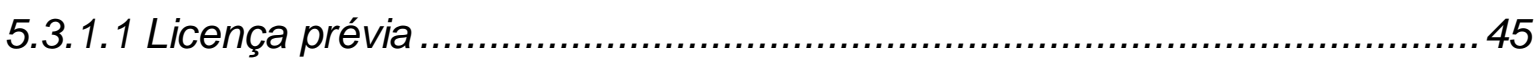




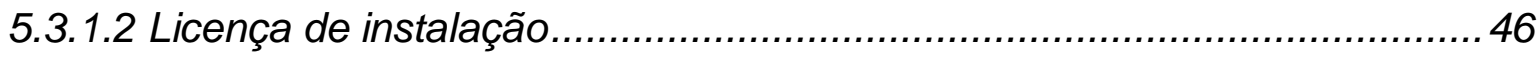

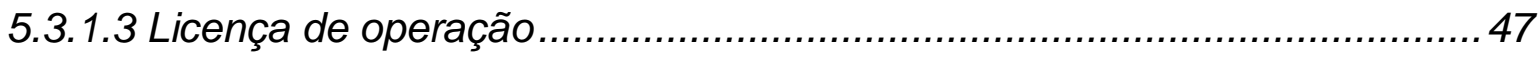

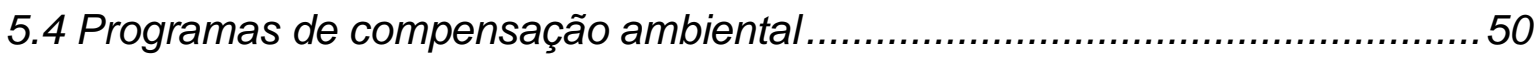

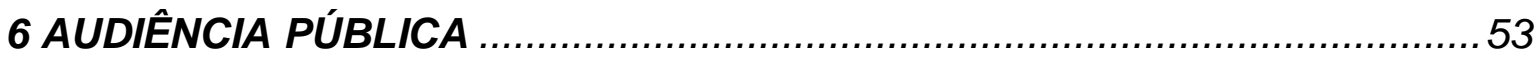

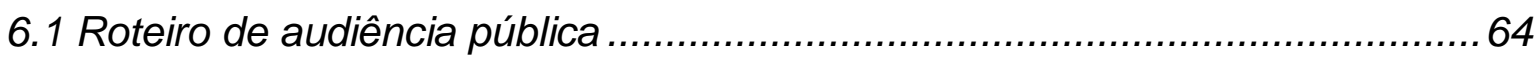

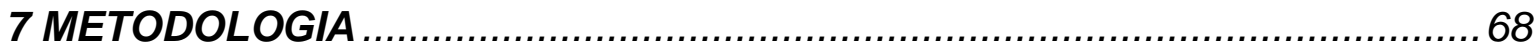

8 RESULTADOS E DISCUSSÃO

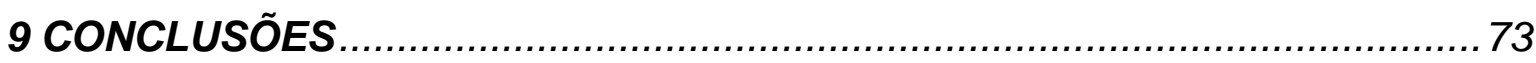

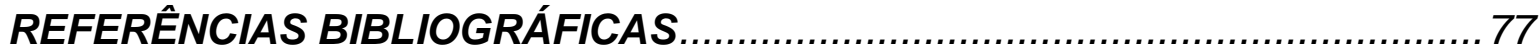




\section{LISTA DE TABELAS}

TABELA 1. Reatores Nucleares de Pesquisa no Brasil ....................................... 25

TABELA 2. Órgãos componentes do SISNAMA (Sistema Nacional do Meio

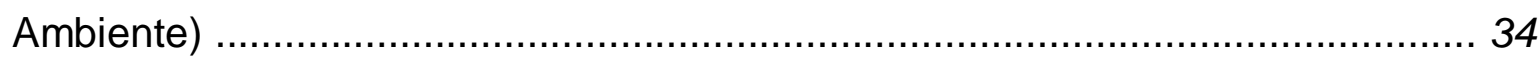

TABELA 3. Prazos de validade das licenças ambientais ..................................... 44

TABELA 4. Tabela de fórmulas e cálculos referentes ao impacto ambiental .........49

TABELA 5. Lista de tarefas e responsabilidade para a preparação das audiências públicas referente a empreendimentos causadores de impacto ambiental............ 62

TABELA 6. Publicidade nas etapas do Licenciamento Ambiental ....................... 65

TABELA 7. Etapas para condução de audiências públicas em Quebec, Canadá ..65 


\section{LISTA DE FIGURAS}

FIGURA 1. Países que utilizam a energia nuclear ........................................13

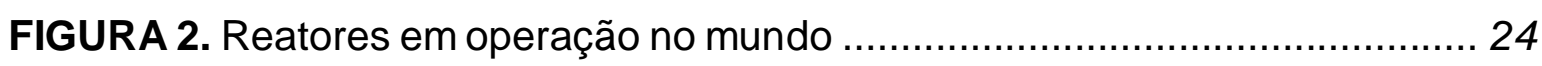

FIGURA 3. Reator do tipo PWR (Pressurized Water Reactor) …........................ 27

FIGURA 4. Diagrama esquemático para obtenção da Licença Prévia .................. 46

FIGURA 5. Diagrama esquemático para obtenção de Licença de Instalação ...... 47

FIGURA 6. Diagrama esquemático para a obtenção da Licença de Operação .... 48

FIGURA 7. Etapas do processo de Licenciamento Ambiental no Brasil ............... 50

FIGURA 8. Etapas do licenciamento nos Estados Unidos até as audiências públicas

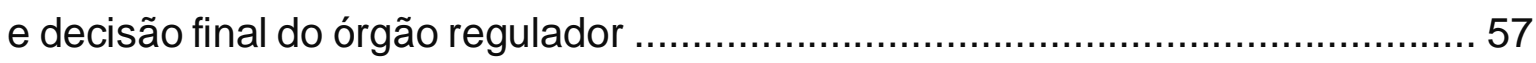

FIGURA 9. Conjunto de operações envolvidas na transmissão de informações para a audiência, desde sua origem até sua utilização ............................................ 61

FIGURA 10. Etapas do processo de audiências públicas no Brasil ..................... 67 FIGURA 11. Contribuições para o modelo de audiência pública para instalações nucleares no Brasil segundo o IBAMA ..........................................................76 


\section{LISTA DE ABREVIATURAS}

AIA - Avaliação de Impacto ambiental

AIEA - Agência Internacional de Energia Atômica

CESP - Companhia Estadual de Energia Elétrica do Estado de São Paulo

CNEN - Comissão Nacional de Energia Nuclear

CNPq - Conselho Nacional de Desenvolvimento Científico e Tecnológico

CNUMAD - Conferência das Nações Unidas sobre o Meio Ambiente e o Desenvolvimento

CONAMA - Conselho Nacional de Meio Ambiente

CTR - Cadastro Técnico Federal

EIA - Estudo de Impacto Ambiental

EPA (Environmental Protection Agency) - Agência de Proteção ambiental

IBAMA - Instituto Brasileiro do Meio Ambiente e dos Recursos Naturais Renováveis

IEA - Instituto de Energia Atômica

INEA - Instituto Estadual Ambiental

IPEN - Instituto de Pesquisas Energéticas e Nucleares

LI - Licença de Instalação

LO - Licença de Operação

LP - Licença Prévia

LWR (Light Water Reactor) - Reator de água leve

NORM (Naturally Occurring Radioactive Materials) - Materiais radioativos de origem natural

ONG's - Organização não Governamental

PBA - Projeto Básico Ambiental

PCA - Plano de Controle Ambiental 
PNMA - Política Nacional de Meio Ambiente

PRAD - Plano de Recuperação de Áreas Degradadas

PWR (Pressurized Water Reactor) - Reator de água pressurizada

RADA - Relatório de Avaliação de Desempenho Ambiental do Sistema de Controle e demais Medidas Mitigadoras

RCA - Relatório de Controle Ambiental

RIMA - Relatório de Impacto Ambiental

RMB - Reator Multipropósito Brasileiro

SISNAMA - Sistema Nacional de Meio Ambiente

SMN - Serviço de Medicina Nuclear

SNUC - Sistema Nacional de Unidades de Conservação

TENORM (Technologically Enhanced Naturally Occurring Radioactive Materials) Materiais radioativos de origem natural e concentrados tecnologicamente.

U.S. NRC (United States Nuclear Regulatory Comission) - Comissão Reguladora Nuclear dos Estados Unidos 


\section{INTRODUÇÃO}

Wilhelm G. Röntgen descobriu os raios X no ano de 1895 abrindo as portas para que em 1898, outros pesquisadores como Antoine $\mathrm{H}$. Becquerel viesse a descobrir a radioatividade, enquanto que, em 1900 Ernst Rutherford e o casal Pierre e Marie Curie identificassem as partículas alfa e beta ( $\alpha$ e $\beta$ ). Nesse mesmo ano Paul Villard, ainda no mesmo ano, identificou uma forma de radiação eletromagnética que denominou como radiação gama $(\gamma)$.

Cada tipo de radiação possui características próprias, as radiações $\alpha$ são núcleos do átomo de hélio, constituídos de dois prótons e dois nêutrons ligados por forças nucleares, é a mais pesada, de menor alcance e pouco penetrante, mas se a fonte emissora for ingerida, pode causar severos danos ao organismo. As radiações $\beta$, elétrons e pósitrons, são mais penetrantes que a $\alpha$ e os raios $\gamma$, ondas eletromagnéticas como as ondas de rádio, luz e raios- $X$, necessitando para sua blindagem do chumbo, concreto, aço ou terra.

No acidente radioativo de Goiânia em 1987, onde as pessoas sofreram queimaduras ao espalharem o pó azul de Césio ( ${ }^{137} \mathrm{Cs}$ ) pelo corpo e outras consequências graves devido ao tempo de contato com esse radioisótopo.

Em 1934, primeiramente Irène Curie e Frédéric Joliot produziram um radioisótopo inexistente na natureza, bombardeando uma folha de alumínio com partículas $\alpha$. Com essas descobertas, as radiações e emissões nucleares, tanto naturais quanto artificiais passaram a ser utilizadas desenfreadamente e estudadas com mais afinco do ponto de vista tecnológico, e mais especificamente para as aplicações industriais (Tébéka e Hallwass, 2007, p.1).

Com a descoberta da energia nuclear, observou-se que ela seria liberada em sua maior parte na forma de calor, como ocorre na divisão do núcleo de um átomo pesado, como no Urânio $\left({ }^{235} \mathrm{U}\right)$, em dois menores, quando atingido por um nêutron, originando o que é chamado de fissão nuclear, principal processo de geração de energia nuclear e, que resulta, além dos núcleos menores, dois a três nêutrons igualmente ao nêutron que causou a fissão atingindo outros núcleos 
de Urânio ( $\left.{ }^{235} U\right)$. As reações de fissão ocorrem em frações de segundos resultando em grande liberação de energia sob a forma de calor, se denominando, reação em cadeia. Essas reações controladas é que são usadas nos reatores nucleares para a geração de energia elétrica.

A energia elétrica é de fundamental importância para o desenvolvimento e atendimento das necessidades humanas, melhorando inclusive, a qualidade de vida da população. Atualmente, no mundo, aproximadamente trinta países utilizamse da energia nuclear para a geração de energia elétrica conforme mostra a Fig. 1.

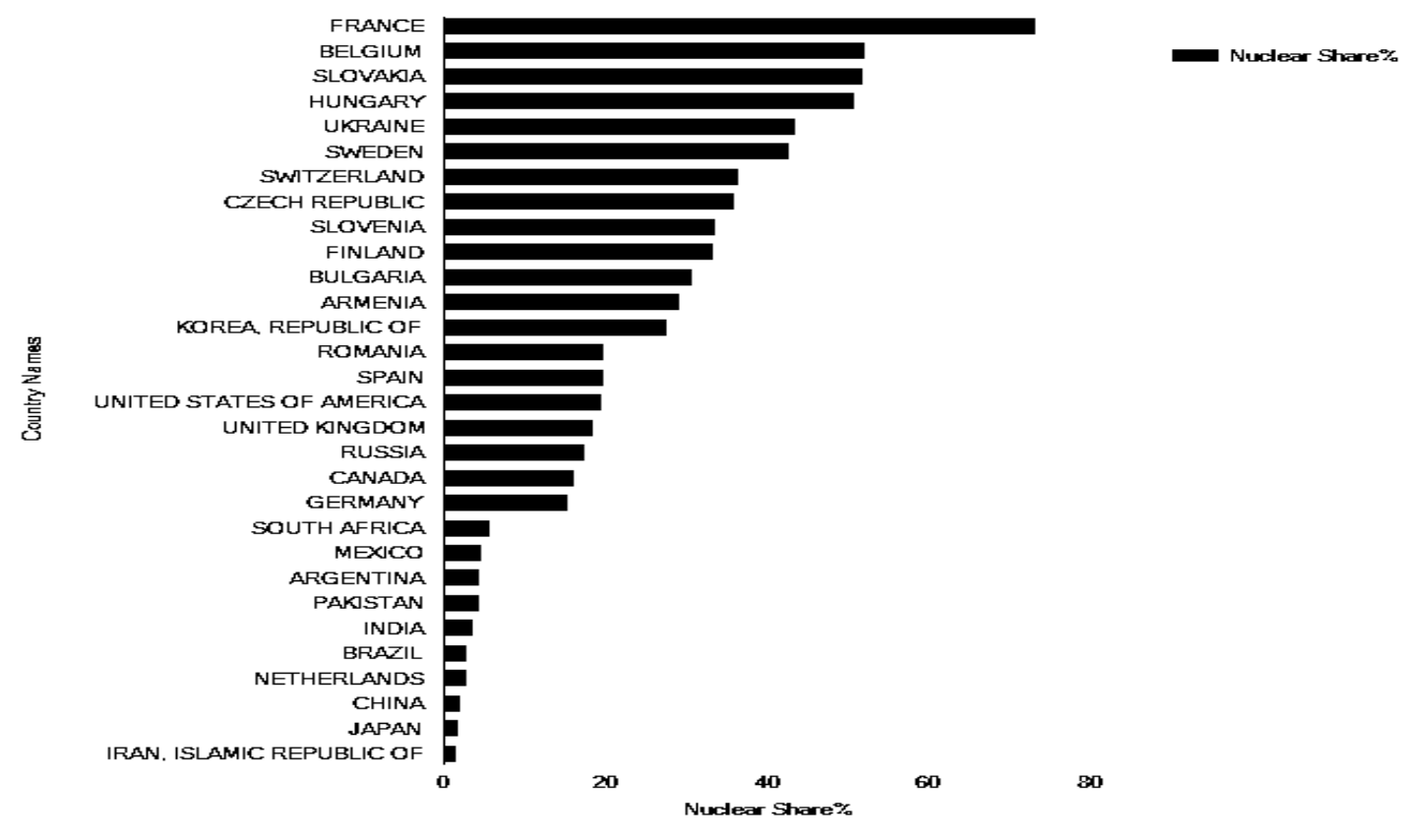

FIGURA 1. Países que utilizam a energia nuclear Fonte: IAEA, 2013

Para Guimarães e Mattos (2010) o acesso aos serviços modernos de energia, contribuem para o crescimento econômico, de renda familiar, leva a substituição de combustíveis tradicionais como o carvão, madeira, querosene e outros por combustíveis mais avançados como gás de petróleo, naturais e eletricidade, principalmente a proveniente da energia nuclear.

A energia nuclear há tempos vem despertando o interesse do mundo todo já que pode oferecer uma alternativa ao uso dos combustíveis fósseis, entretanto, seu uso ainda gera insegurança. Durante a fissão nuclear (produtos de fissão) radioativos, e a persistente associação quanto à utilização da mesma tecnologia para fins bélicos. 
Liderado pelo físico italiano Enrico Fermi, o primeiro reator nuclear começou a ser construído em novembro de 1942 em um espaço modesto de 18 metros de comprimento, 9 de largura e 8 de altura debaixo da arquibancada do estádio de atletismo da Universidade de Chicago.

No Brasil, o primeiro reator nuclear de pesquisas, o IEA-R1, foi construído no Instituto de Energia Atômica, atual Instituto de Pesquisas Energéticas e Nucleares, localizado no campus da Universidade de São Paulo, depois vieram o TRIGA (Training, Research, Isotopes Production, General Atomics), Mark-1 do Instituto de Pesquisas Radioativas - IPR (atual CDTN), localizado no campus da Universidade Federal de Minas Gerais (Pampulha) em Belo Horizonte e, no campus da Universidade Federal do Rio de Janeiro, na llha do Fundão, o ARGONAUTA.

$\mathrm{Na}$ década de 60 , em Pernambuco teve início um movimento para desenvolvimento de tecnologia nuclear no Estado onde foi criado um grupo de trabalho para estudar a viabilidade de aquisição, instalação e funcionamento de um reator de pesquisas no campus universitário. Em 1964, houve a construção do Centro Nuclear no campus da UFPE, e em 1968 durante a reforma da Universidade, foi criado o DEPARTAMENTO DE ENERGIA NUCLEAR - DEN.

Em 1988, entra em operação o IPEN/MB-01, o primeiro reator nuclear genuinamente brasileiro, resultado de uma parceria entre o IPEN e a Marinha do Brasil (Tavares, 2012).

No ano de 1971 o Governo brasileiro comprou um reator de água pressurizada (PWR), fabricado pela Westinghouse e, em 1972 assinou o contrato da Usina Angra I e iniciadas as obras civis para sua construção, em Angra dos Reis na praia de Itaorna e, em junho de 1975, foi assinado um acordo nuclear com a Alemanha onde previa-se a construção de oito usinas, mas, atualmente foram construídas apenas Angra II em 2001, e Angra III em fase de licença de operação, com previsão de inauguração somente para 2018.

Em 26 de abril de 1986, na Ucrânia, ocorreu um dos acidentes nucleares mais graves da história na central nuclear de Chernobyl. Um erro nos testes provocou a explosão em um dos reatores RBMK-1000 provocando a liberação de toneladas de material radioativo, mais de 40 radionuclídeos, entre eles o lodo ( $\left.{ }^{131} \mathrm{I}\right)$, o Césio $\left({ }^{137} \mathrm{Cs}\right)$ e o Estrôncio $\left({ }^{90} \mathrm{Sr}\right)$, havendo a formação de uma nuvem radioativa que com o vento se espalhou por vários países da Europa (Steinhauser et al., 
2014). Algumas pessoas morreram, enquanto outras sofreram queimaduras graves e outras lesões (Ishiguro, 2002; Xavier et al., 2007).

Segundo Veiga (2012), um acidente não menos grave em Goiânia, ocorrido no Brasil em 13 de setembro de 1987, mostrou as autoridades a importância na tomada de decisões mais seguras para lidar com a energia nuclear. Uma cápsula contendo Césio ( ${ }^{137} \mathrm{Cs}$ ) foi violada por sucateiros após ser encontrada nos escombros do Instituto Radiológico de Goiânia. Esse material contaminou não só as pessoas que tiveram acesso ao material como também as residências e o ambiente. Após ser notificada, a Comissão Nacional de Energia Nuclear (CNEN) montou uma estratégia de descontaminação que contou com a participação de aproximadamente 730 trabalhadores para auxiliar na evacuação e demolição de residências e na reparação de outros locais.

No Japão, em 2011, a tragédia nas centrais nucleares de Fukushima Daiichi e Fukushima Daini desencadeadas por um terremoto, seguido de um tsunami no mar, levou a destruição de três reatores que liberaram material radioativo na atmosfera. Os muros de contenção apresentavam $10 \mathrm{~m}$, mas o tsunami não previsto ultrapassou os $14 \mathrm{~m}$ e invadiu a usina (Steinhauser et al., 2014).

É importante diferenciar os acidentes nucleares como os ocorridos nos reatores das usinas e os acidentes radioativos como o de Goiânia e os causados por fenômenos ambientais, no caso, o de Fukushima, no Japão. Como consequência desses acontecimentos, houve um aumento na desconfiança pública em relação à adoção da energia nuclear para geração de eletricidade. O porcentual geral dos que se declararam contrários às centrais nucleares subiu de $28 \%$ para $47 \%$, com $40 \%$ mantendo esse apoio. Em outros países que fazem uso da energia nuclear como a França, a rejeição passou de 31\% para 41\%, na Alemanha de $64 \%$ para $72 \%$, na Índia, de $17 \%$ para $35 \%$, na China de $16 \%$ para 30\%, e no Brasil de 49\% para 54\% (Marques, 2012; Veiga, 2011).

As lições deixadas com os acidentes influenciaram os projetos para o desenvolvimento de reatores com criteriosos princípios de segurança.

Atualmente, encontra-se em fase de projeto e licenciamento o Reator Multipropósito Brasileiro (RMB). O empreendimento será instalado em terreno doado pela Marinha do Brasil à Comissão Nacional de Energia Nuclear, no Centro Experimental de Aramar em Iperó - São Paulo, cujo objetivo de sua construção é 
possibilitar ao país uma infraestrutura estratégica e autossuficiência para a produção de radioisótopos e fontes radioativas para a saúde, indústria, agricultura e meio ambiente; realizar testes de irradiação de materiais e combustíveis nucleares e realizar pesquisas científicas e tecnológicas com feixes de nêutrons (RELATÓRIO DE IMPACTO AMBIENTAL, 2013, ÓRBITA, 2014).

No caso das usinas de Angra, o reator adotado foi o reator de potência do tipo PWR (reator a água pressurizada) que segue rigorosos princípios de segurança, onde o combustível utilizado é o urânio enriquecido isotopicamente em ${ }^{235} \mathrm{U}$. Nos reatores de pesquisa ou de propulsão, o enriquecimento pode variar bastante. A vantagem do reator PWR é que o aquecimento excessivo da água em seu interior diminui o aproveitamento, ocasionando uma redução da frequência de novas fissões, faz a temperatura da água também diminuir, e consequentemente, as chances de um acidente nuclear.

Para a obtenção do urânio, ocorrem várias etapas chamadas de ciclo do combustível (CCN) como a extração do minério do solo, a concentração do minério e purificação do $U$, etapa também conhecida como beneficiamento, conversão, enriquecimento isotópico e a fabricação de pastilhas a partir da compactação do pó e finalmente a montagem dos elementos combustíveis, quando se colocam as pastilhas em cilindros metálicos que irão formar os elementos combustíveis do núcleo do reator (Gonçalves e Almeida, 2005, p. 42).

É importante ressaltar que a energia nuclear tem ainda aplicação em outros setores como na desinfestação e conservação de obras de arte, geração de energia e propulsão de navios, na arqueologia, com técnicas de datação com a utilização do carbono-14, na Química, em determinados métodos analíticos e na preservação de alimentos por irradiação.

No IPEN, em 1959, foram iniciadas a produção de radioisótopos que contém um ou mais radionuclídeos, utilizados na produção de radiofármacos de interesse principalmente na área médica (Araújo, E. et al., 2008).

$\mathrm{Na}$ medicina atual, até que haja o desenvolvimento de outras técnicas, dispensar o uso de radiofármacos no diagnóstico e tratamento de doenças como o câncer torna-se quase impossível.

Em situações de risco, como a atual epidemia de dengue, zika vírus e febre chikungunya, a energia nuclear é importante pela sua capacidade de esterilização do mosquito Aedes aegypti. Nesse processo, os machos do mosquito 
seriam expostos a raios $\mathrm{X}$ ou $\gamma$, o que tornaria seu esperma estéril e, liberados no meio ambiente, cruzariam com as fêmeas da mesma espécie cujos ovos nunca se desenvolveriam, diminuindo, portanto, o número de insetos sem afetar o ecossistema de determinadas regiões (IPEN, 2016).

As décadas de 70 e 80 também foram marcadas por importantes acontecimentos, principalmente ao que se refere a empreendimentos causadores de grande impacto ambiental, como a construção da Transamazônica e da hidrelétrica de Itaipú que levaram a desastres ambientais. A importância e o vulto das obras realizadas nesse período, contribuíram para que a degradação ambiental se transformasse em um dos temas mais discutidos na atualidade, uma problemática que não será resolvida com o auxílio do Direito Ambiental, mas sim, diminuída ou minimizada com a sua aplicação (Barbosa, 2011).

Deve-se levar em consideração as particularidades e os aspectos a serem abordados no licenciamento ambiental e no licenciamento nuclear, onde este último prevê não só as atividades comuns de uma instalação nuclear, como os riscos oferecidos por tais instalações, assim como os métodos de proteção, de barreira e segurança.

Entre 1974 e 1981, o licenciamento das instalações nucleares era de responsabilidade da CNEN (artigo $7^{\circ}$ da Lei n. 6.874/7) e pelo órgão estadual de meio ambiente. Entre 1981 e 1989, o licenciamento era de exclusiva competência da CNEN, como preconiza a Lei n. 6.938, de 31 de agosto de 1981 (Lei da Política Nacional do Meio Ambiente - PNMA) que define a competência do Poder Executivo Federal para realizar o licenciamento de instalações nucleares e, a partir de 1989, o licenciamento ambiental passa então ao IBAMA, ficando a CNEN responsável apenas pelo licenciamento nuclear (INB, 2013).

A criação da Resolução CONAMA 001/86 estabeleceu critérios para o licenciamento ambiental, inclusive com a obrigatoriedade de realização das audiências públicas, e, além disso, listou uma série de atividades que devem ser elaboradas e submetidas para a produção do EIA (Estudo de Impacto Ambiental) e seu respectivo RIMA (Relatório de Impacto Ambiental), entre estas, as instalações nucleares.

Após a elaboração do EIA e do RIMA), esses documentos devem ficar à disposição da população e de órgãos interessados para que sejam feitos comentários e posteriormente sejam realizadas audiências públicas para discussão 
desses relatórios, como dispõe a Resolução de oㅜ 9 de 1987 (CONAMA 009/87). Caso as audiências públicas não sejam realizadas, a licença do órgão competente não terá validade.

As audiências públicas são reuniões organizadas, com o objetivo de levar e divulgar para o público, informações sobre o EIA e o RIMA e conta com a participação de pessoas, autoridades e organizações ambientais ou não que tenham interesse ou responsabilidades em relação aos temas abordados.

Para a realização dessas audiências públicas são considerados alguns aspectos importantes como a publicação em Diário Oficial e a divulgação em jornais locais e regionais, e, onde os representantes do empreendedor devem estar preparados para a apresentação sobre o empreendimento e para a audiência pública (Roteiro de Audiência Pública, 2009).

A Constituição Federal Brasileira de 1988, em seu artigo 225, defende que é dever do poder público e da coletividade a proteção do meio ambiente, ou seja, das organizações não-governamentais, dos sindicatos, das indústrias, dos comerciantes, dos agricultores, cidadãos brasileiros e estrangeiros residentes no país.

O pouco conhecimento sobre a energia nuclear e os mitos em decorrência do que é transmitido pela mídia, faz a maioria das pessoas ainda acreditar que a energia nuclear deva permanecer apenas como uma alternativa desde que os rejeitos radioativos resultantes sejam regidos de forma segura.

Em países em constante crescimento como o Brasil, mesmo com grande potencial hidrelétrico, a busca por novas fontes de geração de energia elétrica, como a nuclear, é de fundamental importância, uma vez que o crescimento industrial está acompanhado do aumento populacional, ocasionando uma demanda energética crescente. Além disso, em um país de dimensões continentais o regime de águas sofre grande variação sazonal, o que exige medidas de precaução.

Dessa forma, é de fundamental importância o reconhecimento da aplicabilidade e dos benefícios da energia nuclear e das instalações nucleares para suprir as necessidades da sociedade em vários aspectos. 


\section{OBJETIVOS}

Esse trabalho tem como objetivo avaliar o modelo de audiências públicas atualmente adotado pelo IBAMA, suas peculiaridades, falhas e necessidades visando facilitar o licenciamento ambiental de instalações nucleares;

Apresentar sugestões que possibilitem a diminuição dos custos para o empreendedor e prazos para concessão das licenças para instalações nucleares;

Ampliar a participação do público interessado e interessante nas audiências, aumentando a legitimidade das mesmas;

Facilitar o acesso e propiciar uma melhora na compreensão das audiências, através da intensificação do uso das mídias sociais da atualidade. 


\section{INSTALAÇÕES NUCLEARES E RADIOATIVAS NO BRASIL}

Entende-se por instalações nucleares os locais, reatores ou usinas onde são produzidos, processados, reprocessados, utilizados, manuseados ou estocados materiais nucleares. Tratando-se de reatores nucleares, essas instalações possuem uma licença de operação em torno de 40 anos, cuja tendência é se estender por 20 anos ou mais, um fenômeno que não fica restrito apenas a países como o Brasil (Deutch et al., 2003).

As instalações radioativas por sua vez, são estabelecimentos como os hospitais e unidades de radioterapia onde ocorre a produção, utilização, transporte ou armazenamento de fontes de radiação, nestas, estão incluídas as radiofarmácias (Santini, 2011).

\subsection{Ciclo do Combustível Nuclear (CCN)}

O ciclo do combustível nuclear é o conjunto de etapas para a fabricação do combustível nuclear que consiste na fabricação, irradiação em reatores nucleares, armazenamento temporário ou definitivo após irradiação. É um processo complexo que vai desde a mineração até o gerenciamento e manejo de rejeitos radioativos.

Existem duas opções para o ciclo do combustível: o ciclo aberto, onde os elementos combustíveis passam pelo reator uma vez e não ocorre o reprocessamento do ${ }^{235} \mathrm{U}$ e do ${ }^{239} \mathrm{Pu}$, ou seja, esses elementos não são reutilizados, e o ciclo fechado onde os elementos combustíveis como o ${ }^{235} \mathrm{U}$ e o ${ }^{239} \mathrm{Pu}$ são reciclados em uma instalação de reprocessamento.

A adoção de um programa de monitoração ambiental nesses locais também é importante porque permite o controle do material radioativo e a avaliação da potencial exposição do homem à radiação, que devem seguir os regulamentos e limites operacionais (Chmielewski, 2011). 


\subsubsection{Etapas do Ciclo do Combustível Nuclear (CCN)}

As etapas do CCN vão desde o processo de mineração até o depósito final do elemento combustível e envolvem processos como a mineração e purificação do urânio, conversão, enriquecimento isotópico e fabricação do combustível.

\subsubsection{Mineração}

O urânio é o elemento mais amplamente distribuído na crosta terrestre e deve ser extraído e transformado em um composto que posso ser utilizado nas outras etapas do ciclo do combustível. Ele pode ser extraído utilizando-se técnicas como a mineração subterrânea com túneis escavados na terra, mineração a céu aberto, usada em corpos de minério próximo da superfície, e a lixiviação in-situ que envolve o bombeamento de uma solução lixiviadora como o ácido sulfúrico, ácido nítrico ou carbonato (Santos, 2014).

\subsubsection{Concentração do minério e purificação do U}

Etapa também conhecida como beneficiamento do urânio e que envolve a britagem, a lixiviação, a extração com solvente e a produção do yellowcake. Pobre em urânio, o minério é concentrado e convertido num pó amarelo seco conhecido como óxido de minério de urânio (UOC), o yellowcake (diuranato de amônio ou de sódio que calcinado dá origem ao $\left.\mathrm{U}_{3} \mathrm{O}_{8}\right)$.

O minério extraído é quebrado e moído até uma granulometria semelhante a areia fina e em seguida é realizada a lixiviação com um ácido, mais comumente, o ácido sulfúrico $\left(\mathrm{H}_{2} \mathrm{SO}_{4}\right)$ ou uma solução alcalina. Essa solução de $\left(\mathrm{H}_{2} \mathrm{SO}_{4}\right)$ é colocada em contato com uma pilha do minério já fragmentado. $A$ solução de sulfato de uranilo $\left(\mathrm{UO}_{2} \mathrm{SO}_{4}\right)$ obtida da lixiviação das pilhas, é então coletada para ser submetida a um primeiro estágio de purificação.

Após a obtenção do yellowcake existe uma etapa específica de purificação do urânio onde ele é purificado por extração com solvente, no caso uma amina terciária chamada tri-octil amina - TOA (Lainetti, 2013).

Nas diferentes etapas que compõem o ciclo do combustível, o material continua a ser purificado e em cada operação onde ocorre mudança de fase ou estado físico. 


\subsubsection{Conversão}

A conversão é a etapa que vai desde a produção de yellowcake, resultante da purificação do urânio, até a sua obtenção sob a forma gasosa, como $\mathrm{UF}_{6}$ (hexafluoreto de urânio). Essa etapa ocorre em temperaturas relativamente baixas, aproximadamente $56^{\circ} \mathrm{C}$ a $60^{\circ} \mathrm{C}$ e favorece a etapa seguinte, $\mathrm{O}$ enriquecimento (Santos, 2014).

Existem duas rotas possíveis para o processo de conversão, a via úmida onde a fase de purificação ocorre nas primeiras etapas do beneficiamento, pela extração por solventes e a via seca, onde o concentrado do minério, ainda na forma impura, reage com flúor, obtendo-se a purificação por destilação fracionada. Como o flúor forma compostos com as impurezas com propriedades diferentes das do UF6 a purificação é obtida por destilação seletiva, sem a presença de fases líquidas, apenas fases sólida e gasosa.

\subsubsection{Enriquecimento isotópico}

O enriquecimento do urânio é determinado pelo processo físico/químico de diminuição da porcentagem do isótopo ${ }^{238} \mathrm{U}$ de urânio natural, e o consequente aumento da concentração do isótopo ${ }^{235} \mathrm{U}$. É uma das fases do ciclo do combustível nuclear importante para fabricação de elementos combustíveis para reatores de pesquisa e/ou PWR (água natural/urânio enriquecido), utilizados nas usinas de Angra.

Foram desenvolvidos vários processos de enriquecimento isotópico de ${ }^{235} \mathrm{U}$, entre eles o do Jato Centrífugo, a Ultracentrifugação e a Difusão Gasosa, (Chmielewski, 2011).

O urânio sob a forma química de $\mathrm{UF}_{6}$, não é apropriado para a fabricação do combustível, sendo necessária uma transformação chamada de reconversão para o $\mathrm{UO}_{2}$.

O Brasil domina três rotas para obtenção do combustível nuclear sendo, a reconversão por meio de hidrólise, reconversão de $\mathrm{UF}_{6}$ a UF 4 (processo parede quente), adequado para a fração empobrecida em ${ }^{235} \mathrm{U}$, uma etapa intermediária na fabricação de urânio metálico e a reconversão via tricarbonato de amônio e uranilo - TCAU (o TCAU é seco e reduzido com $\mathrm{H}_{2}$ para a obtenção do $\mathrm{UO}_{2}$ ), processo desenvolvido e adotado pelo IPEN para fabricação dos combustíveis a 
base de $\mathrm{UO}_{2}$ (Aquino, 2012). $\mathrm{O}$ aumento da massa crítica de um material físsil, a criticalidade é um fator que se sobressai durante as fases de reconversão.

\subsubsection{Fabricação de combustível nuclear}

De acordo com Santos (2014), após o enriquecimento do urânio, o UF 6 é convertido em $\mathrm{UO}_{2}$ com o qual são produzidas pastilhas. As pastilhas de dióxido de urânio são colocadas em tubos de uma liga metálica especial (zircaloy), denominados varetas combustíveis, onde 235 varetas compõem esse elemento combustível. Após a fabricação do elemento combustível, o mesmo é instalado no núcleo de reator, dando início ao processo de geração de energia nuclear. Durante a vida útil das usinas, que varia de 40 a 60 anos, são feitas recargas do combustível em intervalos compreendidos entre 12 e 18 meses.

\subsection{Reatores}

Um reator nuclear é um equipamento onde se processa uma reação de fissão nuclear. O reator é, na verdade, uma central térmica, onde a fonte de calor utilizada para obtenção de energia elétrica é o urânio $\left.{ }^{235} \mathrm{U}\right)$ sem a necessidade de utilização de óleo combustível ou de carvão (CNEN, 2014).

Quando se constrói um reator térmico (nêutrons lentos), é necessário ter uma massa crítica de combustível, ou seja, material fissionável suficiente e uma disposição ideal de combustível de forma a manter a reação em cadeia.

A disposição dos absorvedores de nêutrons e das barras de controle permite manter a criticalidade (taxa de fissão constante) em operação e a subcriticalidade (taxa de fissão decrescente) em caso de desligamento, ou supercriticalidade (taxa de fissão crescente) quando inicia-se a reação também são fatores relevantes (ARIAS, 2004).

Muitos fatores influenciam no desenvolvimento e implantação de reatores nucleares, como a relação custo benefício, a segurança, as licenças e até a gestão do ciclo do combustível (Goldberg e Rosner, 2011). Ainda assim, existe um grande número de reatores nucleares no mundo, e o Brasil faz parte do seleto grupo de países possuidores desta tecnologia, conforme a Fig. 2. 


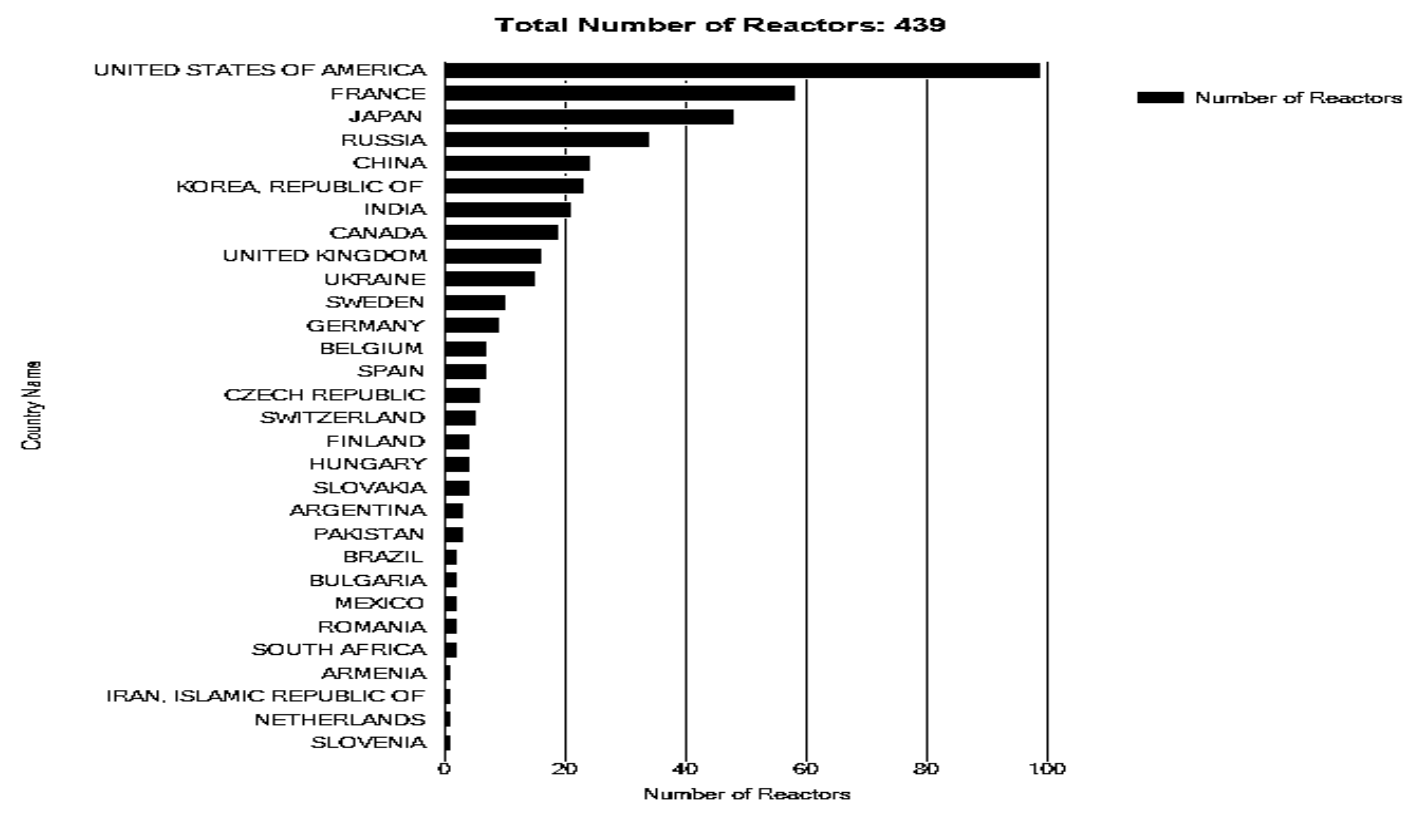

FIGURA 2. Reatores em operação no mundo Fonte: IAEA, 2015.

Existem diferentes tipos de reatores, classificados de acordo com vários critérios. Um dos mais importantes é o destino de uso (reatores de pesquisa ou de potência).

A construção do primeiro reator do mundo com potência zero foi o Chicago Pile (CP-1) sob a direção de Enrico Fermi em novembro de 1942 (Mason et al., 2013), enquanto que o primeiro reator nuclear de potência do mundo, denominado EBR-1, entrou em operação gerando 0,2MWe em dezembro de 1951, em Arco, Idaho, EUA (Terremoto, 2004).

\subsubsection{Reatores de pesquisa}

A maioria dos reatores de pesquisa iniciou suas operações em fins da década de 50 e início da década de 60 . Esses reatores são fontes de nêutrons usados na produção de radiofármacos, agricultura, indústria e pesquisas na área de energia nuclear.

Também são testados novos conceitos de reatores e combustíveis para uso em reatores de potência. Neles, o calor não é aproveitado, e sua potência gira entre $10 \mathrm{KW}$ e $100 \mathrm{MW}$. Para a produção de radioisótopos, a potência térmica destes reatores nucleares podendo ultrapassar $25 \mathrm{MW}$. 
Os principais tipos de reatores nucleares de pesquisa desenvolvidos no mundo podem ser classificados segundo as características de projeto que apresentam. Podem ser diferenciados em homogêneo líquido, tanque, piscina (o mais utilizado em todo mundo, sendo frequentemente denominado reator tipo MTR - Materials Testing Reactor), conjunto crítico seco, conjunto crítico tipo tanque, conjunto crítico homogêneo, Argonauta, TRIGA, grafite, água pesada e alto fluxo. A Tabela 1 demonstra os tipos de reatores nucleares de pesquisa existentes no Brasil.

TABELA 1. Reatores Nucleares de Pesquisa no Brasil

\begin{tabular}{|c|c|c|c|c|}
\hline Reator/Tipo & Local & Potência & Comb. & $\begin{array}{c}\text { Primeira } \\
\text { Criticalidade }\end{array}$ \\
\hline $\begin{array}{l}\text { IEA-R1 } \\
\text { (piscina) }\end{array}$ & $\begin{array}{c}\text { Instituto de Pesquisas } \\
\text { Energéticas Nucleares - } \\
\text { IPEN } \\
\text { (São Paulo, SP) }\end{array}$ & $5 \mathrm{MW}$ & $\mathrm{U}(20 \%)$ & $\begin{array}{c}16 \text { de setembro } \\
\text { de } 1957\end{array}$ \\
\hline $\begin{array}{l}\text { IPR-R1 } \\
\text { (TRIGA) }\end{array}$ & $\begin{array}{c}\text { Centro de Desenvolvimento } \\
\text { de Tecnologia Nuclear - } \\
\text { CDTN } \\
\text { (Belo Horizonte, MG) }\end{array}$ & $\begin{array}{c}100 \mathrm{KW} \\
(250 \mathrm{KW})\end{array}$ & $\mathrm{U}(20 \%)$ & $\begin{array}{l}06 \text { de novembro } \\
\text { de } 1960\end{array}$ \\
\hline ARGONAUTA & $\begin{array}{c}\text { Instituto de Energia Nuclear } \\
\text { - IEN } \\
\text { (Rio de Janeiro, RJ) }\end{array}$ & $\begin{array}{l}500 \mathrm{~W} \text { a } \\
5000 \mathrm{~W}\end{array}$ & $\underset{(19,91 \%)}{U}$ & $\begin{array}{c}20 \text { de fevereiro de } \\
1965\end{array}$ \\
\hline $\begin{array}{l}\text { IPEN/MB-01 } \\
\text { (potência } \\
\text { zero) }\end{array}$ & $\begin{array}{c}\text { Instituto de Pesquisas } \\
\text { Energéticas Nucleares - } \\
\text { IPEN } \\
\text { (São Paulo, SP) }\end{array}$ & $100 \mathrm{~W}$ & $\underset{(4,3 \%)}{U}$ & $\begin{array}{l}09 \text { de novembro } \\
\text { de } 1988\end{array}$ \\
\hline
\end{tabular}

Fonte: Silva, 2012.

Em outros países como na Austrália, o Australia's Open Pool Australian Lightwater (OPAL), inaugurado em 2007, é um reator de $20 \mathrm{MW}$ que utiliza urânio de baixo enriquecimento (LEU) com capacidade de produzir quantidades comerciais de radioisótopos. Essa capacidade associada a um design tipo piscina aberta, com uso de combustível LEU e uma ampla gama de aplicações, torna o OPAL ainda um dos melhores reatores de pesquisa do mundo.

O OPAL e mais uma série de instalações semelhantes como o Safari-1 na África do Sul, o HFR em Petten, na Holanda e o NRU em Chalk River, no Canadá desempenham um papel fundamental na sociedade, produzindo radioisótopos para o diagnóstico e tratamento do câncer e feixes de nêutrons para pesquisa de materiais (ANSTO, 2015). 


\subsubsection{Reatores de Potência}

Os reatores de potência são destacados pelo seu papel na produção de energia. Eles podem ser classificados pela energia dos nêutrons (rápidos ou térmicos); material físsil, configuração do material físsil mais o moderador; tipo de moderador (materiais com número atômico baixo: água comum, água pesada $\left(D_{2} \mathrm{O}\right.$ - deutério), grafite- carbono, berílio e óxido de berílio) e tipo de refrigerante (água leve ou pesada, gás ( $\mathrm{CO}_{2}$ ou He) e metais líquidos) (Terremoto, 2004).

Nos reatores de potência, o objetivo é a geração de energia elétrica. $O$ calor produzido pela energia das reações de fissões no combustível do reator aquece a água formando vapor e acionando as turbinas geradoras de energia elétrica.

A energia produzida em reatores nucleares varia entre dezenas de GWe a MWe. Os reatores que operam com temperatura maior são mais rentáveis em relação à geração de energia, por produzirem mais calor.

Um reator térmico de fissão é composto basicamente pelas seguintes partes: combustível (isótopos físseis e férteis); material moderador (reduz a energia cinética dos nêutrons liberados na fissão, realimentando a reação); material refrigerante (condução do calor ao local em que é produzido o vapor); refletor (reduzir o escape de nêutrons e aumentar a eficiência); blindagem (evitar escape de radiação gama e nêutrons); material de controle (absorvedores de nêutrons, podendo interromper a reação em caso de necessidade); elementos de segurança ativos (respondem a sinais elétricos) ou passivos (sensores de gravidade) e contenção de cimento ou betume circundando o reator (evitar vazamento de radiação para o exterior).

Atualmente existe uma grande variedade de reatores em uso no mundo. Observa-se que o reator predominante é o reator de água leve (LWR- Light Water Reactor), que utiliza água natural e urânio enriquecido em pastilhas de $\mathrm{UO}_{2} \mathrm{como}$ combustível. Existem dois tipos de reatores de água leve o BWR - Boiling Water Reactor) e o PWR - Pressurized Water Reactor (Bodansky, 2004), sendo esta última a opção feita pelo Brasil para reatores nucleares de potência.

\subsubsection{Reator PWR (Pressurized Water Reactor)}

No reator nuclear do tipo PWR, utilizado nas usinas de Angra I e II e adotado também em países como a França, Japão e Estados Unidos, uma das 
particularidades é que ocorre a reação de fissão em cadeia no núcleo, e o calor liberado pela reação, através de trocas com os sistemas de refrigeração primário e secundário, gera grande produção de vapor, que movimentará uma turbina e acionará um gerador elétrico produzindo energia elétrica e, a outra particularidade conferida à ele é o uso da água como refrigerador e moderador (Duderstadt e Hamilton, 1976; Hannum et al., 2006).

Os reatores de água pressurizada (PWR) dominam hoje o mercado mundial e foram desenvolvidos pela Westinghouse (Angra I) e adotados pela Siemens na Alemanha (Angra II) e pela Areva (antiga Framatone) francesa, que hoje é proprietária da Siemens-Nuclear (Rosa, 2007, p. 52).

Aproximadamente $60 \%$ dos reatores no mundo são desse tipo e a escolha por esse reator deve-se aos rigorosos princípios de segurança aplicados na operação e manutenção das usinas (ELETRONUCLEAR, 2002).

A Fig. 3 demonstra um reator de potência do tipo PWR, juntos, esse tipo de reator e o BWR respondem por $88 \%$ da capacidade mundial de geração presente e $85 \%$ da capacidade nominal a ser construída ou em projeto (Bodansky, 2004).

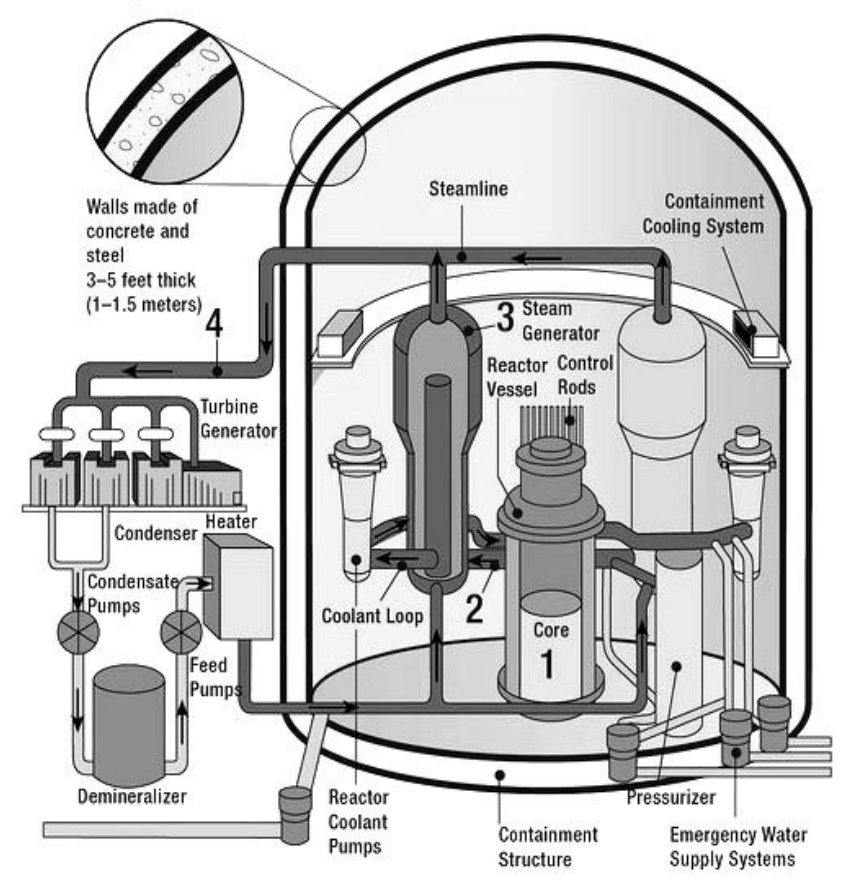

FIGURA 3. Reator do tipo PWR (Pressurized Water Reactor) Fonte: U.S. NRC, 2015. 
O desenvolvimento dos reatores denominados reatores de nova geração também causarão grande efeito sobre à tecnologia dos reatores já existentes no mundo. Essa nova geração de reatores visa aumentar a segurança, aumentar a eficácia na operação das usinas, a redução de custos, além de produzir menos rejeitos, o que se daria pelo uso de combustíveis mais eficientes, de longa queima, e que ainda é um grande problema a ser solucionado pela tecnologia nuclear. Isso permitiria reduzir o número de paradas para troca de combustíveis, aumentando assim a rentabilidade da geração nuclear (Amantéa; Mesquita, 2014).

Os reatores de nova geração, em desenvolvimento tecnológico têm previsão de funcionamento apenas para 2020 (Milanez, Almeida, Carmo, 2006; Goldberg e Rosner, 2011).

\subsection{Repositório de rejeitos radioativos}

Um repositório é uma instalação para o armazenamento seguro de rejeitos radioativos e deve ser construído e operado respeitando a legislação e a vida humana. Para deposição, esses rejeitos devem estar em conformidade com critérios estabelecidos no projeto e que estipulam a forma de acondicionamento, 0 tipo de rejeito e outras características (Ferreira e Soares, 2012, p. 316).

Os rejeitos radioativos são quaisquer materiais resultantes de atividades humanas que contenha radionuclídeos (materiais radioativos) em quantidades superiores aos limites estabelecidos por normas da CNEN e de acordo com parâmetros internacionais de segurança recomendados pela Agência Internacional de Energia Atômica - AIEA (IRD, 2015), e para o qual a reutilização é imprópria ou não prevista.

Esses rejeitos são gerados durante a operação dos reatores nucleares de potência, pelas instalações do ciclo do combustível e por usuários de radioisótopos em aplicações na medicina, na indústria, agricultura e em pesquisas (Almeida, 2010).

No Brasil, os rejeitos radioativos ficam armazenados em depósitos iniciais e intermediários também sob guarda da CNEN, mas, com a operação de Angra III, ainda em construção e outras instalações, há a necessidade de um repositório nacional para armazenar os rejeitos de todas as atividades do país, como fontes antigas utilizadas na medicina e na indústria não nuclear, rejeitos da indústria do petróleo; na mineração e metalurgia; na extração de areias 
monazíticas, e dos materiais denominados como NORMs ou TENORMs (materiais radioativos de origem natural e materiais radioativos de origem natural e concentrados tecnologicamente).

A norma CNEN-NN 8.01 - Gerência de Rejeitos Radioativos de Baixo e Médio Níveis de Radiação, é quem estabelece os critérios gerais e requisitos básicos de segurança e proteção radiológica, bem como de rejeitos radioativos de meia-vida muito curta, já a norma CNEN-NN 8.02 - Licenciamento de Depósitos de Rejeitos Radioativos de Baixo e Médio Níveis de Radiação, estabelece os critérios gerais e requisitos básicos de segurança e proteção em atendimento à Lei 10.308/2001 (CNEN, 2014).

O Instituto de Engenharia Nuclear (IEN) no Rio de Janeiro é a única unidade da Comissão Nacional de Energia Nuclear (CNEN) autorizada a possuir um depósito intermediário para rejeitos de baixa e média atividade.

Os rejeitos de alta atividade provenientes das usinas Angra I e Angra II são armazenados na própria Central Nuclear de Angra dos Reis- RJ, prestando serviços de tratamento e armazenamento de rejeitos radioativos que possuam essas características (IEN, 2015).

Nos projetos de repositórios deve-se levar em consideração o período pós-construção, prevendo uma contínua abertura ao diálogo e a aceitação da participação na comunidade local em decisões da gestão de repositórios que estejam relacionadas com a própria comunidade, bem como manter uma preocupação constante com o relacionamento com a comunidade (Almeida, 2010).

Segundo Deutch e Moniz (2006), um dos grandes obstáculos da energia nuclear é o gerenciamento dos seus resíduos. Nenhum país ainda desenvolveu um sistema de descarte permanente do combustível consumido e de outros materiais radioativos.

\subsection{Serviços de medicina nuclear}

De acordo com Machado, M. et al. (2011), nas instalações de saúde onde ocorre o uso de fontes radioativas, um conjunto de medidas deve estar contida em um plano de radioproteção, um documento que deve ser submetido à CNEN contendo informações quanto à proteção radiológica mediante a solicitação para funcionamento de um Serviço de Medicina Nuclear - SMN. Nesse documento, devem constar as exigências nas normas vigentes, como o objetivo da instalação, 
projeto das blindagens e da área física, aquisição, uso e armazenamento de fontes radioativas, gerenciamento de rejeitos radioativos, estimativas de doses, sinalizações, identificação e classificação de áreas e qualificação dos profissionais envolvidos.

No Brasil, a norma CNEN-NN-3.05 estabelece os requisitos de segurança e proteção radiológica para serviços de medicina nuclear. Esses requisitos determinam como devem ser planejadas essas dependências, desde a sala de espera de pacientes até os quartos para internação desses pacientes inclusive com sanitário privativo, quando forem aplicadas doses terapêuticas de radiofármacos.

Muitos locais onde não se realizam necessariamente serviços diretamente da área de medicina nuclear, mas utilizam-se de radiações ionizantes como os consultórios dentários, não possuem cadastro no órgão responsável para realizar tais atividades.

\subsubsection{Medicina nuclear}

É a especialidade da medicina que emprega radionuclídeos para o diagnóstico e o tratamento de determinadas patologias, para realizar avaliações diagnósticas das condições anatômicas e fisiológicas, tratamentos terapêuticos e pesquisas médicas (Oliveira, R. et al, 2008; Santini, 2011). Qualquer procedimento de radiodiagnóstico ou radioterapêutico na medicina nuclear ainda não seria possível se não fossem utilizados radiofármacos.

\subsubsection{Radiofarmácia}

Os centros de radiofarmácia são os setores onde são produzidos os radiofármacos, substâncias marcadas para observar alterações fisiológicas ou distribuição anormal de um determinado composto administrado em um ser vivo, ou ainda como compostos de ação terapêutica na clínica médica.

São compostos que não possuem ação farmacológica, e apresentam em sua composição radionuclídeos que são utilizados na medicina nuclear. Para diagnóstico, os radiofármacos utilizados apresentam na sua constituição radionuclídeos emissores de radiação you emissores de pósitrons $\left(\beta^{+}\right)$, cujo decaimento gera radiação eletromagnética penetrante, que consegue atravessar os tecidos, enquanto que para a terapia, a composição deve ser de um 
radionuclídeo emissor de partículas ionizantes ( $\alpha, \beta$ - ou elétrons Auger), pois a sua ação se baseia na destruição seletiva de tecidos.

Os radiofármacos podem ainda ser classificados em radiofármacos de perfusão (ou 1a geração) que transportados no sangue atingem um órgão alvo e radiofármacos específicos (ou $2^{\text {a }}$ geração) que contêm uma molécula biologicamente ativa, que se liga a receptores celulares (Oliveira, R. et al, 2006).

Os radiofármacos começaram a ser utilizados em 1905 após a descoberta do raio-X por Roentgen. O primeiro uso de radionuclídeos em humanos ocorreu em 1927, quando foi medida a circulação humana após injeção de uma solução salina exposta ao radônio e estudos sobre a função da tireóide com o uso do lodo $\left({ }^{131}\right.$ I) marcaram o início do uso dos radionuclídeos na medicina (Oliveira, R.S. et al., 2008).

A produção desse radionuclídeo ocorreu por volta de 1959, no Brasil com uma parceria entre o CNPq e a USP e criação do IEA, atual IPEN. Esses substratos podem ser administrados por via oral, inalados ou, o mais comum, por via intravenosa, sendo de grande aplicação na medicina nuclear. 


\section{DIREITO AMBIENTAL NO BRASIL}

A partir da Lei norte-americana de 1968, National Environmental Policy Act (NEPA) promulgada pelo Congresso dos Estados Unidos (EUA), primeira a estabelecer a obrigatoriedade da Avaliação de Impacto Ambiental (AIA), verificouse a necessidade de apresentação de relatórios diante dos órgãos ambientais competentes mediante a identificação dos prováveis impactos ao meio ambiente e efeitos negativos em relação ao projeto.

Os Estados Unidos parece ter sido o primeiro país a responder de forma abrangente a uma insistente, embora incipiente demanda do público por ação para proteger a qualidade do meio ambiente (Caldwell, 1998, p.4 apud Jay et al., 2007).

Como os problemas ambientais não eram exclusivos dos Estados Unidos, vários outros países como Portugal adotaram esse modelo norteamericano, como instrumentos de política ambiental. No Brasil, a primeira experiência surgiu antes de uma lei que tornasse obrigatório esse processo.

Devido os financiamentos de alguns projetos no Brasil através do Banco Mundial e a Companhia Estadual de Energia Elétrica do Estado de São Paulo (CESP) foram feitas exigências para que fossem levados em consideração os impactos causados pelos empreendimentos construídos. Sendo assim, essas instituições provavelmente seriam os precursores da elaboração dos instrumentos legais de avaliação de impactos ambientais no país como a Avaliação de Impactos Ambientais (AIA) e de outros instrumentos complementares: o Estudo de Impacto Ambiental (EIA) e o Relatório de Impacto Ambiental (RIMA) (Barbieri, 1995; Basso e Verdum, 2006).

Segundo Rocha (2008) em torno de 1985 apenas alguns países como a Colômbia, a Venezuela, o México e o Brasil haviam adotado a AIA como instrumento de política ambiental.

No Brasil, a disseminação da AIA ocorreu a partir da Conferência das Nações Unidas realizada em Estocolmo em 1972, que teve seus princípios reafirmados pela Conferência das Nações Unidas sobre o Meio Ambiente e o 
Desenvolvimento (CNUMAD), realizada em junho de 1992 no Rio de Janeiro, também conhecida como ECO-92.

Junto a essa conferência, ocorria o Fórum Global 92, que contava com a participação de várias Organizações não Governamentais (ONG's) e outros setores da sociedade civil onde houve a aprovação da Carta da Terra, documento que apresenta como princípio o respeito ao meio ambiente, à integridade ecológica, à justiça socioeconômica e à paz com o intuito de melhorar a qualidade de vida das pessoas, assim como o Tratado de Educação Ambiental para Sociedades Sustentáveis e Responsabilidade Global, documento de apoio à Educação Ambiental (Rodrigues e Colesanti, 2008).

Dessa conferência, foram provenientes cinco documentos como: a Declaração do Rio, a Agenda 21, a Convenção sobre a Mudança do Clima, Convenção da Biodiversidade e os Princípios para a Administração Sustentável das Florestas, sendo a Agenda 21 um dos documentos mais importantes por promover novos padrões de desenvolvimento sustentável e dar ênfase à Educação Ambiental contínua. Surgiu a partir daí a Agenda 21 brasileira, Agenda 21 estaduais e Agenda 21 municipais (Rocha, 2008; Rodrigues e Colesanti, 2008).

Durante esse período foi criada a Lei Federal $n^{\circ} 6.938$ e seu respectivo Decreto em 1983 n 99.351 que, estabeleceriam as diretrizes da Política Nacional do Meio Ambiente (PNMA) instrumento legal substituído posteriormente pela Lei Federal $n^{\circ} 7.804$ de 1989 e seu respectivo Decreto $n^{\circ} 99.274$ de 1990.

Como instrumento da PNMA foram também elaboradas diretrizes para a AIA e de suas ferramentas complementares como o EIA e o RIMA representando um avanço importante no tratamento das questões ambientais e fornecendo subsídios para o planejamento e a gestão ambiental, objetivando a preservação, melhoria e recuperação da qualidade ambiental, assim como a prevenção relativa aos danos ambientais (Barbieri, 2004; Basso e Verdum, 2006).

Observa-se na Tabela 2 o denominado Sistema Nacional do Meio Ambiente (SISNAMA) criado através da Lei 6.938/81 e constituído por órgãos e entidades da União e as funções pertinentes a cada um deles. Embora a Lei tenha sido aprovada em 1981, sua implementação só foi efetivada ao final dessa década. 
TABELA 2. Órgãos componentes do SISNAMA (Sistema Nacional do Meio Ambiente).

\begin{tabular}{|c|c|}
\hline ÓRGÃO & FUNÇĀO \\
\hline $\begin{array}{l}\text { Superior: } \\
\text { Conselho de Governo }\end{array}$ & $\begin{array}{l}\text { Auxiliar na elaboração de políticas } \\
\text { públicas. }\end{array}$ \\
\hline $\begin{array}{l}\text { Orgão consultivo e deliberativo: } \\
\text { Conselho Nacional do Meio Ambiente (CONAMA) }\end{array}$ & $\begin{array}{l}\text { Analisa e delibera diretrizes e normas } \\
\text { sobre política ambiental. }\end{array}$ \\
\hline $\begin{array}{l}\text { Orgão central: } \\
\text { Ministério do Meio Ambiente, dos Recursos Hídricos da } \\
\text { Amazônia (MMA) }\end{array}$ & $\begin{array}{l}\text { Planejamento, coordenação, } \\
\text { supervisão e controle da PNMA. }\end{array}$ \\
\hline $\begin{array}{l}\text { Orgão executor: } \\
\text { Instituto Brasileiro do Meio Ambiente e Recursos Naturais } \\
\text { (IBAMA). }\end{array}$ & $\begin{array}{l}\text { Executa e fiscaliza a política } \\
\text { ambiental em âmbito Federal. }\end{array}$ \\
\hline Instituto Chico Mendes (ICM-BIO) & $\begin{array}{l}\text { Administrar as unidades de } \\
\text { conservação federais, estaduais e } \\
\text { municipais. }\end{array}$ \\
\hline $\begin{array}{l}\text { Órgãos setoriais: } \\
\text { Órqãos ou entidades da Administracão Federal }\end{array}$ & $\begin{array}{l}\text { Atividades diretas ou indiretamente } \\
\text { relacionadas ao Meio Ambiente. }\end{array}$ \\
\hline $\begin{array}{l}\text { Órgãos seccionais: } \\
\text { Órgãos ou entidades dos Estados e Distrito Federal }\end{array}$ & $\begin{array}{l}\text { Responsáveis pelas políticas } \\
\text { ambientais em âmbito Estadual. }\end{array}$ \\
\hline $\begin{array}{l}\text { Orgãos locais: } \\
\text { Órgãos ou entidades municipais }\end{array}$ & $\begin{array}{l}\text { Responsáveis pelas políticas } \\
\text { ambientais em âmbito municipal. }\end{array}$ \\
\hline
\end{tabular}

Fonte: Adaptada de Barbieri, 2004.

\subsection{Legislação ambiental}

Segundo Antunes (2008) o Direito Ambiental pode ser definido como: "Um direito fundamental que cumpre a função de integrar os direitos à saudável qualidade de vida, ao desenvolvimento econômico e à proteção dos recursos naturais (...)"

Conforme se verifica no art. 3º, I, da Lei 6.938/81 (a Lei da Política Nacional do Meio Ambiente):

"Art. $3^{\circ}$ Para os fins previstos nesta Lei, entende-se por:

I - Meio ambiente, o conjunto de condições, leis, influências e interações de ordem física, química e biológica, que permite, abriga e rege a vida em todas as suas formas".

Há tempos o homem vem assumindo um papel poluidor do meio ambiente principalmente após a explosão demográfica, as atividades industriais, as guerras pela invasão de territórios, utilização de armas nucleares, e a era moderna com a utilização dos computadores, contudo, o planeta poderá estar fadado à expiração dos recursos naturais caso não sejam tomadas providências rígidas.

O direito ao meio ambiente ecologicamente equilibrado no Brasil, a exemplo de outros países, é apresentado e estruturado como direito fundamental por ser essencial à qualidade de vida; e tem como meta, entre outras, a defesa dos 
recursos ambientais de uso comum, ou seja, o patrimônio da humanidade, necessários para uma vida digna (Teixeira, 2006, p. 67).

Em pouco tempo, a evolução legislativa foi significativa, os próprios legisladores começaram a se interessar pelas questões ambientais por entenderem que o meio ambiente não é um bem exclusivamente individual.

Dessa forma, para Fiorillo (2013), a criação da Lei 6.938/81 representou uma grande investida na tutela dos direitos individuais, e, em 1985 a Lei 7.343 veio disponibilizar um aparato processual sempre que houvesse danos ao meio ambiente, ao consumidor, aos bens e direitos de artístico, histórico e outros: a ação civil pública. 


\section{LICENCIAMENTO AMBIENTAL DE INSTALAÇÕES NUCLEARES}

\subsection{Aspectos gerais}

O licenciamento ambiental foi regulamentado pela União em 1981, por meio da Lei 6.938, de 31 de agosto de 1981 que dispõe sobre a Política Nacional do Meio Ambiente (PNMA).

De acordo com o IBAMA (2013), "O licenciamento ambiental é uma obrigação legal prévia à instalação de qualquer empreendimento ou atividade potencialmente poluidora ou degradadora do meio ambiente", podendo ser considerado um conjunto de etapas que compõe o procedimento administrativo, no qual se objetiva a concessão de licença ambiental (Fiorillo, 2013, p.236).

Ele vem sendo efetivado perante um dos órgãos que compõem o SISNAMA, na maior parte dos casos o órgão seccional (estadual) e, nos casos de empreendimentos com significativo impacto ambiental de âmbito nacional ou regional, é o IBAMA que atua como órgão licenciador (Araújo, S., 2002).

Compete também ao IBAMA o licenciamento de empreendimentos e atividades com significativo impacto ambiental de âmbito nacional ou regional, destinados a pesquisar, lavrar, produzir, beneficiar, transportar, armazenar e dispor material radioativo, em qualquer estágio, ou que utilizem energia nuclear em qualquer de suas formas e aplicações, mediante parecer da CNEN (CONAMA, 2013).

As principais diretrizes para a execução do licenciamento ambiental estão expressas na Lei 6.938/81 e nas Resoluções CONAMA no 001/86 e no 237/97. Além dessas, recentemente foi publicado a Lei Complementar ㄲo 140/2011, que discorre sobre a competência estadual e federal para o licenciamento, tendo como fundamento a localização do empreendimento (IBAMA, 2015).

É fato que as mudanças ambientais podem ocorrer tanto através dos fenômenos naturais como por ação humana, assim, podendo gerar efeitos positivos ou negativos. Quando provenientes da ação humana os aspectos positivos conferem sustentabilidade à instalação proposta e os negativos, impacto naquele ambiente. 
Entende-se por impacto ambiental, "às alterações no meio ambiente físico, biótico e social decorrentes de atividades humanas em andamento ou propostas" (Barbieri, 2004).

A Resolução CONAMA 001/86 veio para estabelecer os critérios e diretrizes para a realização da AIA e a elaboração do EIA e seu respectivo relatório, o RIMA, para atividades causadoras de impacto ambiental, permitindo inclusive um possível acesso pelo público através da realização de audiências públicas (Rocha, 2008).

Para Tilleman (1995, p. 346), "a AIA e seus instrumentos complementares como o EIA/RIMA devem ser um processo completo e que forneça informações e alternativas razoáveis para evitar ou minimizar esses impactos ambientais".

De acordo com 0 art. 2ํ da Resolução 001/86 (CONAMA) dependerá de elaboração de EIA/RIMA a ser submetido à aprovação do órgão estadual competente e do IBAMA em caráter supletivo, o licenciamento de atividades modificadoras do meio ambiente ou causadoras de impacto ambiental como:

I. Estradas de rodagem;

II. Ferrovias;

III. Portos e terminais de minérios, petróleo e produtos químicos;

IV. Aeroportos;

V. Oleodutos, gasodutos, minerodutos, tronos coletores e emissários de esgotos sanitários;

VI. Linhas de transmissão de energia elétrica, acima de 230kW;

VII. Obras hidráulicas para exploração de recursos hídricos como: barragens para fins hidrelétricos (acima de 10MW), de saneamento ou irrigação, canais para navegação, drenagem e irrigação, retificação de cursos d'água, abertura de barras, transposição de bacias, diques;

VIII. Extração de combustível fóssil;

IX. Extração de minério;

X. Aterros sanitários, processamento e destino final de resíduos tóxicos ou perigosos;

XI. Usinas de geração de energia, qualquer que seja a fonte de energia primária, acima de $10 \mathrm{Mw}$; 
XII. Complexos e unidades industriais e agroindustriais;

XIII. Distritos industriais e zonas estritamente industriais;

XIV. Exploração econômica de madeira e lenha;

XV. Projeto urbanístico acima de 100ha ou relevante interesse ambiental pelo IBAMA;

XVI. Qualquer atividade que utilize carvão ou derivados;

XVII. Projetos agropecuários inclusive nas áreas ambientais;

XVIII. Nos casos de empreendimentos potencialmente lesivos ao patrimônio espeleológico nacional;

Além das atividades citadas acima, ainda dependem do Estudo de Impacto Ambiental (EIA) para licenciamento:

- Instalações nucleares;

- Portos marítimos.

- Infraestrutura aeroportuária;

- Parcelamento e remembramento do solo ou qualquer atividade que altere as características naturais das zonas costeiras;

- Obras de saneamento que possam causar alterações ambientais significativas.

Diferente de alguns países que adotaram tais medidas para avaliar o impacto causado ao meio ambiente por grandes empreendimentos, até hoje, a Argentina ainda não conta com uma legislação de âmbito nacional para a AIA (Verocai, 2004, apud Rocha et al., 2005, p. 155), sendo assim, legislar fica por conta de cada província.

No Paraguai, em 31 de dezembro de 1993 foi instituída a Ley de Evaluación de Impacto Ambiental no 294/93, regulamentada em 31 de julho de 1996 pelo Decreto $n^{\circ} 14.281 / 96$, que define responsabilidades, determina o conteúdo mínimo do EIA/RIMA, lista as atividades que devem submeter-se ao processo de Estudo de Impacto Ambiental e submete o EIA à audiência pública, quando o órgão licenciador, Direção de Ordenamento Ambiental (DOA), julgar necessário. Esse mesmo órgão emite apenas uma licença para todas as etapas dos empreendimentos. Para os projetos onde não é necessária a AIA, a Defesa Nacional e o DOA ficam responsáveis pela lista de exclusão dessas obras. Ainda, é colocada à disposição do empreendedor, uma lista de empresas de consultoria ambiental (Rocha et al., 2005). 
Segundo o autor, no Uruguai, de acordo com a Lei n 16.466/94 (Ley de Evaluación de Impacto Ambiental), que instituiu a Avaliação de Impactos Ambientais, regulamentada pelo Decreto $n^{\circ} 435 / 94$, promulgado em 21 de setembro de 1994, os impactos ambientais são conceituados como negativos ou nocivos e são definidas também responsabilidades e determinado o conteúdo necessário para a elaboração do EIA e a exigência do RIMA (Informe Ambiental Resumen). Esses documentos poderão ser submetidos à audiência pública se os projetos implicarem em repercussões graves de ordem cultural, social ou ambiental. Fica responsável pela emissão da autorização prévia, a Direção Nacional do Meio Ambiente, já no início da atividade. Os projetos recebem classificação em categorias como A, B e C de acordo com a necessidade ou não de EIA.

Na Colômbia, o Congresso aprovou a Lei 99 de 1993 que estabelece que para atividades causadoras de impacto ambiental como as de geração de energia, a autorização para instalação das mesmas ocorre através da concessão de licenças ambientais. É de competência do Ministério do Ambiente do país, o reconhecimento do licenciamento ambiental de acordo com as disposições da Lei e pelo Decreto 1220/2005. Para os projetos sob competência do Ministério do Ambiente, é necessária a solicitação do Diagnóstico de Alternativas Ambientais (DAA), e, após o recebimento desse documento, em 10 dias inicia-se a avaliação dos estudos e em 30 dias elege-se a melhor alternativa para a elaboração do EIA que deve estar fixado de acordo com o Termo de Referência, tendo, o órgão competente tem 16 semanas para essa avaliação. O EIA é elaborado com a participação da comunidade interessada em uma chamada consulta prévia e posteriormente há a realização de audiências públicas, quando convocada por 100 cidadãos ou 3 entidades sem fins lucrativos (Ministerio de Ambiente, Vivienda y Desarollo Territorial, 2008).

A França também adota, em sua legislação, a obrigatoriedade do Estudo de Impacto Ambiental, um conjunto complexo e muito burocratizado. Após um longo debate parlamentar, a Assembleia Nacional Francesa aprovou uma lei, aos 10 de julho de 1976, sendo que a regulamentação da norma, ocorreu somente com a expedição do decreto de 12 de outubro de 1977, cuja vigência teve início em 1ํ de janeiro de 1978 (Yamaguchi e Souza, 2011, p. 61).

Para as análises ambientais do projeto a ser implementado são utilizados três modelos como: Mininotícia de Impacto, que trata-se de um relatório 
contendo as implicações ambientais do projeto proposto, que deve ser realizado pelo empreendedor, depois de ouvir os órgãos de controle ambiental; Notícia de Impacto, um relatório sucinto indicativo do nível em que um projeto respeita o meio ambiente; o Estudo de Impacto, onde a legislação francesa adota o princípio de que toda obra deve ser previamente submetida a um estudo de impacto estabelecendo uma lista positiva - necessidade do EIA - e uma lista negativa desnecessidade do EIA, isto é, classifica algumas obras que não precisarão passar pelo prévio estudo de impacto, entre elas, obras de reparação e manutenção; obras de instalação de serviços: gás, esgoto, água e telecomunicações. O regime francês de estudos de impacto determina ainda que a responsabilidade pela realização é do próprio proponente do projeto, mas o sistema é falho, pois o autor do projeto dificilmente apontará que ele não deve ser levado avante por razões de ordem ecológica. Há uma previsão legal para que, em certas situações, o estudo de impacto seja realizado por instituições científicas e universidades (Antunes, 2008, p. 272).

Nos Estados Unidos, a agência reguladora das atividades nucleares, a NRC (Nuclear Regulatory Comission), analisa e examina os pedidos apresentados pelos potenciais empreendedores e, estando de acordo com os requisitos exigidos pelo órgão para o licenciamento, são emitidos certificados, autorizações e licenças de local, instalação/construção e operação (U.S NRC, 2016).

Em países como Brasil, Estados Unidos e Portugal as semelhanças entre os procedimentos adotados consistem na adoção dos mesmos princípios: o princípio da prevenção; do planejamento racional e da oportunidade de participação pública. A avaliação de impacto ambiental nesses países apresenta-se como um procedimento prévio à instauração do projeto cujo objetivo é garantir que os fatores ambientais e sociais sejam levados em consideração quando da tomada de decisão sobre a aprovação de determinado empreendimento. Os três sistemas estudados se identificam por respeitarem trâmites muito parecidos, já que adotam etapas como: a apresentação da proposta; análise preliminar; determinação do escopo; elaboração do estudo; análise técnica do estudo; consulta pública e a tomada de decisão (Pimenta, 2012).

Nos Estados Unidos, existe um prazo de 60 dias para o requerimento das audiências públicas para a instalação de reatores após a publicação no chamado Federal Register e, caso não haja qualquer manifestação sobre o 
empreendimento, o órgão regulador, a NRC (Nuclear Regulatory Comission), dá o parecer final. A United States Nuclear Regulatory Comissions (NRC) considera muito importante a participação do público nas atividades da agência, oferecendo oportunidades para que os cidadãos possam ser ouvidos. Informações sobre a regulamentação do empreendimento e as reuniões públicas são anunciadas no website do órgão para permitir a participação do público interessado. É permitida ainda a participação do público em todas as etapas do licenciamento até as audiências públicas para a concessão das licenças (U.S. NRC, 2016).

\subsection{Aspectos brasileiros}

Para a realização e/ou estabelecimento de qualquer atividade ou empreendimento nuclear há a necessidade de licenciamento nuclear e ambiental, processos esses que devem ser submetidos respectivamente tanto à CNEN como ao IBAMA.

Cabe à essas instituições avaliar os impactos gerados por essas atividades tanto para a comunidade, as equipes de trabalhadores envolvidos e ao meio ambiente. Ainda, são elas responsáveis pela emissão de licenças e autorizações, estabelecendo aos empreendedores, procedimentos que priorizem os aspectos positivos de tais instalações e minimizem os impactos causados por elas (INB, 2013).

A norma CNEN 6.02, que trata do licenciamento de instalações radioativas, revogada e substituída pela Resolução CNEN no 112, de 24 de agosto de 2011 publicada no D.O.U. em 01.09.2011, dispõe sobre o licenciamento de instalações radiativas que utilizem fontes seladas, fontes não-seladas, equipamentos geradores de radiação ionizante e instalações radioativas para a produção de radioisótopos.

Há de se ressaltar que a atividade nuclear no País está prevista na legislação que segue:

\section{- Constituição da República Federativa do Brasil de 1988:}

"Art. 21. Compete à União:

XXIII - explorar os serviços e instalações nucleares de qualquer natureza e exercer monopólio estatal sobre a pesquisa, a lavra, o enriquecimento e reprocessamento, a industrialização e o comércio de minérios nucleares e seus derivados, atendidos os seguintes princípios e condições: 
a) toda atividade nuclear em território nacional somente será admitida para fins pacíficos e mediante aprovação do Congresso Nacional;

b) sob regime de permissão, são autorizadas a comercialização e a utilização de radioisótopos para a pesquisa e usos médicos, agrícolas e industriais; (Redação dada pela Emenda Constitucional no 49, de 2006)

c) sob regime de permissão, são autorizadas a produção, comercialização e utilização de radioisótopos de meia-vida igual ou inferior a duas horas; (Redação dada pela Emenda Constitucional no 49, de 2006)

d) a responsabilidade civil por danos nucleares independe da existência de culpa; (Incluída pela Emenda Constitucional no 49, de 2006).

"Art. 22. Compete privativamente à União legislar sobre:

XXVI atividades nucleares de qualquer natureza;

Parágrafo único. Lei complementar poderá autorizar os Estados a legislar sobre questões específicas das matérias relacionadas neste artigo"

"Art.177. Constituem monopólio da União:

V - a pesquisa, a lavra, o enriquecimento, o reprocessamento, a industrialização e o comércio de minérios e minerais nucleares e seus derivados, com exceção dos radioisótopos cuja produção, comercialização e utilização poderão ser autorizadas sob regime de permissão, conforme as alíneas b e $\underline{c}$ do inciso XXIII do caput do art. 21 desta Constituição Federal.

"Art. 225. Todos têm direito ao meio ambiente ecologicamente equilibrado, bem de uso comum do povo e essencial à sadia qualidade de vida, impondo-se ao Poder Público e à coletividade o dever de defendê-lo e preservá-lo para as presentes e futuras gerações.

IV exigir, na forma da lei, para instalação de obra ou atividade potencialmente causadora de significativa degradação do meio ambiente, estudo prévio de impacto ambiental, a que se dará publicidade; (Regulamento)

$\S 2^{\circ}$ Aquele que explorar recursos minerais fica obrigado a recuperar o meio ambiente degradado, de acordo com solução técnica exigida pelo órgão público competente, na forma da lei.

$\S 6$ As usinas que operam com reator nuclear deverão ter sua localização definida em lei federal, sem o que não poderão ser instaladas. "

De acordo com a norma CNEN-NE-1.04 de julho de 1991, o licenciamento das instalações nucleares envolve as seguintes etapas (INB, 2013): - Aprovação do Local: onde a CNEN aprova a localização, distribuição da população, vias de acesso, características físicas do ambiente, influência no meio ambiente e possíveis acidentes, programa preliminar de monitoração ambiental, 
- Licença de Construção (total ou parcial): para essa licença são necessários dados sobre o cronograma preliminar da obra, os prazos para término da construção pretendida e documentos como o Relatório Preliminar de Análise de Segurança (RPAS) e o Plano Preliminar de Proteção Física.

- Autorização para Utilização de Materiais Nucleares (AUMAN): deve ser solicitada à CNEN, e será concedida caso sejam satisfeitos requisitos como o requerente ser tecnicamente qualificado para utilizar o material nuclear que procedimentos de controle de material nuclear, propostos pelo requerente no Plano de Controle sigam a Norma CNEN-NE-2.02 e que sejam atendidas condições adicionais que a CNEN exija, a fim de promover melhor controle do material nuclear.

- Autorização para Operação Inicial (AOI) e Autorização para Operação Permanente (AOP): deve ser requerida em duas etapas, sendo a primeira relativa à operação inicial e a segunda à entrada em operação em caráter permanente.

Os documentos necessários para a obtenção da Autorização para Operação Inicial (AOI) são o Relatório Final de Análise de Segurança (RFAS) e o Plano Final de Proteção Física. Os dados necessários para a obtenção da (AOP) referem-se ao prazo de operação desejado, dados complementares relativos ao requerente, que não tenham sido incluídos no RFAS, relatório circunstanciado, descrevendo o desenvolvimento das atividades na fase de AOI, relatório detalhado, apresentando os resultados dos testes realizados durante a operação inicial, programa de Garantia da Qualidade e a demonstração de que a construção da instalação está completamente terminada.

Em fevereiro de 2016, foi divulgada em Diário Oficial através de Instrução Normativa (IN) a competência do órgão ambiental, o IBAMA no que se refere ao licenciamento e regularização ambiental de instalações radioativas, ficando sob a responsabilidade do SISNAMA a regularização somente das atividades não radioativas da mesma instalação. Essa mesma IN determina que caberá à CNEN emitir um parecer técnico prévio à expedição da licença ambiental.

De acordo com o porte e tipo de atividade do empreendimento, haverá três tipos de procedimento para o licenciamento, classificados como 1, 2 e 3. Nos procedimentos de número 1 serão enquadrados os cíclotrons com exigência de LP, LI e LO, nos de número 2, as instalações que geram rejeitos rotineiramente, sendo necessárias a LI e LO ou somente LO à critério do IBAMA, e, nos de número 3, as 
instalações que não tem como rotina gerar rejeitos, sendo necessária apenas a LO (IBAMA, 2016).

\subsection{Etapas do licenciamento}

O licenciamento ambiental é dividido em três etapas: licença prévia (LP), licença de instalação (LI) e licença de operação (LO), onde, para a aquisição de licença prévia, há necessidade da discussão e análise do EIA/RIMA.

Para a implantação de atividades causadoras de impactos ambientais, são exigidas as licenças ambientais, instrumentos prévios de controle ambiental para qualquer atividade modificadora do meio ambiente (Cunha e Guerra, 2012).

Para a obtenção das licenças ambientais, são estabelecidas as condições, restrições e medidas de controle ambiental para que o empreendedor, implante, amplie ou opere o empreendimento. Essas licenças não são definitivas e apresentam prazos de validade mínimo e máximo como consta na Tabela 3 , diferentes para cada tipo, (LP), (LI) e (LO).

TABELA 3. Prazos de validade das licenças ambientais

\begin{tabular}{c|c|l}
\hline Tipo de licença & Prazo & \multicolumn{1}{c}{ Prazo mínimo } \\
\hline Licença Prévia (LP) & 5 anos & $\begin{array}{l}\text { Estabelecido pelo cronograma dos planos } \\
\text { ambientais. Pode ser prorrogado contanto que } \\
\text { não ultrapasse o prazo máximo. }\end{array}$ \\
\hline $\begin{array}{c}\text { Licença de Instalação (LI) } \\
\text { Licença de Operação } \\
\text { (LO) }\end{array}$ & 6 anos & $\begin{array}{l}\text { Mínimo de 4 anos ou segundo os planos } \\
\text { ambientais. Prazos específicos para } \\
\text { empreendimentos sujeitos a encerramentos em } \\
\text { prazos menores. }\end{array}$ \\
\hline
\end{tabular}

Fonte: Adaptada de Barbieri, 2004.

Independentemente do tipo de licença requerida, no art. 14 do CONAMA 237/97, o prazo regimental para que o órgão ambiental se manifeste acerca do requerimento é de até seis meses, ressalvada a hipótese de requerimentos instruídos por EIA/RIMA, quando o prazo é de até 12 meses. Para os requerimentos de revalidação da LO, o prazo regimental é de até 90 dias. Não é computado nesses prazos o tempo gasto pelo empreendedor para apresentar informações complementares (MMA, 2015).

Quando um órgão ambiental aprova ou nega o licenciamento de um empreendimento, ele expõe também as vantagens e desvantagens dessa decisão, 
assim, o Estado quando assume uma determinada postura diante de um problema ou conflito ambiental, define como se distribuirão os custos e os benefícios decorrentes desse processo e permitindo a participação de amplos setores da sociedade nos processos decisórios sobre a destinação dos recursos ambientais. (Quintas, 2009 apud Serrão, 2011).

O órgão ambiental também pode modificar ou cancelar a licença atual caso haja violação ou inadequação de condicionantes, omissão de informações relevantes e situações que tragam graves riscos ambientais e de saúde.

É importante que haja um acompanhamento após a concessão das licenças, e, caso seja identificado o não cumprimento do que foi estabelecido, essas licenças podem ser canceladas (Araújo, 2002; Barbieri, 204)).

\subsubsection{EIA/RIMA}

O processo de regulamentação para o licenciamento ambiental teve início por meio da Resolução CONAMA no 001/86, que estabeleceu diretrizes gerais para elaboração do EIA/RIMA definindo também, critérios para sua aplicação. $O$ EIA/RIMA constitui-se num importante meio de implantação de uma política preventiva, sendo, portanto, um documento de subsídio ao processo de licenciamento ambiental, além de ser um dos instrumentos necessários para que haja a concessão das licenças e caracterizar se o empreendimento é causador de impacto ambiental, sendo essa conceituação de responsabilidade do órgão licenciador (Caderno Licenciamento Ambiental, 2009; Machado, P., 2009).

\subsubsection{Licença prévia (LP)}

É a primeira etapa do licenciamento enunciada no art. $8^{\circ}$, I, da Resolução CONAMA no 237/97, concedida na fase preliminar do planejamento da atividade/empreendimento, aprovando a sua localização, viabilidade ambiental e estabelecendo requisitos básicos e suas condicionantes a serem atendidas nas próximas fases de implementação observando-se os planos municipais, estaduais ou federais de uso do solo (Fiorillo, 2013, p. 240; Trennepohl, 2010, p. 53). Na Fig. 4 encontram-se os requisitos básicos para a solicitação da Licença Prévia (LP), a primeira fase do licenciamento ambiental. 


\section{Primeira fase: Licença Prévia}

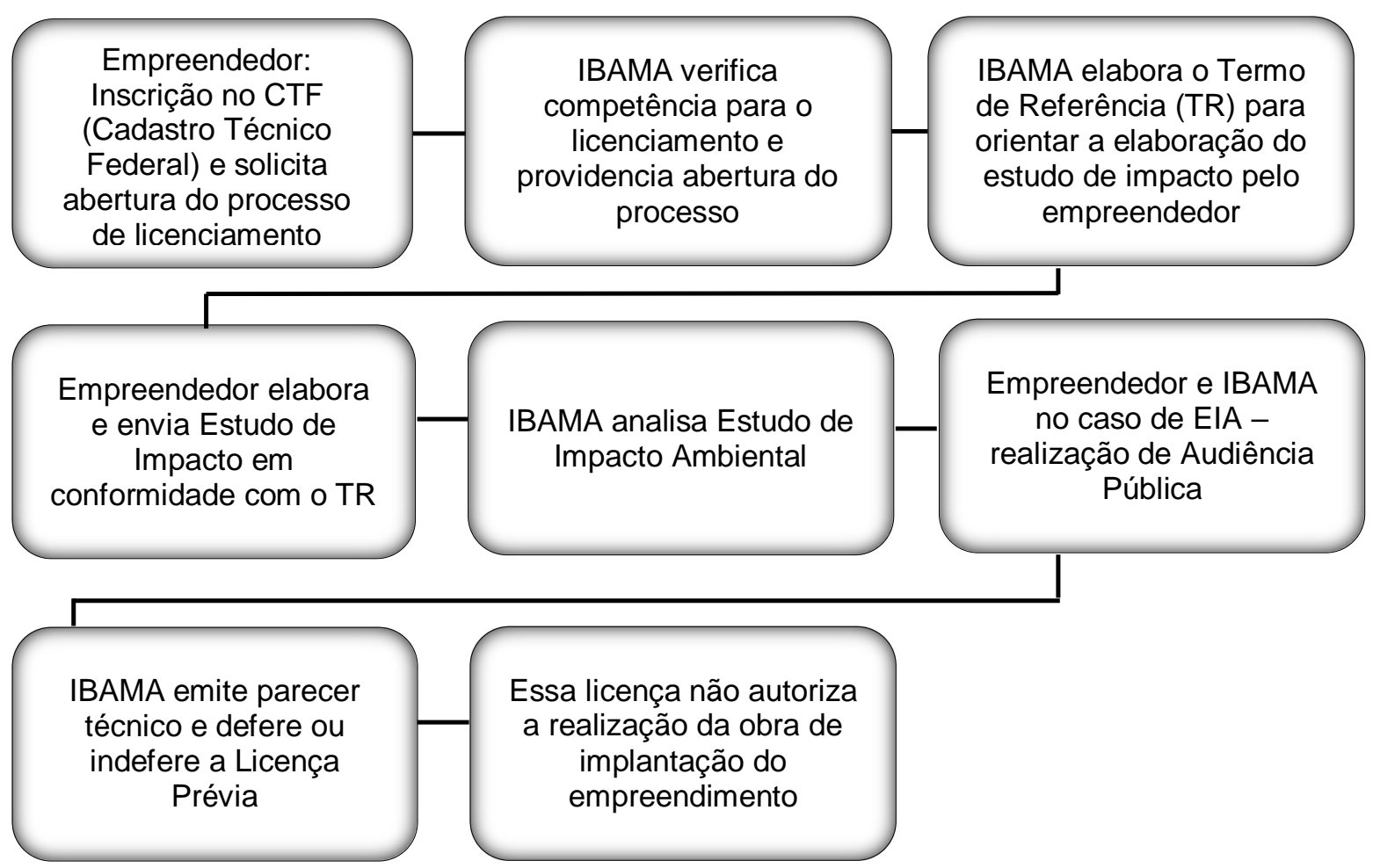

FIGURA 4. Diagrama esquemático para obtenção da Licença Prévia.

Fonte: Adaptado do IBAMA, [201?].

\subsubsection{Licença de instalação (LI)}

É a licença que autoriza a instalação do empreendimento e pode ser prorrogada, mas sem ultrapassar os limites de validade da licença (Trennepohl, 2010).

É o tipo de licença concedida após análise e aprovação do projeto executivo e de outros estudos conforme preceitua o art. 8으, II, da Resolução CONAMA 297/97, onde a LI, precedida pela LP, autoriza a instalação do empreendimento ou atividade de acordo com as especificações constantes dos planos, programas e projetos aprovados, incluindo as medidas de controle ambiental e demais condicionantes..." (Cunha e Guerra, 2012, p.99; Fiorillo, 2013).

A execução do projeto deve ser realizada de acordo com o modelo apresentado ao órgão competente, sendo que, qualquer alteração realizada na planta ou nos sistemas instalados deve ser informada ao órgão licenciador para nova avaliação (MMA, 2004). A Fig. 5 demonstra o passo a passo para a obtenção da LI, a segunda fase do licenciamento ambiental. 


\section{Segunda fase: Licença de Instalação}

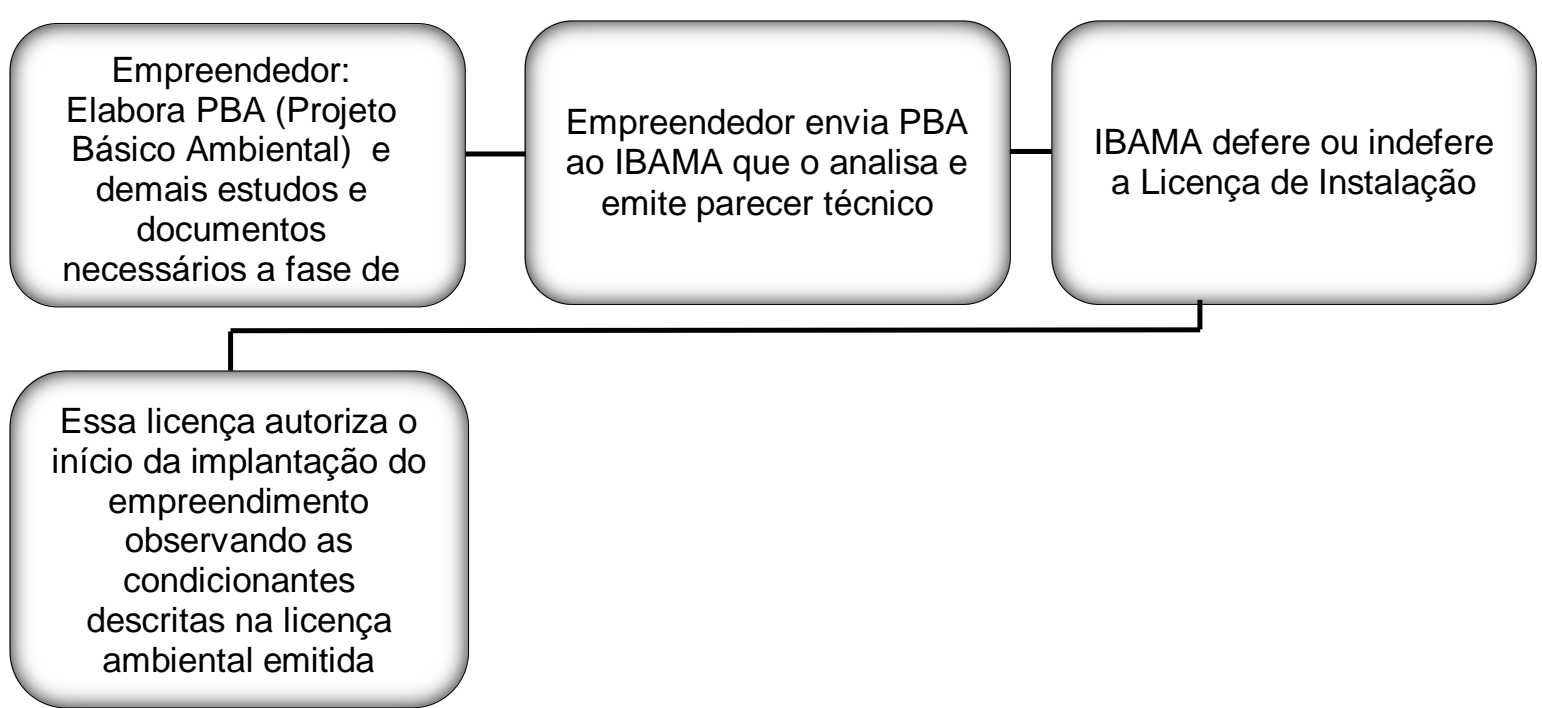

FIGURA 5. Diagrama esquemático para obtenção de Licença de Instalação.

Fonte: Adaptado do IBAMA, [201?].

\subsubsection{Licença de operação (LO)}

É a licença que vai autorizar a operação do empreendimento e deve ser solicitada quando o empreendimento estiver edificado (MMA, 2004). Nessa etapa é a licença que autoriza, após algumas verificações do que consta nas licenças anteriores, o início das atividades e funcionamento de equipamentos de controle de poluição (Barbieri, 2004; Fiorillo, 2013). A Fig. 6 demonstra as etapas necessárias para a obtenção da LO, terceira fase do licenciamento ambiental.

Com a intenção de adequar às licenças a algumas necessidades específicas, alguns órgãos incluem outros tipos de licença. O IBAMA criou a Licença de Pré-Operação para a fase de teste de equipamentos de controle de poluição, licença concedida de acordo com as características do projeto.

Cunha e Guerra (2012) listam ainda outros documentos técnicos que podem ser exigidos para a obtenção de licença:

- Plano de Controle Ambiental (PCA): trata da exigência do PCA para a obtenção de Licença de Instalação (LI) de atividades de extração mineral das classes de I a $\mathrm{IX}$, que conta com projetos que visam minimizar os impactos ambientais; 
- Relatório de Controle Ambiental (RCA): exige a apresentação do RCA para a obtenção de Licença Prévia (LI) no caso de dispensa de EIA/RIMA para a atividade de extração mineral da classe II.

- Plano de Recuperação de Áreas Degradadas (PRAD): fixa as diretrizes para a elaboração de Planos de Recuperação de Áreas Degradadas pelas atividades de mineração.

\section{Terceira fase: Licença de Operação}

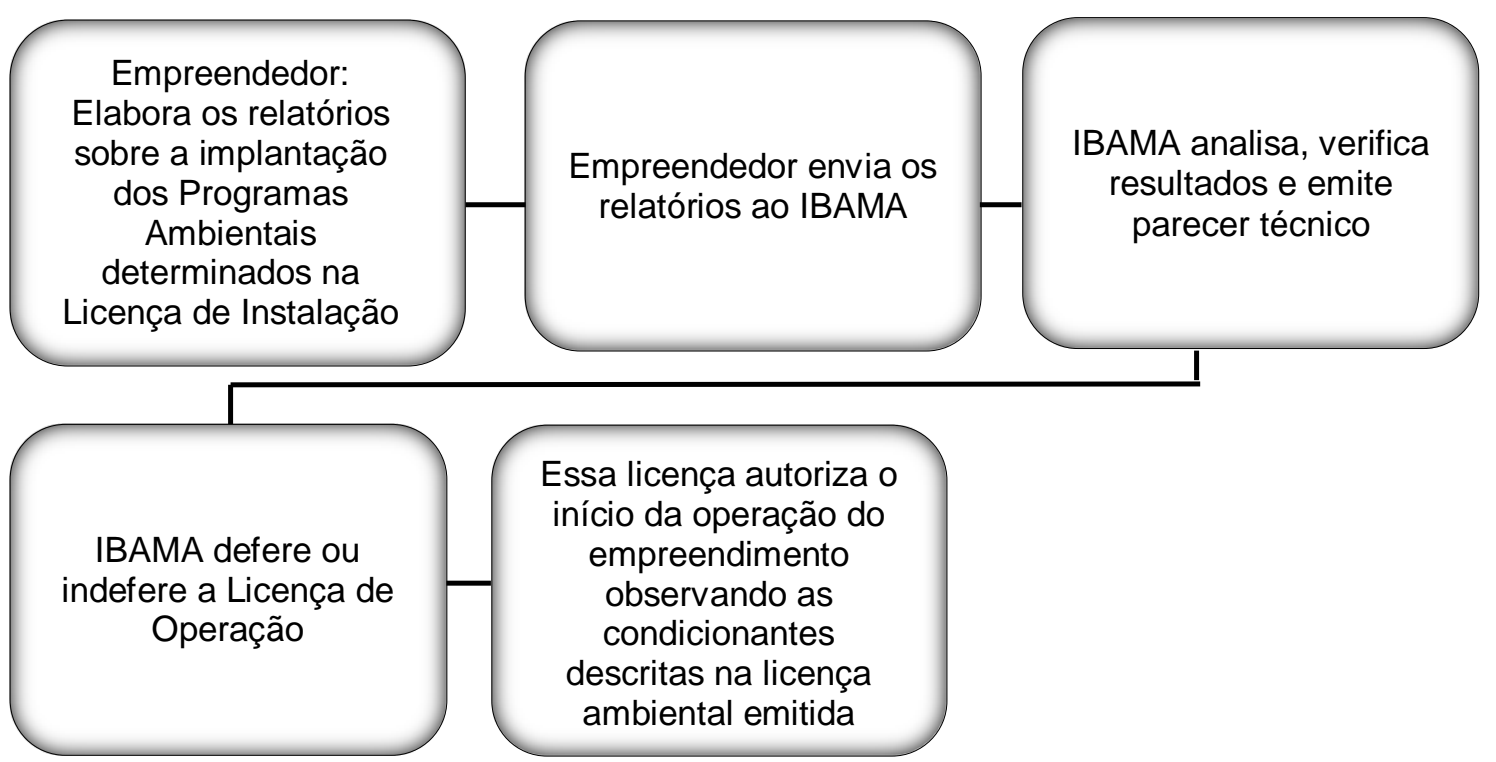

FIGURA 6. Diagrama esquemático para a obtenção da Licença de Operação (LO)

Fonte: Adaptado do IBAMA, [201?].

Para as atividades que não se enquadrem em extração mineral, a legislação não exige esses documentos, no entanto, alguns órgãos ambientais fazem uso dos mesmos principalmente em locais onde já existem efeitos negativos de empreendimentos já instalados.

Já o Relatório de Avaliação de Desempenho Ambiental do Sistema de Controle e demais Medidas Mitigadoras (RADA) atua no processo de revalidação da LO que tem por objetivo submeter o empreendimento a uma avaliação periódica. A revalidação da LO é também a oportunidade para que o empreendedor explicite os compromissos ambientais voluntários assumidos, bem como algum passivo ambiental não conhecido ou não declarado por ocasião da LP ou da LI ou da primeira LO (SEMAD, 2015). 


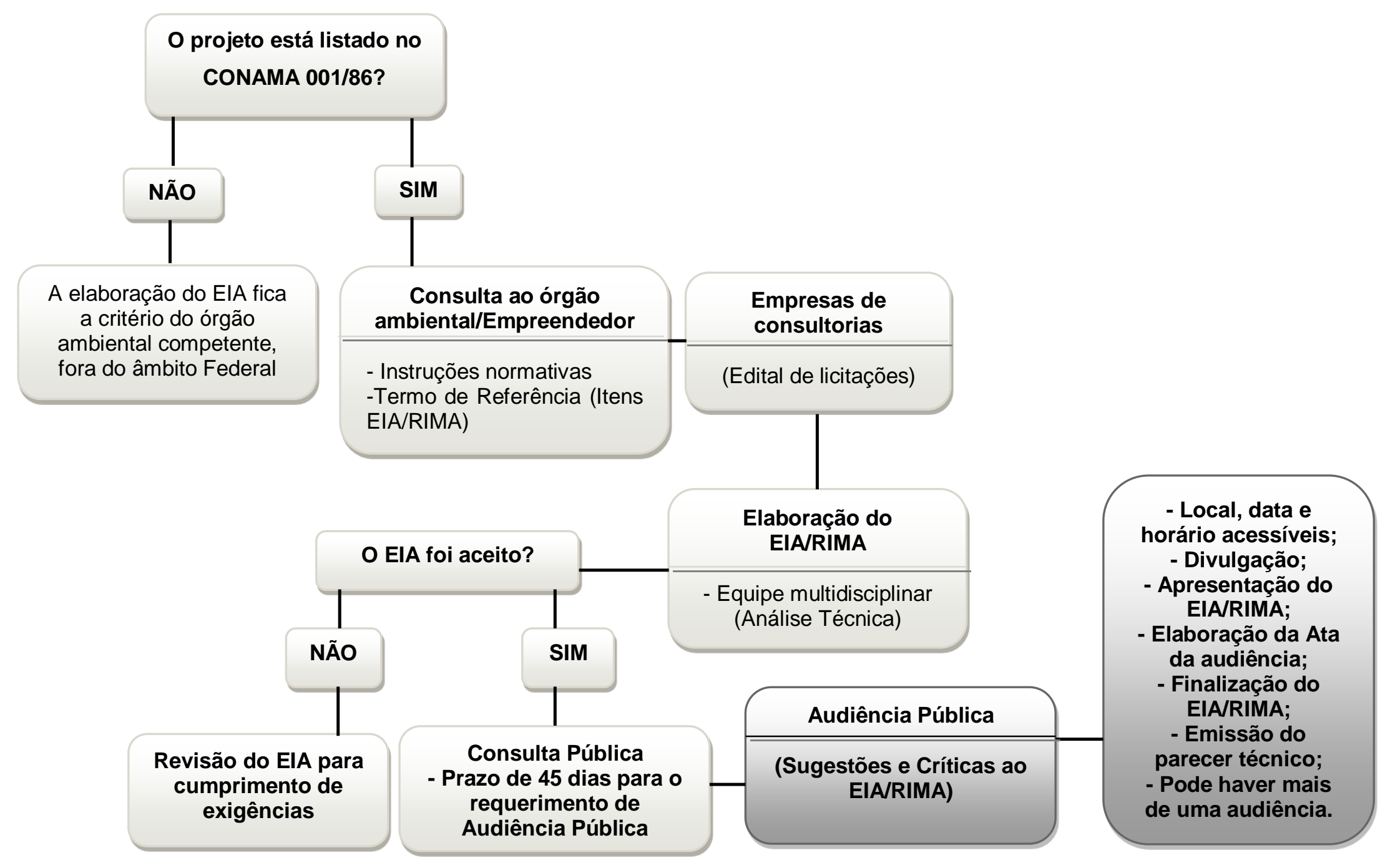

Figura 7. Etapas do processo de Licenciamento Ambiental no Brasil (CONAMA 001/86) Fonte: Adaptada de CONAMA 001/86 e 009/87 


\subsection{Programas de compensação ambiental}

A Lei 9.985 de 18 de julho de 2000, que instituiu o Sistema Nacional de Unidades de Conservação (SNUC), previu em seu artigo 36, uma compensação ambiental devida por ocasião do licenciamento ambiental de empreendimentos que causem significativo impacto ambiental (Domingues e Carneiro, 2010).

A compensação ambiental é um instrumento que se refere à aplicação de um percentual da receita na indústria na manutenção de reservas indígenas e de unidades de conservação, nada estipulado aos chamados problemas urbanos do município, cabendo ao empreendedor a obrigação de apoiar a implantação e manutenção de unidade de conservação (Silva, G., 2009, p. 777; MMA, 2016).

De acordo com Serrão (2011), as medidas de controle e monitoramento interagem com Projetos de Educação Ambiental assegurando um controle sobre o empreendimento, tendo resultados divulgados por meio do Projeto de Comunicação Social, aumentando a confiança em torno do empreendimento, do órgão licenciador e melhorando as ações educativas. Outros projetos ambientais podem exigidos como medidas mitigadoras/compensatórias por parte da população local ou quando o órgão ambiental entender ser necessário.

De acordo com a nova redação do artigo 31, introduzida pelo Decreto 6.848/09, é de competência do IBAMA estabelecer o grau de impacto de acordo com o EIA/RIMA a fim de fixar o valor da compensação ambiental, no entanto, não é qualquer empreendimento licenciado pela autarquia Federal que pode ser obrigado a pagar a compensação, apenas aqueles onde o impacto ultrapasse 0 território estadual (Domingos e Carneiro, 2010).

Ainda no artigo 31-A do Decreto 4.340/02, com redação dada pelo Decreto 6.848/09, o valor da compensação ambiental derivada do licenciamento ambiental federal deve ser calculado pelo produto do Grau de Impacto (Gl) com o valor de referência $(\mathrm{VR})$, ou seja, $\mathbf{C A}=\mathbf{V R} \times \mathbf{~ G l}$, onde: CA refere-se ao valor da compensação ambiental, Gl ao grau de Impacto nos ecossistemas, podendo atingir valores de 0 a $0,5 \%$ do empreendimento. O VR refere-se ao somatório dos investimentos necessários para implantação do empreendimento, sem incluir os investimentos referentes aos planos, projetos e programas exigidos no procedimento de licenciamento ambiental para mitigação de impactos causados pelo empreendimento, bem como os encargos e custos incidentes sobre o 
financiamento do empreendimento, inclusive os relativos às garantias, e os custos com apólices e prêmios de seguros pessoais e reais.

No EIA/RIMA também deverá constar as informações necessárias ao cálculo do Gl e as informações necessárias ao cálculo do VR e, deverão ser apresentadas pelo empreendedor ao órgão licenciador antes da emissão da licença de instalação. Da decisão do cálculo da compensação ambiental caberá recurso no prazo de dez dias, conforme regulamentação a ser definida pelo órgão licenciador (MMA, 2015). 


\section{AUDIÊNCIA PÚBLICA}

Vivemos atualmente, o antagonismo entre a racionalidade capitalista, que visa o progresso e a ambientalista, trabalhando em defesa da preservação do meio ambiente.

O desenvolvimento econômico, científico e tecnológico trouxe muitas vantagens à sociedade, mas notadamente, a degradação ambiental representa grandes riscos à todas as formas de vida do planeta sendo o seu valor imensurável (Weschenfelder, 2010).

O fato de o bem ambiental ser considerado de interesse público e do Estado visando a qualidade ambiental para as presentes e futuras gerações, vem despertando aos poucos o interesse da sociedade na participação dos processos de licenciamento ambiental, um dos instrumentos para o desenvolvimento sustentável, que acaba gerando conflitos entre grupos de interesse, tendo que levar em consideração todos os trâmites legais para a solução de problemas como a omissão pública e ainda a definição do órgão competente a analisá-lo a fim de buscar a democracia tão preconizada pela legislação (Castro, 2006; Machado, A., 2010).

Foi através da Constituição Federal de 1988, democrática e cidadã, que se firmou o princípio da participação popular, um dos princípios-alicerce da proteção ambiental, como o princípio concretizador do Estado Democrático de Direito (Oliveira, L. 2007, p.13), entretanto, não basta garantir legalmente aos cidadãos o direito de participar por meio de informações, estabelecendo-se conselhos, audiências públicas, fóruns, procedimentos e práticas, quando a apatia da população à participação é generalizada e que ocorre devido ao descrédito com os políticos e instituições (Furriela, 2001 apud Barros, 2004).

Na Resolução CONAMA 001/86, em seu art. 1ํ, as audiências públicas têm por finalidade expor aos interessados o conteúdo do produto em análise, o EIA e do seu referido RIMA, dirimindo dúvidas e recolhendo dos presentes as críticas e sugestões a respeito, e, para que se firme esse direito, a Resolução CONAMA 
009/87 dispõe sobre as regras de realização de audiências públicas no processo de licenciamento ambiental para as atividades causadoras de impacto ambiental (CONAMA, 2015).

De acordo com Figueiredo (2007); Machado, P. (2009), a Constituição de 1988 também permitiu que a democracia se realizasse por intermédio dos representantes do povo, do interesse público e da coletividade por meio das audiências públicas, direito difuso e não individual fundamentada na Lei 8.666/93 art.39, que disciplina as Licitações e Contratos.

Essa lei abriu não só as portas à participação popular, como determinou que toda instituição pública tem por obrigação zelar pelo correto uso dos recursos devendo assegurar a escolha da melhor proposta em termos de qualidade e preço. Essa mesma lei, em seu art. 12, indica ainda que o exame do impacto ambiental é indispensável e não pode ser desprezado.

Outras leis tornaram obrigatória a realização das audiências públicas, como as Leis de Processo Administrativo (Federal e Paulista de no 9.784/99 art. 32 e 34 e 10.177/98, art. 29 e 31, a Lei de Responsabilidade Fiscal (Lei Complementar no 101/2000, art. 9ํ) e o Estatuto da Cidade (Lei o 10.257/2001, art. 2o, XIII), além das Telecomunicações e Energia Elétrica (Lei 9.427/96).

As audiências públicas fazem parte do mais antigo regime amplamente utilizado na tomada de decisões, sendo consideradas eventos formais, convocados e conduzidos por um ente governamental, cuja dinâmica segue regras previamente estabelecidas pelo órgão licenciador, no caso o IBAMA e tem como finalidade realizar um debate público - aberto a todos os cidadãos - sobre um projeto e seu impacto (Sanchez, 2010, p. 414; Zhong e Mol, 2008).

No Ocidente foram aplicadas em processos judiciais, gradualmente expandido para o legislativo, administrativo e ambiental, como parte do processo da Avaliação de Impacto Ambiental (Zhong e Mol, 2008).

Segundo Soares (2002) e Baptista (2006), a audiência pública é um instrumento de conscientização comunitária e trata-se de uma instância no processo de tomada da decisão administrativa ou legislativa, através da qual a autoridade competente abre espaço para que todos os cidadãos que possam sofrer as consequências dessas decisões se manifestem antes do desfecho final do processo evitando equívocos para a aprovação e concretização do projeto. 
A audiência pública não é um ato político, assembleia deliberativa, reunião de condôminos, para a qual se devam observar protocolos de anterioridade e convocação previstos em estatutos. Esse processo não delibera nada, caso contrário, a ordem pública estaria invertida, retirando a responsabilidade indelegável do órgão competente de autorizar ou não o empreendimento (Pedro, 2014).

A participação pública nessas audiências, de extrema importância no processo de AIA e seus componentes, o EIA e o RIMA, garantem credibilidade ao projeto, permitindo o compartilhamento de fatos únicos, particularidades da região primordiais ao projeto proposto, assim, como podem conduzir a decisões que evitem a realização de outras audiências públicas caso o proponente satisfaça 0 público e os impactos ambientais sejam insignificantes ou mitigáveis (Tilleman, 1995).

Essas reuniões, além de levar e divulgar para o público informações sobre o RIMA, buscam a participação de pessoas, autoridades e organizações ambientais ou não que tenham interesses ou responsabilidades, ou seja, sobre a implantação de atividades potencialmente poluidoras e causadoras de degradação ambiental.

A população pode opinar sobre os possíveis impactos das instalações, mas, na maioria das vezes faltam esclarecimentos sobre seus direitos e sobre o próprio processo de licenciamento ambiental, onde a participação efetiva ocorre em um momento em que os acordos fechados entre os órgãos interessados já foi efetivamente consumado (Zhouri, 2004).

Em todo o processo de licenciamento ambiental deve-se levar em conta a manifestação pública que se materializa na obrigação jurídica de que o órgão licenciador avalie o futuro empreendimento e realize um reexame, em profundidade, de todos os aspectos criticados ou questionados, fundamentalmente, no ponto mais alto de toda discussão, as audiências públicas, que só tem fundamento quando ocorre intervenção da sociedade, caso contrário, seu objetivo se perde (Barros, 2004).

Diante disso, como promover a conscientização dos grupos sociais excluídos das decisões tomadas e que provocarão alterações em seu cotidiano já que, de acordo com a legislação as decisões cabem somente ao órgão licenciador? Que ferramentas podem ser utilizadas para garantir uma participação mais efetiva 
dos grupos atingidos por tais instalações? Quando o processo de licenciamento poderá criar estratégias para que esses grupos sejam mais atuantes na gestão ambiental em seus territórios? Quando o licenciamento será um objeto de desenvolvimento socioambiental e não só de desenvolvimento econômico? (Serrão, 2011).

$\mathrm{Na}$ Colômbia, as informações fornecidas sobre o empreendimento são limitadas a simples reuniões, o que não garante participação real e efetiva, demonstrando uma grande fragilidade das autoridades ambientais na criação de estratégias de interação com as comunidades (Rodríguez, 2011).

No México, durante o MIA (Manifesto de Impacto Ambiental) revisados pela Secretaria de Estado do Meio Ambiente e Habitação, a participação do público ocorre a critério da própria secretaria, a partir de uma solicitação escrita, onde, é mantida na internet também uma lista de todos os detalhes do projeto em análise. Cabe ao promotor divulgar em jornal o MIA e solicitar pelo menos uma reunião pública para a discussão do projeto, no Peru, não há participação do público (Verocai, 2004).

Em países como a China, existe uma gama de formas de participação pública, pesquisas de opinião, conselhos de consumidores, conferências e as próprias audiências públicas, que sofrem grandes críticas por não serem métodos eficazes na tomada de decisões pelo público e também por não fornecer aos participantes, um impacto real sobre as decisões governamentais (Zhong e Mol, 2008). No país, o grande desafio é que os funcionários do governo, pesquisadores e até professores universitários são contra o conceito de participação do público nessas decisões, levando em consideração o grau de conhecimento dos participantes. Muito políticos e acadêmicos notam a participação do público como mera formalidade, sem muito efeito para o processo.

$\mathrm{Na}$ China, a grande preocupação está mais em informar do que necessariamente consultar o público. As autoridades chinesas sentem-se desconfortáveis ainda com a participação do público nas audiências públicas ambientais, o receio está em realmente promover mudanças em decisões já tomadas (THE WOODROW WILSON CENTER, 2006, p. 99).

É nítida a apatia e falta de interesse da população devido os entraves políticos extremamente burocráticos e em relação a leitura sobre os aspectos relacionados ao ambiente em que vivem. 
Nos Estados Unidos, Portugal e no Brasil, a semelhança se refere à consulta pública, onde a oportunidade de participação popular é uma característica essencial ao instrumento de gestão ambiental brasileiro, norte-americano e português, no entanto, apesar de firmar bases na ideia de bem comum e no direito de acesso à informação, acaba por ser realizada de forma tardia em todos os três sistemas analisados (Pimenta, 2012). A peculiaridade do modelo norte-americano é que a licença ambiental é concedida pelo órgão regulador nuclear NRC (Nuclear Regulatory Comission), e não pela agência reguladora ambiental EPA (Environmental Protection Agency) nuclear. A Fig. 8 demonstra as etapas do processo de licenciamento nos Estados Unidos até a realização das audiências públicas e decisão final pelo órgão regulador.

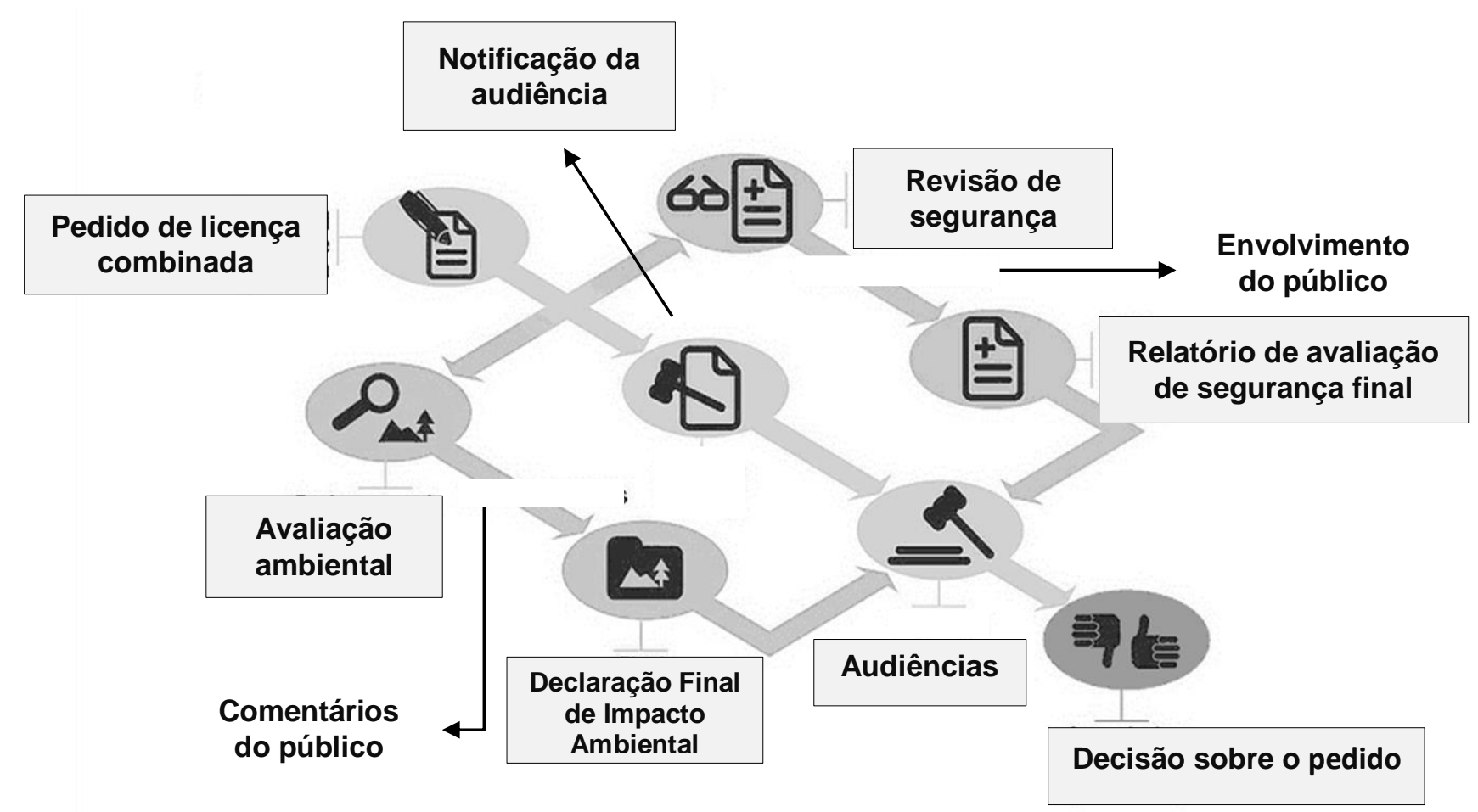

Figura. 8 - Etapas do licenciamento nos Estados Unidos até as audiências públicas e decisão final do órgão regulador.

Fonte: Adaptado de U.S. NRC, 2016.

Para a manifestação de um ponto de vista não se exige cidadania, portanto, o público que opina sobre o EIA nas audiências pode ser constituído de nacionais ou estrangeiros (Machado, P., 2009). 
Barros (2004, p. 170) afirma que para que a audiência pública transcorra sem atropelos e torne o processo administrativo ambiental mais célere para 0 empreendedor, é necessário que haja um trabalho precedente junto às comunidades localizadas na área de abrangência das atividades. A comunicação entre o empreendedor e a população antes e durante a audiência pública traz benefícios para ele próprio, para a população e o órgão de controle ambiental objetivando inclusive seu sucesso empresarial.

Para Fernandes (2014), a comunicação entre as partes envolvidas não faz parte somente de um subprograma ambiental, pois ela atende às questões políticas de debate, discussão, troca de conhecimento e promove uma melhora na qualidade do empreendimento e do meio ambiente. Reconhecidamente, o procedimento de comunicação e publicidade no Brasil sobre as audiências públicas é ainda muito frágil e limitado, os anúncios transmitidos pela mídia encontram-se muitas vezes dispostos em locais não apropriados e totalmente fora do contexto da maioria das pessoas, fugindo, portanto, do verdadeiro objetivo que é atingir um grande número de participantes dessas reuniões.

As audiências públicas atualmente estão menos prestigiadas, com menor participação do público onde, predomina a variável "econômica" e os participantes estão mais preocupados com o dinamismo econômico e com a geração de empregos que o empreendimento pode trazer à região ou ao município onde será instalada (Basso e Verdum, 2006).

Segundo Beierle (1998) uma série de estudos identificou que a maioria dos participantes nas audiências públicas representam interesses organizados com desafios econômicos significativos nos resultados dessas reuniões, e, ainda, este último aspecto sugere que o valor educativo das audiências é limitado, sendo necessário instruir o governo em relação as forças políticas sobre o assunto

De acordo com Ferreira e Soares (2012), através de uma pesquisa realizada em 27 países da União Europeia, pôde-se concluir que a maioria dos cidadãos quer ser diretamente consultada e gostaria de participar da tomada de decisões durante o processo de licenciamento ambiental de instalações nucleares.

No sistema norte-americano, para os responsáveis pela elaboração do EIA, a confiança depositada pela população sobre essa perícia é até inadequada no que se refere aos problemas sem solução sobre as instalações nucleares e que 
incluem: a evacuação de emergência, a desativação das instalações e o destino final dos resíduos.

A participação pública é necessária para a gestão eficaz sobre os riscos e há uma dupla caminhada: o órgão público presta informações ao público e o público passa informações à Administração Pública (Machado, P., 2009).

Segundo o Instituto Estadual do Ambiente - INEA (2013), a Legislação Federal dá autonomia aos estados para que estabeleçam suas próprias normas para a realização das audiências públicas de licenciamento ambiental, eventos esses, públicos e abertos à comunidade e todas as autoridades governamentais, promotores públicos federais e estaduais e outros representantes da sociedade civil (ONG's ambientais ou de outras áreas) que são convidados a comparecer.

O $\S 2^{\circ}$, do artigo 192, repetindo a regra contida na Constituição da República, estabeleceu que, quando da aprovação do EIA/RIMA, a este se dará publicidade, acrescentando que será "garantida a realização da audiência pública" (Fink, 1995, p. 62).

Conforme Barbieri (1995) os procedimentos para tornar público o RIMA são possibilitar o acesso às cópias do mesmo aos centros de documentação, divulgando a existência desse material, estabelecer um período para comentários de órgãos interessados e a realização de audiências públicas (obrigatórias no caso de instalações nucleares) para discussão desse relatório.

Nos projetos que exigem o EIA é necessária pelo menos uma audiência pública, que é o caso das instalações nucleares, onde o IBAMA tem, por norma, exigir a realização da audiência pública independentemente de solicitação (Sanchez, 2010; INB, 2013).

Para os órgãos licenciadores, as audiências públicas permitem um diagnóstico dos impactos que os mesmos podem causar ao meio ambiente, no entanto, ela não é obrigatória em todos os processos de licenciamento ambiental.

Para o empreendedor, a audiência pública torna-se uma maneira de legitimar sua atividade perante a sociedade organizada (Silva, G. 2009; Trennepohl, 2010).

O desafio do empreendedor no que diz respeito às relações com os interessados consiste em desenvolver estratégias e firmar acordos satisfatórios com a comunidade sem abrir mão de seus valores éticos, morais e filosóficos, assim como identificar as necessidades, as expectativas e as percepções das partes 
interessadas e buscar soluções que possam compensar interesses prejudicados (Almeida, 2010).

As formalidades das audiências não impedem a participação do público em qualquer fase do processo de licenciamento, no entanto, a existência de problemas de acesso e informações são inevitáveis. De qualquer forma, uma audiência pública pode subsidiar a impugnação de um empreendimento.

Rocha (2008) afirma que as audiências públicas, geralmente realizadas antes da fase de licença prévia, podem ser convocadas quando os níveis de conflito forem motivados pelo elevado comprometimento do meio ambiente relacionado à atividade desenvolvida, sendo assim, as audiências não apresentam caráter decisório, mas permitem a expressão pública antes do fechamento do projeto e sua implantação, assim como aplicam-se quando há necessidade de correções de instalações já implantadas.

Para um mesmo empreendimento podem ser realizadas mais de uma audiência enquanto o RIMA não estiver de acordo com as exigências dos órgãos competentes, assim, como a licença do órgão competente não terá validade caso não seja realizada a audiência pública (Sanchez, 2010).

Uma das principais intenções da audiência pública é conhecer a reação da sociedade ao empreendimento proposto, dando ao cidadão oportunidade de influir na gestão ambiental, pela resposta à consulta formulada. E é exatamente por ser esta a sua motivação, que a audiência não tem caráter vinculatório para a decisão a ser adotada pelo órgão licenciador (Barros, 2004, p.165).

Para um mesmo empreendimento podem ser realizadas mais de uma audiência enquanto o RIMA não estiver de acordo com as exigências dos órgãos competentes, assim, como a licença do órgão competente não terá validade caso não seja realizada a audiência pública (Sanchez, 2010).

Quanto à dinâmica das audiências públicas, o tempo e período de duração podem apresentar algumas variações dependendo dos locais onde são realizadas, mas geralmente, apresentam características em comum.

De acordo com Sanchez (2010), "Digno de nota é o mecanismo existente na legislação federal canadense, e, também em algumas províncias, de auxílio financeiro para que os interessados participem do processo de consulta pública, contratando assessorias que facilitem 0 entendimento dos documentos apresentados". 
No Brasil, as audiências acabam por perder seu real objetivo, para Silva, G. (2009) as audiências são utilizadas para discussão das compensações e ressarcimentos da empresa à comunidade.

A Fig. 9 demonstra bem essas características, onde existe toda uma formalidade exigida pelo órgão ambiental e um fluxo descontínuo do público, os atores, que deveria ser o maior interessado nesse processo.

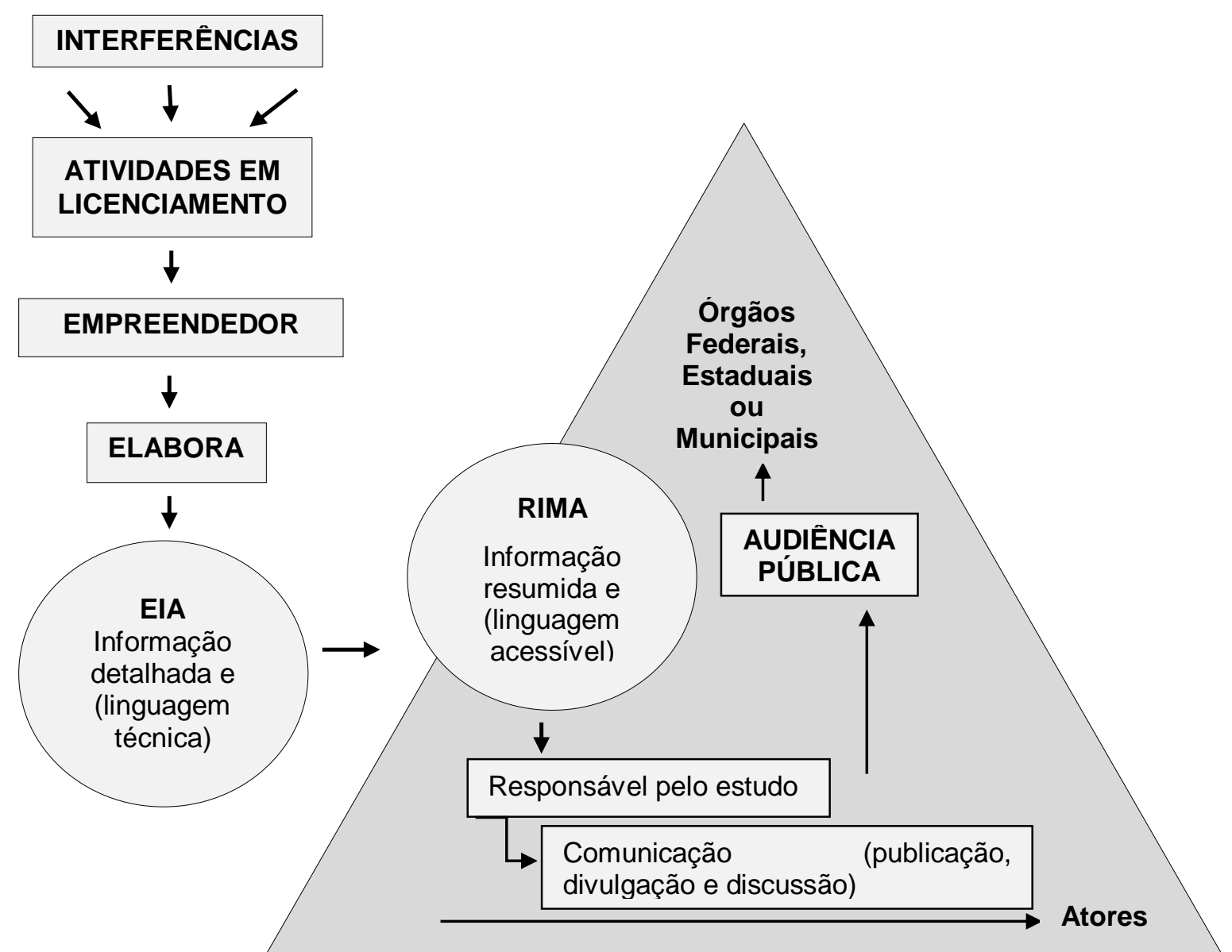

FIGURA 9. Conjunto de operações envolvidas na transmissão de informações para a audiência, desde sua origem até sua utilização.

Fonte: Barros, 2004.

Na Hungria, em Ófalu, no ano de 1978 durante a seleção de um local para a instalação de um repositório nuclear, grande parte da população mostrouse contrária à essa decisão paralisando o processo e considerando a compensação ambiental equivocada e uma forma de suborno (Ferreira e Soares, 2012; Vari, 1996).

Cabe ao órgão licenciador, o IBAMA, avaliar as considerações feitas pelos participantes, mas não é obrigação do mesmo levá-las em consideração no 
que se refere às concessões das licenças ambientais, não havendo seguramente um retorno sobre o que foi resolvido e discutido durante a audiência realizada.

Na Tabela 5 baseada no CONAMA 09/87, verifica-se uma lista das tarefas e responsabilidades para a preparação das audiências públicas referente a empreendimentos causadores de impacto ambiental.

TABELA 5. Lista de tarefas e responsabilidade para a preparação das audiências públicas referente a empreendimentos causadores de impacto ambiental.

\begin{tabular}{|c|c|}
\hline ATIVIDADES & RESPONSÁVEL \\
\hline Publicação DO & IBAMA \\
\hline Outras publicações & IBAMA/Empreendedor \\
\hline Plano de comunicação e divulgação & Empreendedor \\
\hline Material de divulgação (folhetos, filmes e painéis) & Empreendedor /Consultoria \\
\hline $\begin{array}{l}\text { Convites formais (prefeito, procurador, vereador, lideranças } \\
\text { e outros) }\end{array}$ & Empreendedor \\
\hline Apresentação institucional & Empreendedor \\
\hline Lista de presença de questionamentos & Empreendedor \\
\hline INFRAESTRUTURA & \\
\hline Infraestrutura (projeção, iluminação, som e gravação) & Empreendedor \\
\hline Microfones sem fio (plenário) & Empreendedor \\
\hline Microfones para a mesa & Empreendedor \\
\hline Recepção & Empreendedor \\
\hline Exposição da documentação (EIA/RIMA) & Consultoria \\
\hline Back-up de equipamentos & Empreendedor \\
\hline Gerador de emergência & Empreendedor \\
\hline $\begin{array}{l}\text { Equipe de apoio (recepcionista, responsável, pela } \\
\text { elaboração da ata, segurança, garçom, cerimonialista, } \\
\text { coffee-break }\end{array}$ & Empreendedor \\
\hline Transporte da equipe técnica para o local da AP & Empreendedor \\
\hline \multicolumn{2}{|l|}{ PREPARAÇĀO E TREINAMENTO } \\
\hline Preparação do apresentador do empreendimento & Empreendedor \\
\hline Preparação do apresentador do EIA & Empreendedor/Consultoria \\
\hline Preparação de pessoal de apoio técnico & Empreendedor \\
\hline $\begin{array}{l}\text { Preparação de pessoal de apoio (recepção, apoio, projeção, } \\
\text { som, iluminação, gravação, assessoria de comunicação, } \\
\text { ateiro) }\end{array}$ & Empreendedor \\
\hline Empreendedor & Empreendedor \\
\hline $\begin{array}{l}\text { Preparação de segurança estratégica (monitoração de } \\
\text { grupos de oposição) }\end{array}$ & Empreendedor \\
\hline \multicolumn{2}{|l|}{ PREPARAÇÃO TÉCNICA } \\
\hline Regulamento da AP & Empreendedor/IBAMA \\
\hline Cerimonial & Empreendedor/IBAMA \\
\hline
\end{tabular}




\begin{tabular}{l|c} 
Apresentação do empreendimento & Empreendedor/IBAMA \\
Apresentação do EIA & Consultoria \\
$\begin{array}{l}\text { Levantamento de questões polêmicas } \\
\text { Linha estratégica para AP }\end{array}$ & $\begin{array}{c}\text { Empreendedor/Consultoria } \\
\text { Empreendedor/Consultoria/IBAMA }\end{array}$ \\
\hline Fonte: Adaptada de CONAMA 009/87
\end{tabular}

Conforme Martini e Lima, 2015; Villâsboas, 2003; CONAMA (009/87) alguns fatores oferecem obstáculos à participação popular, ao empreendedor e ao andamento da própria audiência como:

- Divulgação, escolha do espaço físico, material de apoio, treinamento de participantes, registro de áudio e vídeo (custas do empreendedor);

- Emprego de linguagem extremamente técnica e intelectual na apresentação do EIA/RIMA;

- Utilização como roteiro de apresentação, uma "cartilha" subscrita pelo empreendedor e entregue a todos os participantes;

- Distanciamento físico e psicológico entre empreendedor e público devido a metodologia empregada na exposição (cartilha, projeção e posicionamento da equipe técnica) determinados pelo órgão licenciador;

- Pode ser formatada com linguagem tendenciosa;

- Pode ressaltar os benefícios do empreendimento;

- Exclusão do debate dos cidadãos pertencentes às classes menos favorecidas, seja intelectual ou economicamente;

- Baixo índice de participação da sociedade civil, seja por meio de perguntas escritas ou orais;

- O público não se dispõe a expressar suas opiniões em um ambiente formal onde a discussão é altamente estruturada.

- Ativistas e frequentadores de audiências públicas;

- Deslocamento dos interessados dos locais de residência, trabalho, estudo e outros (custas do empreendedor);

- Atuação do órgão ambiental licenciador limitada a leitura de dispositivos legais orientadores sobre a forma de realização da audiência pública;

- Utilização de roteiro pré-fixado, inclusive com o estabelecimento e controle de tempos, como regra bastante curtos, para coordenar as falas e ações no decorrer da audiência pública;

- Órgão ambiental/licenciador - amparo legal (interpretação);

- A mesa é ocupada exclusivamente pelo empreendedor, seus consultores e representantes do órgão ambiental;

- Componentes da mesa escolhidos pelo órgão licenciador;

- Atraso nos prazos para a concessão das licenças (cronograma de obras) pelo órgão licenciador;

- Consomem tempo e são caras para todas as partes; 


\subsection{Roteiro de audiência}

No Brasil, como citada anteriormente, a Resolução CONAMA 009/87 determina que os exemplares do EIA e do RIMA devem estar à disposição do público e demais interessados até 15 dias anteriores à realização da audiência pública. Após sua entrega, o órgão ambiental os divulgará em edital e será anunciado pela imprensa local afim de que os interessados convoquem a audiência pública dentro de um prazo de 45 dias corridos (Rocha, 2008).

O art. 2ํㅡㄹ da Resolução CONAMA 001/86 dispõe que o órgão de Meio Ambiente promoverá a realização de audiência pública sempre que julgar necessário, quando for solicitada por entidade civil, pelo Ministério Público, ou por 50 ou mais cidadãos.

Segundo Fink (1995), após receber o requerimento, o órgão ambiental designará data e local (acessível aos interessados). Aberta a audiência, dirigida pelo órgão licenciador, ocorrerá uma exposição objetiva do projeto seguida do Relatório de Impacto Ambiental (RIMA) e de discussões. Após, será lavrada uma ata sucinta da audiência pública acompanhada de todos os documentos que foram entregues e que servirão para a análise e aprovação ou não do órgão licenciador.

As audiências são marcadas preferencialmente à noite para acessar um maior número de participantes e podem durar muitas horas não ultrapassando o período de um dia. Os participantes podem se manifestar oralmente e apresentar documentos e, a cada audiência, que pode ser gravada, é formulada uma ata com as intervenções do público e documentos apresentados (Sanchez, 2010).

Diz o art. 5 da Resolução 009/87 que "a ata da (s) audiência (s) pública (s) e seus anexos servirão de base, juntamente com o RIMA, para a análise e parecer final do licenciador, quanto à aprovação ou não do projeto (Machado, P., 2009, p. 263).

Por vezes, após a realização de audiências públicas ou apresentação de comentários aos estudos, o órgão ambiental conclui que o empreendedor não atende a todas as exigências legais e solicita complementações que não são incorporadas ao RIMA e, consequentemente, não são submetidas à consulta pública, o que poderá intervir na análise daqueles que tiveram como única fonte de informações o RIMA (Barros, 2004).

A Tabela 6 demonstra as responsabilidades do órgão licenciador e do empreendedor no que se refere à publicidade do processo de licenciamento. 
TABELA 6. Publicidade nas etapas do Licenciamento Ambiental.

\begin{tabular}{ll}
\multicolumn{1}{c}{ Publicidade } & Responsável \\
\hline Acesso à informação (sistematização, transparência, educação, etc.) & Poder Público \\
Publicação do requerimento de LP & Empreendedor \\
\hline Disponibilização do EIA/RIMA durante o período de análise & IBAMA \\
\hline $\begin{array}{l}\text { Publicação do chamado para audiência pública } \\
\text { Divulgação e discussão do RIMA - AUDIÊNCIA PÚBLICA }\end{array}$ & IBAMA \\
\hline Publicação de LP (deferimento, indeferimento, renovação, retificação) & Empreendedor \\
Publicação do requerimento de LI & Empreendedor \\
\hline Publicação de LI (deferimento, indeferimento, renovação, retificação) & Empreendedor \\
Publicação do requerimento de LO & Empreendedor \\
\hline Publicação LO (deferimento, indeferimento, renovação, retificação) & Empreendedor \\
\hline
\end{tabular}

Fonte: Adaptada de Barros, 2004.

Em outros países como no Canadá (Quebec), não existe um procedimento formal para a Avaliação de Impacto Ambiental, no entanto, o BAPE (Bureau d'Audiences Publiques sur l'Environnement) um órgão independente foi criado em 1978 com a função de promover audiências públicas e que busca soluções alternativas mais adaptadas às necessidades e expectativas da população (Gauthier, Simard e Waaub, 2011).

Cabe ressaltar que existem algumas diferenças entre o Brasil e o Canadá no que se refere às audiências públicas. Enquanto no Brasil dependem da autorização do órgão licenciador, no Canadá, essa competência deve-se ao Conselho de Ministros. O BAPE (Bureau d'Audiences Publiques sur l'Environment) possui um período de quatro meses para realizar as audiências que dividem-se em duas partes com intervalo de 21 dias entre elas (Sanchez, 2010, p. 421).

A Tabela 7 demonstra as fases de condução de audiência pública em Quebec, no Canadá em comparação com as audiências realizadas no caso de empreendimentos causadores de impacto ambiental ou de degradação ambiental.

TABELA 7. Etapas para condução de audiências públicas em Quebec, Canadá Etapas do processo de consulta

1. Requerimento por parte de cidadãos ou associação ao ministro do Meio Ambiente para realização de audiência pública para discussão do projeto.

2. Após o pedido ser aceito, o Presidente do escritório de audiências públicas, o BAPE nomeia uma comissão de consulta.

3. Publicação da audiência em jornais e internet.

4.Realização de reuniões preparatórias com o proponente do projeto e requerente da audiência.

5. Primeira parte da audiência (audição/informação sobre o projeto):

Explicações preliminares pela comissão de consulta;

Explanação dos requerentes sobre o motivo de requisição da audiência; 
Apresentação do EIA pelo proponente;

Depoimentos de outras pessoas;

Colocação do público (questões);

6. Encaminhamento de documentos e relatórios para as prefeituras.

7. Segunda parte da audiência (perguntas, críticas e opiniões):

a) Pronunciamentos de associações ou cidadãos que apresentaram documentos;

b) A comissão de consulta ouve ou dirige perguntas ao proponente do projeto e ao requerente da audiência pública.

8. Preparação do relatório final da comissão de consulta com o ministro do Meio Ambiente

9. Publicação, divulgação e disponibilização do relatório final ao público (síntese de opiniões recolhidas e algumas recomendações.

Fonte: Adaptada de Sanchez, 2010; Gauthier et al.,2011.

Na Hungria, foi publicado em 1995 um Decreto (152/95), que requer a apresentação de um Estudo de Impacto Ambiental Preliminar (PEIS), pela Inspeção Ambiental onde autoridades especializadas determinam se é necessária a elaboração de um Estudo de Impacto Ambiental Detalhado (DEIS), enquanto que os comentários do público são enviados ainda no processo de PEIS.

Após a apresentação do DEIS, uma audiência pública é realizada onde conta com a notificação (procedimento que substituiu os meios de comunicação em massa) e a participação das autoridades especializadas, do proponente, da população afetada e das autoridades locais. A decisão final da Inspeção Ambiental ocorre por meio dos dados coletados e da decisão das autoridades especializadas (Palerm,1999).

No Brasil, as etapas das audiências públicas são determinadas pela Resolução CONAMA 009/87 e estão sumarizadas no diagrama esquemático mostrado na Fig. 10. 


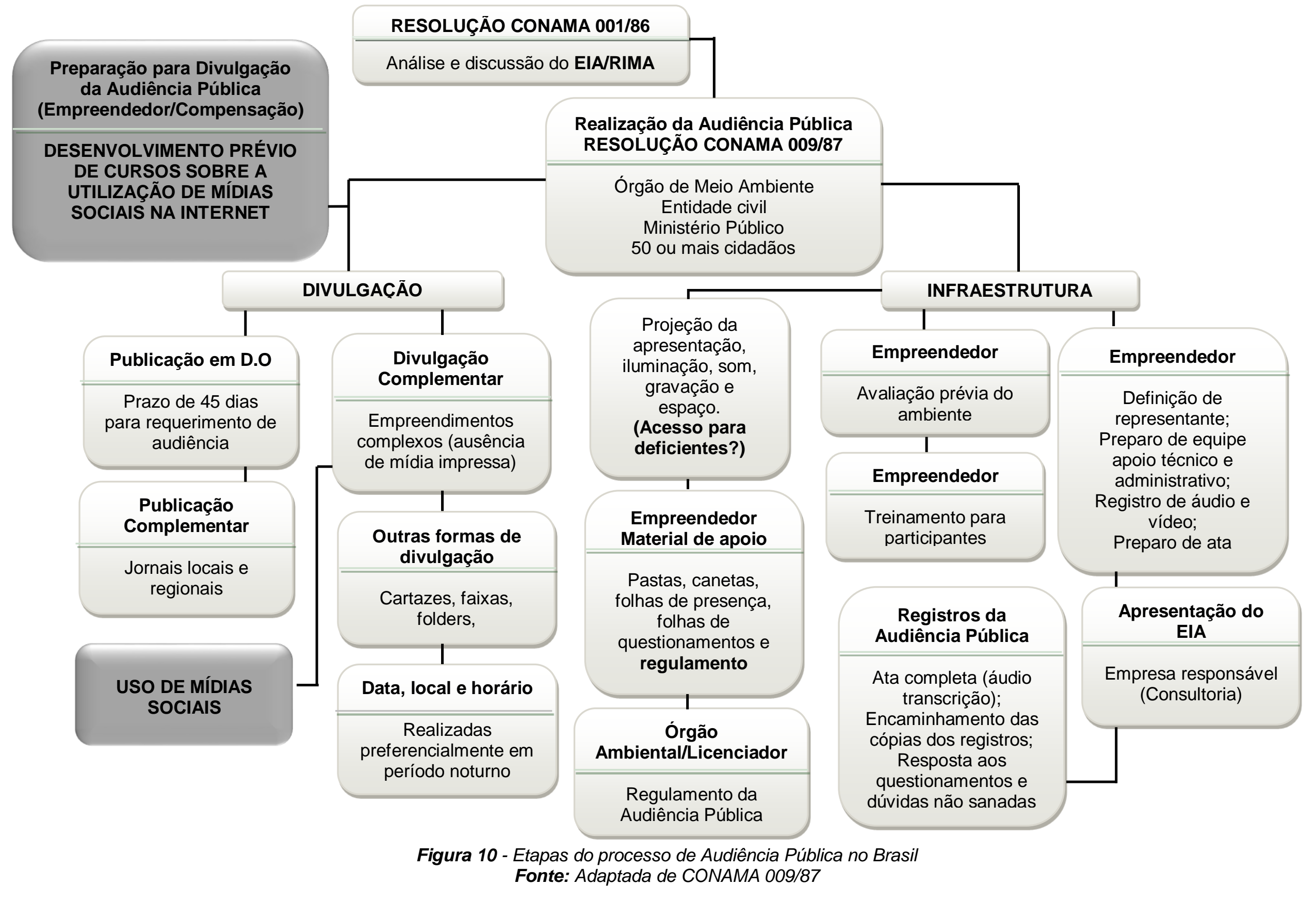




\section{METODOLOGIA}

Para a consecução do objetivo deste trabalho foi adotado o método qualitativo de comparação de procedimentos e resultados obtidos no licenciamento ambiental em outros países, especificamente no que diz respeito às audiências públicas.

Para isso foi realizado um estudo da Legislação Brasileira e Leis pertinentes para ser comparada com a de outros países, onde o roteiro fornecido pelo IBAMA, baseado na Resolução CONAMA 09/1987, também foi tomado como referência para efeito de comparação.

Também foram avaliadas as ferramentas usadas para a divulgação das audiências públicas e, além disso, sugeriu-se facilitar o entendimento do público de interesse fazendo uso dos recursos tecnológicos e mídias sociais atualmente existentes, e sua disponibilização em locais de fácil acesso à população, como escolas ou centros de ensino, associações, centros de cultura e lazer e outros.

Dentro desse escopo, foi feita uma avaliação crítica sobre os mecanismos de compensação adotados, quando a construção de instalações nucleares já se apresenta como um retorno sócio/econômica/ambiental para a população brasileira, haja vista serem estas atividades um monopólio da União. 


\section{RESULTADOS E DISCUSSÃO}

Alguns juristas, afirmam que a licença ambiental teria a natureza jurídica de autorização e não propriamente de licença, dessa forma, a maior parte da doutrina entende que a licença ambiental consiste, de fato, numa licença, ou seja, ela não pode ser negada ao empreendedor se forem satisfeitos todos os requisitos legalmente exigidos ao empreendimento proposto (Machado, P. 1999 apud Araújo, S., 2002).

É fato que o EIA/RIMA é de relevante importância para o trabalho dos órgãos licenciadores para a concessão de licenças ambientais e no que se refere a negociação das partes envolvidas, porém, tem contribuído de forma pouco eficaz na gestão do meio ambiente, e assim, a audiência pública perde sua finalidade que é contar com a participação social na tomada de decisão quanto ao licenciamento de atividades causadoras de grande impacto ambiental

A resolução CONAMA oㅡ 237/97 diferencia licenciamento de licença ambiental, onde o primeiro é o procedimento administrativo onde o órgão ambiental licencia a localização, instalação, ampliação e operação de empreendimentos e atividades que utilizam recursos naturais e são efetivamente poluidoras, ou ainda, que possam causar degradação ambiental, já a licença é um ato administrativo onde são estabelecidas condições, restrições, e medidas de controle ambiental que devem ser seguidas pelo responsável pelos empreendimentos ou atividades sujeitas ao licenciamento (Trennepohl, 2010).

Segundo Santoro (2014), o licenciamento ambiental é extremamente burocrático, uma única licença pode levar em torno de sete anos para ser emitida. Do ponto de vista econômico, a perda financeira de um projeto paralisado por ser incalculável e esse prejuízo acaba sendo transferido para dentro do preço do serviço a ser produzido. A grande ironia, é que após a concessão da licença, não há fiscalização nas obras. O normal seria a licença ambiental ser rapidamente concedida e a fiscalização ser atuante e de periodicidade constante, o qual seria o real objetivo desse processo. 
Essa falta de fiscalização está relacionada à deficiência na estrutura dos órgãos ambientais responsáveis, o que envolve não só o IBAMA, mas as secretarias municipais e estaduais. As licenças são concedidas se houver 0 cumprimento das condicionantes com o objetivo de remediar futuros danos, mas, se não houver fiscalização, todo o processo de licenciamento se perde (Diário do Comércio e Indústria, 2015).

Para Peduzzi (2016), um exemplo das consequências da falta de fiscalização foi o rompimento da barragem de rejeitos da SAMARCO, da VALE e da BHP, ocorrido em 05/11/2015, e que comprometeu a integridade de todo o Vale do Rio Doce a partir do Município de Bento Rodrigues.

É visível a necessidade e a obrigatoriedade de adoção de audiências públicas, sempre que esse for o melhor caminho para fiscalizar as obras, isto aferido em critérios técnicos e não político-partidários, como forma de melhor preservar o interesse público e os interesses dos cidadãos por meio da participação da sociedade nas decisões sobre políticas públicas em todos os níveis e esferas de governo, sobretudo na área ambiental (Barros, 2004, p. 172).

A grande demanda por projetos de infraestrutura no país transformou 0 licenciamento ambiental em um obstáculo para o avanço das obras gerando atrasos que podem levar anos. Inclusive, os empresários, acusam o governo de incluir no licenciamento obrigações sociais que deveriam ser atendidas pelo poder público e não pelas empresas, os chamados planos de compensação que em nada se relacionam a resolução de problemas urbanos pelo empreendedor (Borges, 2014).

Uma outra situação a ressaltar, se refere ao então presidente Luiz Inácio Lula da Silva que não escondeu sua irritação com o IBAMA no processo de licenciamento ambiental das usinas hidrelétricas de Santo Antônio e Jirau no Rio Madeira em Roraima. A demora na concessão da licença ambiental ocorreu durante as obras das usinas pelo fato das mesmas impedirem a migração de peixes como o bagre.

O mesmo presidente voltou a reclamar dos atrasos em grandes obras como o que ocorreu no caso da construção do viaduto no Rio Grande do Sul que liga a BR-101 a Argentina devido a descoberta de uma perereca durante o processo de licenciamento. Para descobrirem se a perereca estava em extinção, a obra ficou atrasada em sete meses, sendo que essa situação já deveria ter sido identificada 
durante a elaboração do EIA/RIMA. Segundo ele, o país passou mais de 25 anos sem investimento porque foi criada uma poderosa máquina de exigências extremamente burocrática que é superior à máquina de produção (Leal, 2007; Rangel, 2009).

Diante de situações como essas, Borges (2014) afirma que o governo pretende alterar as regras do licenciamento ambiental para garantir mais agilidade e transparência na emissão de licenças, o que depende de um entendimento entre o Ministério do Meio Ambiente (MMA) e o IBAMA. A própria ministra do Meio Ambiente, Izabella Teixeira, acredita não entender como um estudo de impacto ambiental pode ter 35 mil páginas como o do licenciamento da usina hidrelétrica e Belo Monte, em construção no Rio Xingu, Pará.

De acordo com as regras atuais, cabe ao órgão licenciador, no caso de instalações nucleares, o IBAMA, após as audiências públicas, definir se a instalação é ambientalmente viável ou não.

Mesmo que outros órgãos, entre eles, o IPHAN, a Fundação Palmares a FUNAI, algumas Organizações não governamentais (ONG's), a própria comunidade de entorno, possam ser contrários, cabe ao órgão ambiental a decisão final baseada nos documentos e argumentos apresentados durante as audiências públicas.

Dessa forma, essas reuniões, no Brasil, deixam de atingir seu objetivo e passam a assumir caráter compensatório, onde a instalação de alguns empreendimentos só é aceita se forem realizadas benfeitorias para a população ou para o próprio município.

Outra falácia diz respeito às exigências feitas pelo IBAMA para as audiências públicas. A ampla publicidade que deve ser dada a esses eventos ignora a realidade nacional onde talvez a mais importante seja a existência e o uso da telefonia móvel, um meio que propicia agilidade e melhor comunicação entre as pessoas, permitindo assim que os avisos sobre esses eventos sejam transmitidos mais rapidamente, no caso das audiências públicas, é uma forma de abranger um grande número de pessoas interessadas nesse processo. Segundo dados da própria ANATEL, até janeiro de 2016, existiam no Brasil 257,25 milhões de linhas telefônicas móveis, sendo 25,44 milhões delas, dotadas de serviços de comunicação multimídia (smartphones) (ANATEL, 2016). 
Já o aplicativo WhatsApp, amplamente utilizado atualmente como uma forma rápida e eficaz de comunicação, segundo dados do G1, alcançou em 2016, a marca de 1 bilhão de usuários no mundo todo, sendo somente no Brasil, aproximadamente 100 milhões de usuários $(G 1,2016)$.

Este aplicativo permite a formação de grupos com número ilimitado de participantes, o que se adequaria ao propósito de divulgação e discussão de interesse de audiência pública. 


\section{CONCLUSÕES}

A organização de audiências públicas é precedida da elaboração do EIA e seu respectivo RIMA, porém, isso não impede o surgimento de inúmeras dificuldades decorrentes das exigências feitas pelo órgão licenciador, o IBAMA, no caso das instalações nucleares.

Como cabe a esse órgão a competência de licenciar essas instalações, muitas vezes são exigidas ações, tão burocráticas, que ultrapassam a capacidade do empreendedor, e, ao mesmo tempo é permitido ao órgão licenciador uma demora considerável na concessão das licenças mesmo que o prazo para que esse órgão se manifeste esteja previsto no art. 14 do CONAMA 237/97, ou seja, um prazo de 12 meses para empreendimentos instruídos pelo EIA/RIMA.

A demora na emissão das licenças compromete a execução do cronograma físico/financeiro do empreendimento, podendo, inclusive, afetar a liberação de recursos junto a órgãos de fomento. A descontinuidade no fluxo orçamentário chega a ocasionar a desmobilização de equipes de trabalho com graves consequências para o capital intelectual mobilizado, e, tratando-se de instalações nucleares a mão-de-obra para elaboração do projeto sempre tem como característica um alto grau de especialização.

Além desses fatores, a aceitação do público frente a um empreendimento nuclear, é grande geradora de conflitos e está diretamente relacionada ao potencial de risco que essas instalações oferecem, mas, a população de entorno, tende a minimizá-los caso haja em troca, benefícios oferecidos pelo empreendedor.

Dessa forma, aspectos como clareza e objetividade na comunicação são extremamente relevantes e, quando bem fundamentadas levam a uma boa aceitação pelo público envolvido, sendo de extrema importância que as comunidades dos locais escolhidos sejam consultadas de forma frequente ao longo de todo o processo. 
A avaliação do modelo de audiência pública para o licenciamento de instalações nucleares permitiu, portanto, a análise de suas etapas apresentando como destaque, o uso da tecnologia disponível como as mídias sociais (blogs, redes sociais, ferramentas de troca de vídeos, ferramentas de discussão e outras), um meio que propicia uma melhora na comunicação entre os diversos tipos de pessoas, podem ser acessadas em vários locais e promove a interação social criando laços associativos e relacionais.

A utilização dessas mídias acaba, portanto, garantindo uma diminuição dos custos da audiência e mais agilidade com os prazos e otimização dos processos de maneira que as licenças não sejam negadas se forem satisfeitos todos os requisitos legalmente exigidos para o empreendimento proposto, tornando mais eficiente os processos de licenciamento para as instalações nucleares no Brasil.

O uso da internet permite a disseminação de informações e a instalação de aplicativos como por exemplo o Periscope e o uso de web rádio e web TV facilitará e permitirá o acesso às audiências públicas evitando o deslocamento das pessoas de seus locais de trabalho, estudo e residências, assim como resguarda o empreendedor da responsabilidade de disponibilizar transporte e lugares devidamente adequados para que os participantes tenham acesso aos locais onde serão realizadas as audiências. Além disso, existe a possibilidade de se gravar e disponibilizar para o público o conteúdo de toda a audiência.

O empreendedor, tão cobrado pelo órgão licenciador para a implementação de planos de compensação, pode desenvolver cursos em escolas ou centros de ensino, associações, centros de cultura e lazer para o uso adequado das mídias sociais e de aplicativos associados a elas, alcançando com isso um maior número de pessoas. O simples uso de um celular possibilita um alcance maior, haja vista ele poder abrigar todas as demais mídias: televisão, rádio e jornais. Esses sistemas tornam possível o cadastramento prévio das pessoas que participarão das audiências, que podem ser avisadas sobre suas ocorrências através de WhatsApp, um aplicativo que favorece a formação de grupos para a troca de dúvidas, de informações e mensagens de texto (SMS) ou até mesmo email.

O cidadão sabendo fazer uso desses recursos pode obter qualquer tipo de informação sobre o empreendimento, não só as que são colocadas à sua 
disposição pelo empreendedor, como as que podem ser obtidas fazendo uso dos mecanismos de busca ou já disponíveis nas redes sociais.

O desenvolvimento de fóruns para o esclarecimento de dúvidas também é algo a ser explorado e eficaz para a atividade proposta, fornecendo ao público todas as informações pertinentes ao processo e atendendo à população em suas preocupações, inclusive no que se refere aos assuntos não técnicos.

Da forma como está proposta pelo IBAMA, a organização da Audiência Pública é uma tutela da sociedade, uma vez que as formas de manifestação, assim como o teor das mesmas, estão previamente definidas no roteiro a ser seguido pelo empreendedor.

Finalmente, é importante que o órgão de licenciamento ambiental perceba que a construção de instalações nucleares se constitui em uma ação de estado para atender às demandas da sociedade brasileira, que dentre todas as formas de geração de energia, a nuclear tem maior rendimento, os resíduos gerados são de fácil transporte, não são emissores de poluentes, a tecnologia adotada é totalmente controlada, há rigorosa segurança quanto aos riscos oferecidos e são de grande importância para a aplicação principalmente na área da saúde, será difícil avançar mais rápido.

A diminuição do custo de organização da audiência pública, assim como a inclusão digital da população de entorno do empreendimento já seriam suficientemente interessantes para que fosse reformulado o roteiro elaborado pelo IBAMA para o licenciamento ambiental de instalações nucleares.

Na Fig. 11 são apresentadas as contribuições desse trabalho ao modelo de audiência pública existente no Brasil e que seguem instruções do órgão licenciador, no caso das instalações nucleares, o IBAMA. 


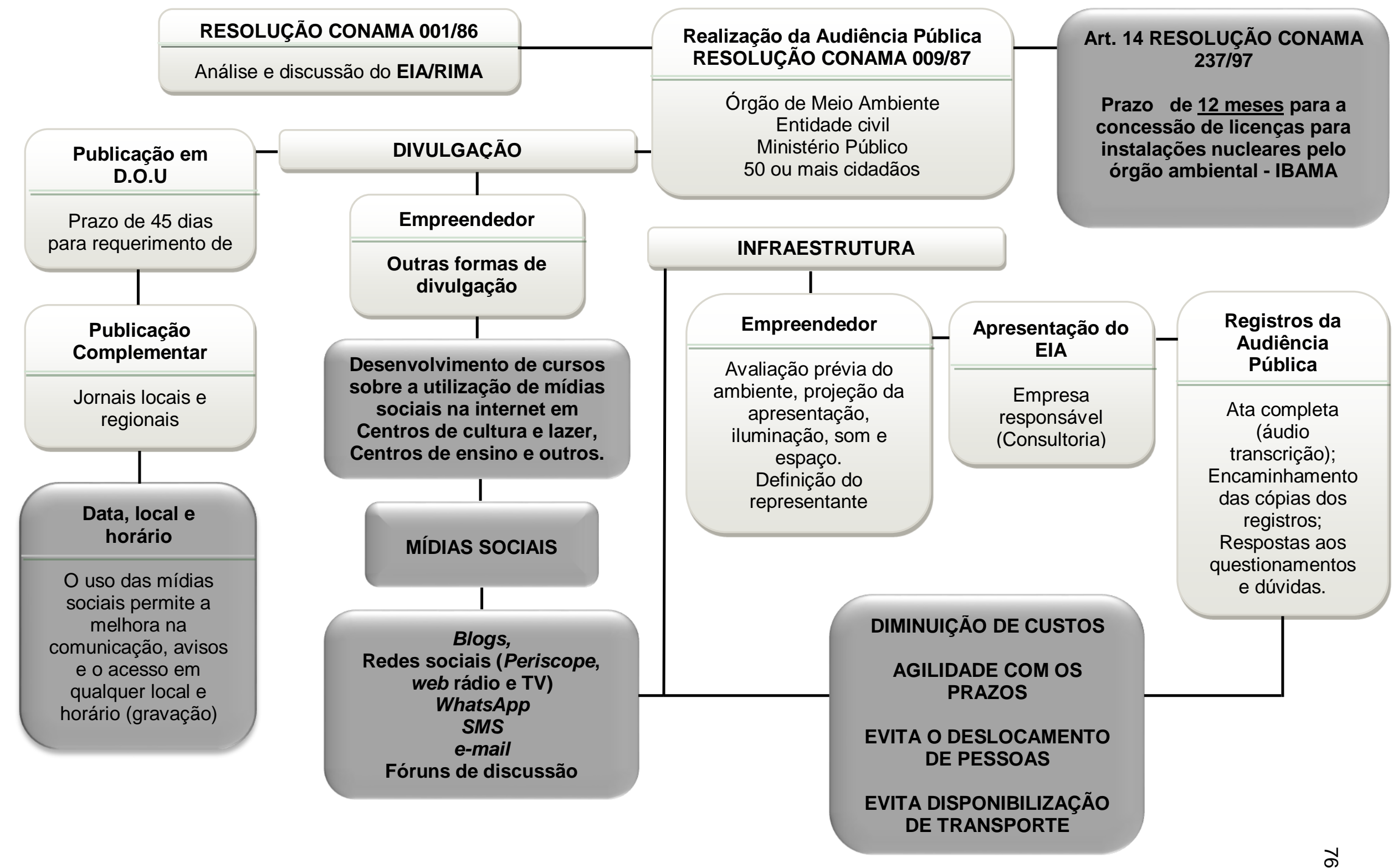

Figura 11. Contribuições para o modelo de audiência pública para instalações nucleares no Brasil segundo o IBAMA Fonte: Adaptado de CONAMA 009/87 


\section{REFERÊNCIAS BIBLIOGRÁFICAS}

ALMEIDA, I.P.S (Org.) Projeto Comunicação e Interação com a Sociedade Projeto CIS. Rio de Janeiro: IPEN, 2010.

AMANTÉA, F.N.; MESQUITA, A. Z. A Nova Geração dos Reatores Nucleares Estado da Arte e Tendência, com Ênfase na Economia, Segurança e Proteção. In: II SENCIR - SEMANA DE ENGENHARIA NUCLEAR E CIÊNCIAS DA RADIAÇÕES. - Escola de Engenharia - UFMG de 07 a 09 de outubro de 2014. Belo Horizonte. Disponível em: http://www.sencir.nuclear.ufmg.br/assets/RN 13.pdf . Acesso em: 06/11/2014.

AMARAL, J.C.B.S. Recuperação de tório e urânio a partir do licor gerado no processamento da monazita pela INB/Caldas, MG, via extração por solventes. 2006. Dissertação (Mestrado) - Comissão de Tecnologia Nuclear, Belo Horizonte.

AGÊNCIA NACIONAL DE TELECOMUNICAÇÕES - ANATEL. Disponível: www.anatel.gov.br/institucional/index.php/noticias/noticia-dados-01 Acesso em: 30/03/2016.

ANTUNES, P. B. Direito Ambiental. Rio de Janeiro: Lumen Juris, 1996.

ANTUNES, P. B. Direito Ambiental. Rio de Janeiro: Lumen Juris, 2008.

AQUINO, A.R. Fundamentos de Tecnologia Nuclear - Materiais e ciclo do combustível nuclear - TNM 5788 - Instituto de Pesquisas Energéticas e Nucleares (IPEN/CNEN-SP) Divisão de Ensino, 2012.

ARAÚJO, E. B; LAVINAS, T. COLTURATO, M.T; MENGATTI, J. Garantia de qualidade aplicada à produção de radiofármacos. Rev. Bras. Cienc. Farm. São Paulo, v.44, n.1, p. 1-12, jan/mar., 2008.

ARAÚJO, S.M.V.G. Licenciamento ambiental e legislação. Consultoria Legislativa. Brasília, Distrito Federal, set. 2002.

ARIAS, M.E.L.F. Manual de tecnologia nuclear para periodistas. 2004. Disponível em: <http://www.foronuclear.org/es/publicaciones-ydocumentacion/publicaciones/manual-de-tecnologia-nuclear-para-periodistas $>$.

Acesso em: 06/11/2014.

AUSTRALIAN NUCLEAR SCIENCE AND TECHNOLOGY ORGANISATION ANSTO - OPAL Research Reactor. Disponível em: $<$ http://www.ansto.gov.au/AboutANSTO/OPAL/>. Acesso em: 17/02/2015. 
BAPTISTA, B. G.L. Oralidade no Direito Administrativo: licenciamento ambiental e audiência pública. v.30, p. 09-10, 2007.

BARBIERI, J.C. Avaliação de impacto ambiental na legislação brasileira. Revista de Administração de Empresas de São Paulo (RDAE). São Paulo, v. 35, n. 2, p, 78-85 mar/abr. 1995.

BARBIERI, J.C. Gestão Ambiental Empresarial: Conceitos, Modelos e Instrumentos. São Paulo: Saraiva, 2004.

BARBOSA, E. M. Direito ambiental e dos recursos naturais: Biodiversidade, petróleo e água. Belo Horizonte: Fórum, 2011.

BARROS, L.V. A efetividade do direito à informação ambiental. Dissertação (Mestrado). 2004. Universidade de Brasília, Distrito Federal.

BASSO, L.A; VERDUM, R. Avaliação de Impacto Ambiental: EIA e RIMA como instrumentos técnicos e de gestão ambiental. In: VERDUM, Roberto; MEDEIROS, VIEIRA, R.M. (Org.). RIMA - Relatório de impacto ambiental: legislação, elaboração e resultados. 5ed. Porto Alegre: Ed. da UFRGS, 2006, p.73-80.

BEIERLE, T.C. Public Participation in Environmental Decisions: An Evaluation Framework Using Social Goals. Resources for the Future, p. 99-106, 1998.

BODANSKY, D. Nuclear energy: principles, practices, and prospects. 2 ed. New York: Springer, 2004.

BORGES, A. Licenciamento ambiental vai mudar. O Estado de São Paulo, São Paulo, 03 ago. 2014. Disponível em: $<$ http://economia.estadao.com.br/noticias/geral,licenciamento-ambiental-vaimudar-imp-,1538080 > Acesso em: 23/05/2015.

BRASIL. Constituição (1988). Constituição da República Federativa do Brasil. Brasília, DF: Senado 1988.

CADERNO DE LICENCIAMENTO AMBIENTAL. Programa Nacional de Capacitação de Gestores Ambientais: licenciamento ambiental Ministério do Meio Ambiente. Brasília: MMA, 2009. Disponível em: $<$ http://www.mma.gov.br/estruturas/dai pnc/ arquivos/pnc caderno licenciament o ambiental 01 76.pdf $>$ Acesso em: 10/08/2015.

CARVALHO, J. F. O espaço da energia nuclear no Brasil. Estudos avançados. São Paulo, v. 26, n. 74, p. 293-307, 2012. 
CASTRO, D.I.M. O licenciamento ambiental e seus conflitos. 2006. Dissertação (Mestrado) - Universidade Católica de Santos, Santos.

CENTRO DE TECNOLOGIA MINERAL - CETEM. Terras Raras. Rio de Janeiro, 2008. Disponível em: <http://www.cetem.gov.br/publicacao/CTs/CT2008-18800.pdf> Acesso em: 07/07/2014.

CHMIELEWSKI, A. G. Chemistry for the nuclear energy of the future. NUKLEONIKA. Warsaw, Poland, v. 56, n. 3, 241-249, 2011.

COMISSÃO NACIONAL DE ENERGIA NUCLEAR - CNEN. Energia Nuclear Disponível em: <http://www.cnen.gov.br/ensino/apostilas/energia.pdf>. Acesso em: 01/07/2014.

COMISSÃO NACIONAL DE ENERGIA NUCLEAR - CNEN. Norma CNEN-NN8.01; Gerência de Rejeitos Radioativos de Baixo e Médio níveis de Radiação. Disponível em: <http://www.cnen.gov.br/seguranca/normas/pdf/Nrm801.pdf > Acesso em: 18/04/2015.

COMISSÃO NACIONAL DE ENERGIA NUCLEAR - CNEN. Norma CNEN-NN8.02; Licenciamento de Depósitos de Rejeitos Radioativos de Baixo e Médio níveis de Radiação. Disponível: $<$ http://www.cnen.gov.br/seguranca/normas/pdf/Nrm802.pdf> Acesso em: 18/04/2015.

COMISSÃO NACIONAL DE ENERGIA NUCLEAR - CNEN. Requisitos de Radioproteção e Segurança para Serviços de Medicina Nuclear. CNEN-NE-3.05; 2013. Requisitos de segurança e proteção radiológica para serviços de medicina nuclear. Disponível em $<$ http://www.cnen.gov.br/seguranca/normas/pdf/Nrm305.pdf> Acesso em: $15 / 08 / 2014$.

CONGRESSO NORTE NORDESTE DE QUÍMICA. I, 2007, Natal. Radiações Nucleares: Histórico e Aplicação Industrial na Preservação de Alimentos... Natal: UFRN, 2007. Disponível em: $<$ http://www.annq.org/congresso2007/trabalhos apresentados/T41.pdf> Acesso em: 24/03/2014.

CONSELHO NACIONAL DO MEIO AMBIENTE - CONAMA. Legislação Ambiental. Disponível em: <http://www.mma.gov.br/port/conama/>. Acesso em 02/06/2013.

CONSELHO NACIONAL DO MEIO AMBIENTE - CONAMA. Resoluções e outros atos. Disponível em: $<$ http://www.mma.gov.br/port/conama/legiabre.cfm?codlegi=60 $>$. Acesso em $11 / 03 / 2015$. 
CUNHA, S.B; GUERRA, A.J.T. (Org.) Avaliação e Perícia Ambiental. Rio de Janeiro: Bertrand Brasil, 2012.

DEUTCH, J. M.; MONIZ, E. J. Opção Nuclear, Scientific American Brasil, v. 3, n. 53, p. 46-51, out. 2006.

DEUTCH, J.M.; FORSBERG, C.W.; KADAK, A.C.; KAZIMI, M.S.; MONIZ, E.J.; PARSONS, J.E. Future of Nuclear Power Study. Update of the MIT, (Massachusetts Institute of Technology), 2003. Disponível em: http://www.tuumajaam.ee/public/documents/MIT nuclearpower-update2009.pdf Acesso em: 22/02/2015.

Sem fiscalização após licenciamento, benefício ambiental pode ser limitado. Diário Comércio Indústria \& Serviços. Disponível em: http://www.dci.com.br/legislacaoe-tributos/sem-fiscalizacao-apos-licenciamento,--beneficio-ambiental-pode-serlimitado-id471780.html $>$ Acesso em: 02/02/2016.

DOMINGUES, J.M.; CARNEIRO, J.S.A. A compensação ambiental prevista pelo Sistema Nacional de Unidades de Conservação (SNUC): A ADI no 3.378 e o Decreto 6.848/09. Revista Direito GV. v. 6, n. 2, p. 493-502, jul/dez. 2010.

DUDERSTADT, J. J.; HAMILTON, L. J. Nuclear Reactor Analysis. New York: John Wiley, 1976.

\section{ELETRONUCLEAR. Relatório de Impacto Ambiental (RIMA) da Unidade Central 3 Almirante Álvaro Alberto. Disponível em: http://www.eletronuclear.gov.br/Portals/0/RIMAdeAngra3/03 caracterizacao.html Acesso em: 22/04/2013.}

ESCOLA JUDICIAL DES. EDÉSIO FERNANDES. Cadernos da EJEF: Série Estudos Jurídicos: Direito Ambiental - n. 1. Belo Horizonte, Minas Gerais, 2004. Disponível em: http://www.ejef.timg.jus.br/home/index2.php?option=com content\&do $\mathrm{pdf}=1$ \&id=1 46. Acesso em: 01/04/2015.

EUROPEAN NUCLEAR SOCIETY - ENS. Boiling Water Reactor. Disponível em: http://www.euronuclear.org/info/encyclopedia/boilingwaterreactor.htm Acesso em: 05/01/2015.

FERNANDES, B.R. Novo paradigma da comunicação para licenciamentos ambientais. 2000. Tese (Doutorado) - Universidade de São Paulo, São Paulo.

FERREIRA, V.V.M; SOARES, W.A. Insucessos em empreendimentos nucleares devido a falhas em processos de Comunicação Pública. Intercom - RBCC. v.35, n.2, p.313-329, jul/dez 2012. 
FIGUEIRA, R.C.L; CUNHA, I.I.L. A contaminação dos oceanos por radionuclídeos antropogênicos. Química Nova, São Paulo, v.21 n.1, p. 73-77, jan/fev. 1998.

FIGUEIREDO, L. V. Instrumentos da Administração Consensual: A audiência pública e sua finalidade. Revista Eletrônica de Direito Administrativo Econômico (REDAE), Salvador - Bahia, n. 11, 1-16, 2007.

FINK, D.R. Audiência Pública em Matéria Ambiental no Direito Brasileiro. Justitia, São Paulo, v. 57, n. 169, p. 60- 64. jan/mar. 1995.

FIORILLO, C.A.P. Curso de Direito Ambiental Brasileiro. São Paulo: Saraiva, 2013.

GAUTHIER, M.; SIMARD, L.; WAAUB, J.P. Public participation in strategic environmental assessment (SEA): Critical review and the Quebec (Canada) approach. Environmental Impact Assessment Review. Quebec, Canadá v.31, p. 48-60, 2011.

GUIMARÃES, L. S; MATTOS, J.R.L A contribuição da opção nuclear numa economia menos dependente do carbono. In: GOLDEMBERG, J. (Coord.) Energia Nuclear e Sustentabilidade. São Paulo: Blucher, 2010, p. 17- 61.

GOLDBERG, S.M; ROSNER, R. Nuclear Reactors: Generation to Generation. American Academy of Arts \& Sciences, Cambridge, MA. mar/2011.

GONÇALVES, O.D; ALMEIDA, P.S. A. Energia Nuclear. Ciência Hoje, São Paulo, v.37, p. 36-44, out/2005.

HANNUM, H. W.; MARSH, E. G.; STANFORD, S. G. Lixo Nuclear, Scientific American Brasil, v. 2, n. 42, p. 76-81, mar/2006.

INSTITUTO DE ENGENHARIA NUCLEAR - IEN. Recebimento de Rejeitos Radioativos. Disponível em: <http://www.ien.gov.br/produtos/recrej.php $>$. Acesso em: 10/03/2015.

INDÚSTRIAS NUCLEARES DO BRASIL - INB. Licenciamento. Disponível em: $<$ http://www.inb.gov.br/pt-br/WebForms/interna2.aspx?secao id=67>. Acesso em: 02/06/2013.

INSTITUTO BRASILEIRO DO MEIO AMBIENTE E RECURSOS NATURAIS RENOVÁVEIS - IBAMA. Licenciamento Ambiental Federal. Disponível em: $<$ http://www.ibama.gov.br/licenciamento/. Acesso em: 31/03/2013. 
INSTITUTO BRASILEIRO DO MEIO AMBIENTE E RECURSOS NATURAIS RENOVÁVEIS - IBAMA. Tabela e Fórmulas de Cálculos - Procedimentos. Disponível em: <http://ibama.gov.br/procedimentos/tabelas-e-formula-de-calculo- $>$. Acesso em: 01/06/2015.

INSTITUTO BRASILEIRO DO MEIO AMBIENTE E RECURSOS NATURAIS RENOVÁVEIS - IBAMA. Ibama define procedimentos para o licenciamento de instalações radioativas. Disponível em: http://www.ibama.gov.br/publicadas/ibama-define-procedimentos-para-olicenciamento-de-instalacoes-radioativas Acesso em: 24/02/2016.

INSTITUTO ESTADUAL DO AMBIENTE - INEA. EIA/RIMA. Disponível em: $<$ http://www.inea.ri.gov.br/fma/eia rima apresentacao.asp $>$. Acesso em: $22 / 04 / 2013$.

INSTITUTO DE PESQUISAS ENERGÉTICAS E NUCLEARES - IPEN. IPEN e CENA-USP desenvolvem projeto conjunto para esterilização do Aedes aegypti com radiação nuclear. Disponível em: < https://www.ipen.br/portal por/portal/interna.php?secao id=38\&campo=5786> Acesso em: 17/02/2016.

INSTITUTO DE RADIOPROTEÇÃO E DOSIMETRIA - IRD. O que são rejeitos radioativos?

Disponível:

$<$ http://www.ird.gov.br/index.php?option=com content\&view=article\&id=60> Acesso em: 19/03/2015.

INTERNATIONAL ATOMIC ENERGY AGENCY - IAEA. Nuclear Power. Disponível em: <http://www.iaea.org/NuclearPower/> Acesso em: 09/07/2014.

INTERNATIONAL ATOMIC ENERGY AGENCY - IAEA. Nuclear Share of Electricity Generation. Disponível em: $<$ https://www.iaea.org/PRIS/WorldStatistics/NuclearShareofElectricityGeneration.a spx> Acesso em: 11/02/2015.

INTERNATIONAL ATOMIC ENERGY AGENCY - IAEA. Operational Reactors. Disponível em: $<$ https://www.iaea.org/PRIS/WorldStatistics/OperationalReactorsByCountry.aspx>. Acesso em: 11/02/2015.

ISHIGURO, Y. A Energia Nuclear para o Brasil. São Paulo. Makron Books, 2002.

JAY, S.; JONES, C.; SLINN, P.; WOOD, C. Environmental Impact Assessment: Retrospect and prospect. Environmental Impact Assessment Review. Manchester, v. 4, n. 27, 287-300, 2007. 
LAINETTI, P.E.O. Fundamentos de Tecnologia Nuclear - Materiais e ciclo do combustível nuclear - TNM 5788 - Instituto de Pesquisas Energéticas e Nucleares (IPEN/CNEN-SP) - Divisão de Ensino, 2013.

LEAL, L.N. Lula acusa IBAMA de atrasar PAC e diz que fará cobrança dura. OESP, Nacional, $\quad$ p. $\quad$ A4. $\quad$ Disponível $<$ http://pib.socioambiental.org/pt/noticias?id=45957> Acesso em: 23/05/2015.

MACHADO, A.Q. Licenciamento Ambiental: atuação preventiva do estado da luz da constituição da república federativa do Brasil. 2010. Dissertação de (Mestrado) - Pontifícia Universidade Católica do Rio Grande do Sul. Porto Alegre.

MACHADO, M.A.D; MENEZES, V.O; QUEIROZ, C.C; SILVA, D.C.; SAMPAIO, L.J.L.; ALMEIDA, A. Revisão: Radioproteção aplicada à Medicina Nuclear. Revista Brasileira de Física Médica. Natal - RN, v. 4, n. 3, p. 47-51, 2011.

MACHADO, P.A.L. Curso de Direito Ambiental Brasileiro. São Paulo: Ed. Malheiros, 2009.

MARQUES, P. Os deletérios impactos da crise nuclear no Japão. Estudos Avançados. São Paulo, v. 26 n.74, p. 309-312, 2012.

MARTINI, K.M; LIMA, E.S. AUDIÊNCIA PÚBLICA: GARANTIA OU NEGAÇÃO DA CIDADANIA AMBIENTAL? Revista Meio Ambiente e Sustentabilidade. v.9, n.4, p. 191-219, jul/dez. 2015.

MASON, T.E.; GAWNE, T.J.; NAGLER, S.E.; NESTOR, M.B.; CARPENTER, J.M. The early development of neutron diffraction: science in the wings of the Manhattan Project. Acta Crystallographica Section a Foundations of Crystallography. A69, p. 37- 44, 2013.

MILANEZ, J.V; ALMEIDA, R.D.; CARMO, F.S, Energia nuclear socialmente aceitável como solução possível para a demanda energética brasileira. Ciências do Ambiente On-Line. v. 2, n. 1, 2006.

MINISTERIO DE AMBIENTE, VIVIENDA Y DESAROLLO TERRITORIAL. Aspectos jurídicos ambientales para proyectos de generación de energía em Colombia. $\quad$ Bogotá: 2008. Disponível em: < http://www.creg.gov.co/phocadownload/publicaciones/aspectos juridicos ambient ales proy energeticos.pdf> Acesso em: 30/04/2016.

MINISTÉRIO DO MEIO AMBIENTE. Manual de Licenciamento ambiental: guia de procedimento passo a passo. Rio de Janeiro: GMA, 2004. Disponível em: $<$ http://www.mma.gov.br/estruturas/sqa pnla/ arquivos/cart sebrae.pdf $>$. Acesso em: 05/04/2013. 
MINISTÉRIO DO MEIO AMBIENTE. Metodologia de cálculo de compensação ambiental. Disponível em: <http://www.mma.gov.br/areas-protegidas/camarafederal-de-compensacao-ambiental/metodologia-de-calculo-dacompensacao-ambiental> Acesso em: 15/01/2016.

MINISTÉRIO DO MEIO AMBIENTE. Resoluções. Disponível em: $<$ http://www.mma.gov.br/port/conama/res/res97/res23797.html>. Acesso em: 20/12/2015.

OLIVEIRA, L. M. O princípio da participação ambiental no processo de transposição do rio São Francisco. 2007. Dissertação (Mestrado) - Pontifícia Universidade Católica de Minas Gerais, Belo Horizonte.

OLIVEIRA, R.; SANTOS, D.; FERREIRA, D.; COELHO, P.; VEIGA, F. Preparações radiofarmacêuticas e suas aplicações. Rev. Bras. Cienc. Farm. São Paulo, v.42, n.2, p. 151-165, abr./jun. 2006.

OLIVEIRA, R. S; BENEVIDES, C.A; HWANG, S.F., SALVI, R.P.C.; FREITAS, I.M.A.T.R. Radiofarmácia e radiofármacos no Brasil: aspectos sanitários e fabris para a construção de uma linha de produção de radiofármacos PET. Rev. Bras. Cienc. Farm. Recife, v.44, n.2, p. 181-184, abr/jun., 2008.

ÓRBITA. RMB entra na fase de licenciamentos. São Paulo: IPEN, Ano XIII, n. 74, jul/ago. 2014

PALERM, J.R. Public participation in EIA in Hungary: analysis through three case studies. Environ Impact Assessment Review. v. 19, p. 201-220, 1999.

PEDRO, A.F.P. Aspectos legais do licenciamento ambiental e das audiências públicas concernentes à instalação da Usina Nuclear Angra 3. Ambiente Legal. São Paulo, nov. 2014.2 Disponível em: http://www.ambientelegal.com.br/licenciamento-ambiental-de-angra-3-aspectoslegais/ Acesso em: 30/04/2016.

PEDUZZI, P. Peritos reforçam alerta sobre falhas na fiscalização e manutenção de barragens. EBC - Agência Brasil. 2016. Disponível em: <http://agenciabrasil.ebc.com.br/geral/noticia/2016-01/para-abrir-sabadoperitosreforcam-alerta-sobre-falhas-na-fiscalizacao-e>. Acesso em: 09/01/2016.

PIMENTA, D.V.A. Da Europa às Américas: uma breve análise comparativa do procedimento de avaliação de impacto ambiental adotado no Brasil, Estados unidos da américa e Portugal. RIDB, n. 3, p. 1667-1718, 2012.

RANGEL, J. A perereca. O novo inimigo do desenvolvimento segundo Lula. 0 Globo. Rio de Janeiro, 01 mai. 2009. Disponível em: http://ipevs.org.br/blog/?p=509 > Acesso em: 23/05/2015. 
RELATÓRIO DE ATIVIDADES DAS AUDIÊNCIAS PÚBLICAS DE APRESENTAÇÃO E DISCUSSÃO DO RELATÓRIO DE IMPACTO AMBIENTAL RIMA. Usina Termoelétrica de Pampa do Sul (Candiota). Disponível em: $<$ http://licenciamento.ibama.gov.br/Termeletricas/UTE\%20Pampa\%20Sul/UTE\%2 0Pampa\%20Sul\%20-\%20AUDIENCIAS\%20PUBLICAS/10.13\%20\%20Transcric\%C3\%B5es\%20das\%20audiencias/UTE\%20Pampa\%20Sul AP\%2 0Candiota Transcricao.pdf> Acesso em: 30/04/2013.

RELATÓRIO DE IMPACTO AMBIENTAL - RIMA. Reator Multipropósito Brasileiro - RMB. São Paulo, 2013.

ROCHA, L.L. Participação social: A efetividade das audiências públicas em processos de licenciamento ambiental em Minas Gerais. Dissertação (Mestrado) - Universidade Federal de Ouro Preto, Minas Gerais. 2008.

RODRIGUES, G.S.S.C; COLESANTI, M.T.M. Educação ambiental e as novas tecnologias de informação e comunicação. Sociedade \& Natureza. Uberlândia, v. 20, n. 1, p. 51-66, 2008.

RODRíGUEZ, G. A. Las licencias ambientales y su proceso de reglamentación en Colombia. Foro Nacional Ambiental. maio/2011. Disponível em: < http://www.foronacionalambiental.org.co/wp-ontent/uploads/2011/11/AnalisisFNA001.pdf> Acesso em: 01/04/2016.

ROSA, L.P. Geração hidrelétrica, termelétrica e nuclear. Estudos avançados, São Paulo, v. 21, n. 59, p. 39-58, jan/abr., 2007.

ROTEIRO DE AUDIÊNCIA PÚBLICA. Centro de Apoio Operacional Cível e de Defesa da Cidadania, $2009 . \quad$ Disponível em:<http://www.mpes.gov.br/anexos/centros apoio/arquivos/15 21001651611420 12 ROTEIRO\%20PARA\%20REALIZA\%C3\%87\%C3\%830\%20DE\%20AUDI\%C3 \%8ANCIA\%20P\%C3\%9ABLICA.pdf > Acesso em: 26/06/2013.

SANCHEZ, L.E. Avaliação de Impacto Ambiental: Conceitos e Métodos. São Paulo: Oficina de Textos, 2010.

SANTINI, L.A. Tribunal de Contas da União. In: SEMINÁRIO SEGURANÇA NUCLEAR E RADIOLÓGICA, 2011, Brasília. Disponível em: $<$ http://portal2.tcu.gov.br/portal/page/portal/TCU/imprensa/noticias/noticias arquiv os/Luiz\%20Antonio\%20Santini.pdf>. Acesso em: 30/07/2014.

SANTORO, B. Licenciamento ambiental e o atraso do país. Instituto Liberal. Rio de Janeiro, 07 abr. 2014.2 Disponível em: $<$ www.institutoliberal.org.br/blog/licenciamento-ambiente-e-o-atraso-pais/> Acesso em: 10/05/2015. 
SANTOS, F.C. Elaboração de um conjunto de funções críticas de segurança para uma unidade de conversão de hexafluoreto de urânio. 2014. Dissertação (Mestrado) - Universidade Federal do Rio de Janeiro, Rio de Janeiro.

SERRÃO, M.A. Os impactos socioambientais $e$ as medidas mitigadoras/compensatórias no âmbito do licenciamento ambiental federal das atividades marítimas de exploração e produção de petróleo no Brasil. Niterói, RJ, 2011. cap. 1-6, Impactos sociais, ambientais e urbanos das atividades petrolíferas: o caso de Macaé. p. 97-112.

SILVA, C. A. M. Tecnologia dos Reatores Nucleares de Potência e de Pesquisa. In: I SENCIR - SEMANA DE ENGENHARIA NUCLEAR E CIÊNCIAS DA RADIAÇÕES - Escola de Engenharia - UFMG, de 29 a 31 de maio de 2012. Belo Horizonte. Disponível em: <http://www.cctn.nuclear.ufmg.br/wpcontent/uploads/2012/06/Reator Pesq Potencia.pdf>. Acesso em: 08/11/2014.

SILVA, G. Expertise e Participação da População em Contexto de Risco Nuclear: Democracia e Licenciamento Ambiental de Angra 3. Revista de Ciências Sociais, Rio de Janeiro, v. 52, n. 3, p. 771-805, 2009.

SOARES, E. A audiência pública no processo administrativo. Jus Navigandi, Teresina, ano 7, n. 58, 1 ago. 2002.

STEINHAUSER, G.; BRANDL, A.; JOHNSON, T.E.; Comparison of the Chernobyl and Fukushima nuclear accidents: A review of the environmental impacts. Science of the Total Environment. Fort Collins, CO, United States 470-471 (2014) 800817

TAVARES, Odilon A. P. Controlada a energia liberada na fissão nuclear. Rio de Janeiro: Centro Brasileiro de Pesquisas Físicas, 2012. 7 p.

TÉBÉKA, I.R.M.; HALLWASS, F. Radiações Nucleares: Histórico e Aplicação Industrial na Preservação de Alimentos. IN: I CONGRESSO NORTE NORDESTE DE QÚMICA - Universidade Federal de Pernambuco - Departamento de Química Fundamental, 2007.2 Disponível em: $<$ http://annq.org/congresso2007/trabalhos apresentados/T41.pdf >. Acesso em: $08 / 11 / 2014$.

TEIXEIRA, O. P. B. O direito ao meio ambiente ecologicamente equilibrado como direito fundamental. Porto Alegre: Livraria do Advogado, 2006.

TERREMOTO, L.A.A - Fundamentos de Tecnologia Nuclear - Reatores TNR5764 - Instituto de Pesquisas Energéticas e Nucleares (IPEN/CNEN-SP) Divisão de Ensino - Secretaria de Pós-Graduação, 2004. 
THE WOODROW WILSON CENTER. China Environment Fórum, Washington, 2006. Issue 8.

TILLEMAN, W.A. Public Participation in the Environmental Impact Assessment Process: A Comparative Study of Impact Assessment in Canada, the United States and the European Community. Columbia Journal of Transnational Law. p. 339436, 1995.

TRENNEPOHL, N. Manual de Direito Ambiental. Niterói: Editora Impetus, 2010.

UNITED STATES NUCLEAR REGULATORY COMMISSION - U.S.NRC - Boiling Water Reactor. Disponível em: <http://www.nrc.gov/reactors/bwrs.html>. Acesso em: 05/01/2015.

UNITED STATES NUCLEAR REGULATORY COMMISSION - U.S.NRC - New Reactors. Disponível em: <http://www.nrc.gov/reactors/new-reactors.html> Acesso em: 08/07/2016.

UNITED STATES NUCLEAR REGULATORY COMMISSION - U.S.NRC - Public Involvement in Hearings. Disponível em: <http://www.nrc.gov/aboutnrc/regulatory/adjudicatory/hearing.html> Acesso em: 08/07/2016.

VARI, A. Public Perceptions about Equity \& Fairness: Siting Low-Level Radioactive Waste Disposal Facilities in the U.S. and Hungary, Risk: Health, Safety \& Environment, 1996, v. 7, p. 181.

VEIGA, J. E. Perspectiva nuclear pós-Fukushima. Política Externa, São Paulo SP, v.20, n. 1, p. 153-159, jun/ago. 2011.

VEIGA, L. Goiânia Radiological accident: Brazilian experience on risk communication. Stakeholder Involvement and Communication in Remediation Projects, november 12-14, 2012. Disponível em: $<$ http://www.iaea.org/OurWork/ST/NE/NEFW/WTS-

Networks/ENVIRONET/environetfiles/StakeholderWhp-

Denmark2012/Goiania Radiological accident-Risk mngt Veiga2.pdf. $>$ Acesso em: 19/04/2014.

VEROCAI, I. O licenciamento ambiental em outros países. In: SEMINÁRIO LICENCIAMENTO, PROTEÇÃO AMBIENTAL E DESENVOLVIMENTO, São Paulo, Brasil, 29 a 30 de julho de 2004. Disponível em: < http://www.mma.gov.br/estruturas/DAl/ arquivos/iaraverocai2.pdf> Acesso em: 30/03/2016. 
VILLASBÔAS, P.P, A Importância da participação pública no processo de avaliação de impacto ambiental. Estudo de caso do Porto da Barra Ltda., Florianópolis, Santa Catarina. 2003. Tese (Doutorado) - Universidade Federal de Santa Catarina, Florianópolis.

WhatsApp alcança 1 bilhão de usuários. G1, São Paulo, fev. 2016. Disponível em: $<$ http://g1.globo.com/tecnologia/noticia/2016/02/whatsapp-alcanca-1-bilhao-deusuarios.html> Acesso em: 04/04/2016.

WESCHENFELDER, P.N. O direito constitucional de todos ao meio ambiente ecologicamente equilibrado e sua força normativa para a construção de uma cultura de equilíbrio ambiental no Brasil. 2010. Dissertação (Mestrado) Universidade de Caxias do Sul, Rio Grande do Sul.

WHITLOCK, J. The evolution of CANDU fuel cycles and their potential contribution to world peace. $2001 . \quad$ Disponivel em: $<$ http://www.iaea.org/inis/collection/NCLCollectionStore/ Public/33/011/33011302. pdf> Acesso em: 13/02/2015.

XAVIER, A.M.; LIMA, A. G.; VIGNA, C.R.M.; VERBI, F.M.; BORTOLETO, G.G.; GORAIEB, K.; HOLLINGWORTH, C.C.; BUENO, M.I.M.S. Marcos da história da radioatividade e tendências atuais. Química Nova, v. 30, n.1, p.83-91, 2007.

YAMAGUCHI, T. E.; SOUZA, M. C. M. Fança: a construção do direito ambiental em um país desenvolvido. Tópos, v. 5, n. 2, p. 47 - 66, 2011.

ZHOURI, A.L.M. "A Re-volta da Ecologia Política" Conflitos Ambientais no Brasil. Henri Acserald (org.). Revista Ambiente e Sociedade. Campinas, v. 7, n. 2, p. 211213, 2004.

ZHONG, L.; MOL, A. P. J. Participatory environmental governance in China: Public hearings on urban water tariff setting. Journal of Environmental Management. v. 88, n. 4, p. 899-913, 2008. 